UNIVERSIDADE DE SÃO PAULO

ESCOLA DE ENGENHARIA DE SÃO CARLOS

PROGRAMA DE PÓS-GRADUAÇÃO EM CIÊNCIAS DA ENGENHARIA AMBIENTAL

ANÁLISE DE IMPACTOS PLUVIAIS EM SÃO LUÍZ DO PARAITINGA SP/BRASIL

Isabela Taici Lopes Gonçalves Horta

São Carlos 
Isabela Taici Lopes Gonçalves Horta

\section{ANÁLISE DE IMPACTOS PLUVIAIS EM SÃO LUIZ DO PARAITINGA - SP/BRASIL}

Dissertação apresentada à Escola de Engenharia de São Carlos da Universidade de São Paulo para obtenção do título de Mestre em Ciências da Engenharia Ambiental.

Área de Concentração: Ciências da Engenharia Ambiental.

Orientador: Francisco Arthur Silva Vecchia.

São Carlos 
AUTORIZO A REPRODUÇĀO TOTAL OU PARCIAL DESTE TRABALHO, POR QUALQUER MEIO CONVENCIONAL OU ELETRÓNICO, PARA FINS POR ESTUDO E PESQUISA, DESDE QUE CITADA A FONTE.

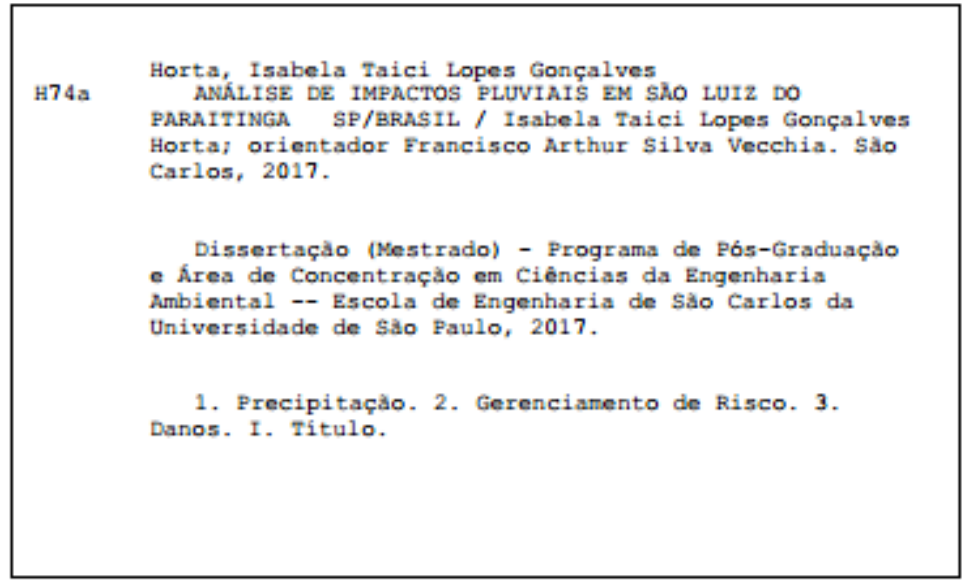




\section{FOLHA DE JULGAMENTO}

Corndidata: I cenciadu e Bachanolo ISABELA TAICI LOPES GONÇALVES HORTA.

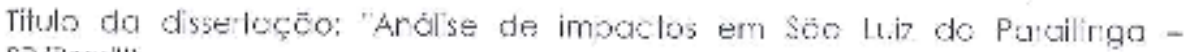
So/Brosil".

Doto do defesa: 27/11/2017.

\section{Comissão Julgadora:}

Prof. Associado Francisca Arthur da Silva Vecchia (Orientador)

Escola de Ergonharia de Sas Corlositesc:

Fro', Dr. Vandoir Bourscheidt

Uriversidade =ederd de Sc̈o Carlosill Fscri

Dra. Geórgĩa Jorge Pellegrina

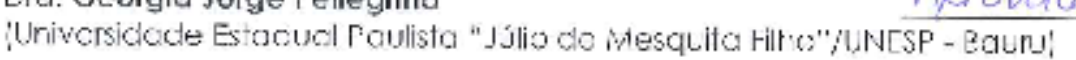

Resultado:

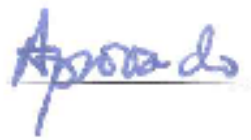

AProvedor

Coordenower do Programo de Pós-Grocuoço em Ciorcos da Engentaria A.mbienial:

PIot. Associado Frederico Fabio Mauad

Presidento da Comissōo de Fós-Gruduacōo:

Prot. Associudo Luís Fernando Costa Alberto 
Dedicado à minha família, amigos, professores orientadores, colegas de trabalho do Núcleo de Climatologia do PPG-SEA e a todos que se debruçam sobre o tema. Em especial, em memória do meu avô Manoel Arraes Lopes Junior.

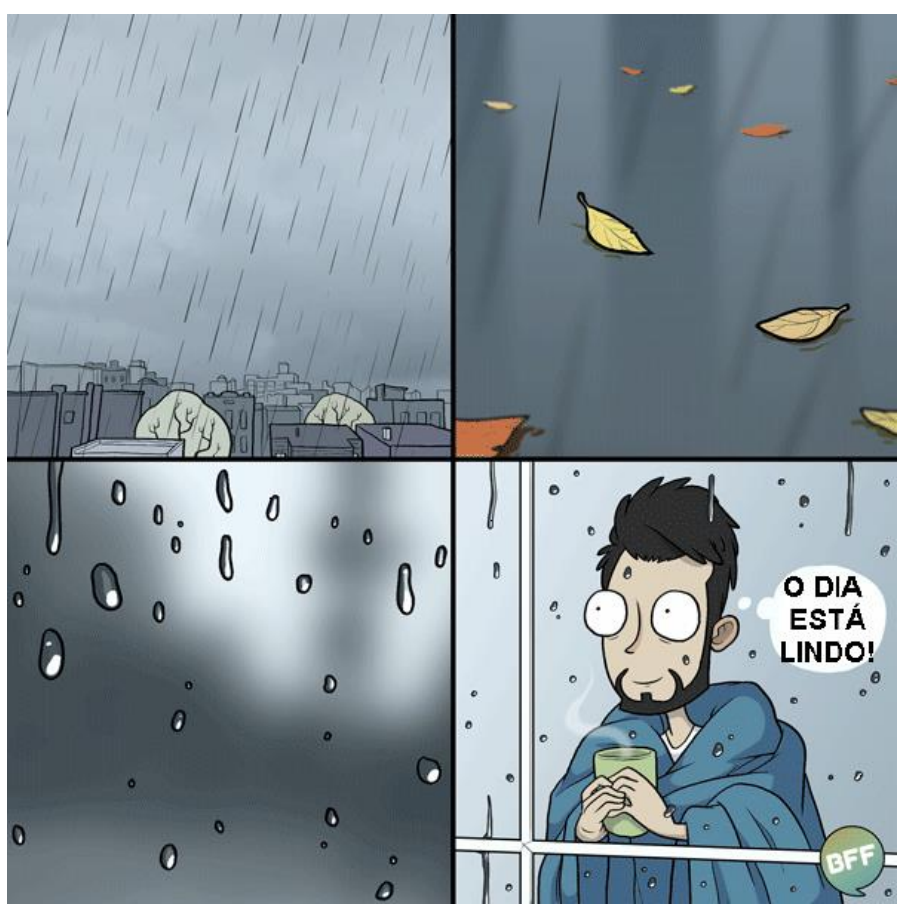




\section{RESUMO}

HORTA, I.T.L.G.Análise de impactos pluviais em São Luiz do Paraitinga SP/Brasil.2017. 107p. Dissertação (Mestrado) - Escola de Engenharia de São Carlos, Universidade de São Paulo, São Carlos, 2017.

Danos em cidades, causados por impactos de precipitações intensas, ocorrem frequentemente e há muito tempo no Brasil, principalmente durante o verão. Isso representa para a sociedade e governo perdas materiais e, muitas vezes, humanas. A recuperação de tais danos depende de fatores como a gravidade do ocorrido, a resiliência da cidade e a capacidade de gerenciamento de sinistros pela parte afetada. A temática sobre gestão e diminuição de riscos e desastres tem sido discutida por diversos países nas convenções sobre mudanças climáticas e sobre desenvolvimento sustentável. Isso significa que os esforços devem ser realizados em todas as escalas. Afinal, num mundo globalizado, o que acontece numa região do planeta importa para a outra região. Com isso, dá-se a importância das pesquisas sobre os impactos de eventos de precipitação, métodos e sistemas de gestão de desastres. Destaca-se o município de São Luiz do Paraitinga, como um exemplo interessante por ter sido afetado por inundações e ser localizado justamente numa região que vem sofrendo modificações na sua paisagem em decorrência das atividades antrópicas, a bacia hidrográfica do Rio Paraíba do Sul. Nesse sentido, a presente pesquisa objetivou analisar impactos pluviais de forma a contribuir com o conhecimento acadêmico sobre tal assunto. A metodologia utilizada teve como objetivo integrar informações estatísticas sobre a precipitação, a descrição dos sistemas atmosféricos produtores de chuva e a identificação dos danos ocorridos, executando uma análise dos diversos fatores contribuintes para o impacto em si. Analisando os dados agrupados em verões os resultados mostraram que os danos ocorreram não somente em eventos de precipitação acima da média, mas também durante as chuvas mais amenas e frequentes; quanto aos sistemas atmosféricos, pôde-se constatar que o principal mecanismo de produção de chuva nos eventos analisados foi pela Zona de Convergência do Atlântico Sul (ZCAS). Os danos mais encontrados na série analisada referem-se a "desabamentos", "rachaduras" e "imóveis danificados".

Palavras - chave: precipitação, gerenciamento de risco, danos. 


\section{ABSTRACT}

Damage to cities, caused by impacts from heavy precipitations, has been frequent in Brazil, especially in summers. It represents material and, sometimes, human losses to both society and the government. The recovery of cities from such damage depends on factors, as severity of the occurrence, cities' resilience, and ability of the affected party to manage risk. The issues of risk and disaster management and mitigation have been discussed in conventions on climate change and sustainable development in several countries, and efforts for decreasing vulnerability and improving resilience must be intensified on all scales. In a globalized world, what occurs in a region of the planet affects another region, therefore, the development of research on the impacts of precipitation events, methods and systems of disaster management is fundamental. São Luiz do Paraitinga - SP/Brazil is an example of a city affected by floods, also because it is located in the Paraíba do Sul River basin, a region that has undergone changes in its landscape due to anthropic activities. This research aimed at the analysis of precipitation impact events in the above-mentioned city towards contributing to the academic knowledge on this subject. The methodology used statistical information on precipitation, description of atmospheric rainfall systems and identification of damages and provided an integrated analysis of the several factors that have contributed to the impact itself. The results show damages occurred not only in above-average precipitation events, but also during milder and frequent rains. Regarding atmospheric systems, the South Atlantic Convergence Zone (SACZ), was the main mechanism of rainfall production in the events analyzed and "landslides", "disruptions" and "danification to buildings" were the damages mostly detected.

Key words: precipitation, risk management, damages. 


\section{Sumário}

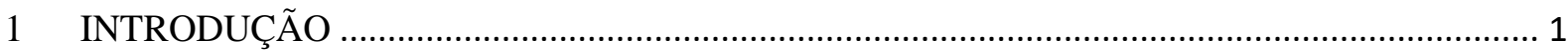

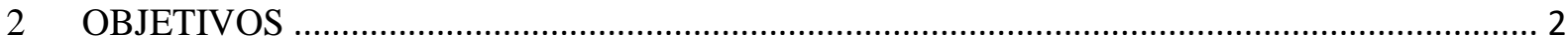

3 REVISÃO BIBLIOGRÁFICA....................................................................................... 3

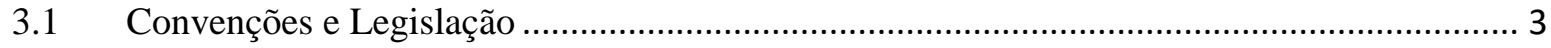

3.2 Conceitos segundo a Secretaria Nacional de Defesa Civil............................................. 5

Conceitos discutidos na Academia................................................................ 8

3.4 Sistemas para gestão do risco e divulgação dos dados ............................................. 11

3.5 Comunicação e memória ................................................................................ 12

Escala e atuação dos sistemas atmosféricos .................................................... 13

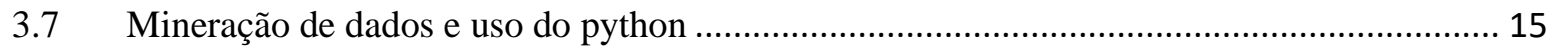

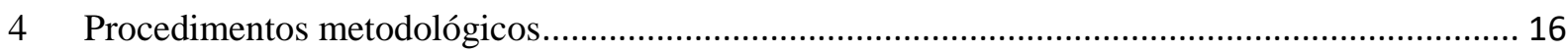

4.1 Banco de Dados de Desastres Naturais ............................................................... 16

Coleta e processamento dos dados de precipitação.................................................... 21

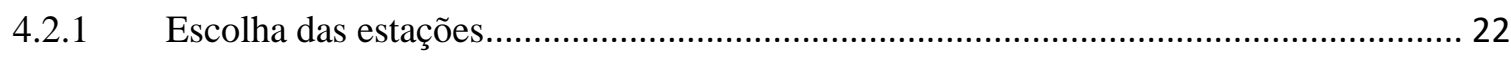

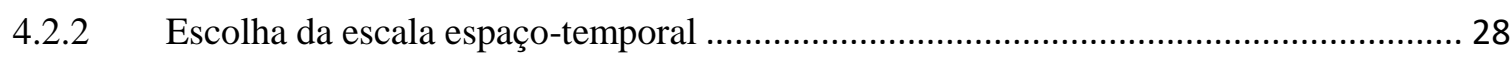

4.2.3 Mensuração das medidas estatísticas dentro da série de 32 verões ............................ 29

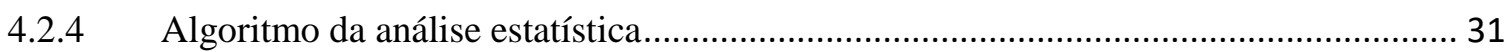

4.3 Identificação e descrição dos sistemas atmosféricos deflagradores do evento ......................33

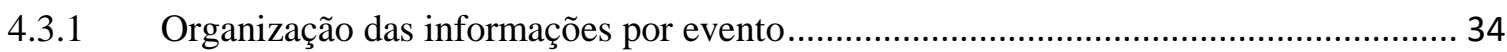

Caracterização da área de estudo ........................................................................ 35

4.4.1 Localização, povoamento e atividades econômicas ............................................... 35

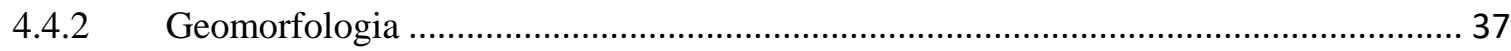

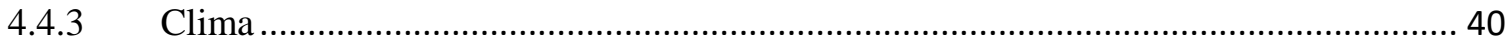

4.4.4 Meio físico e impactos ambientais ........................................................... 40

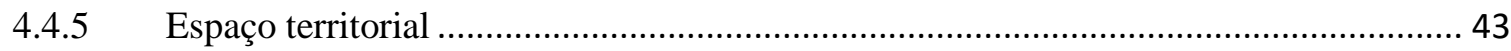

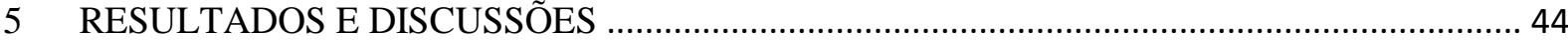

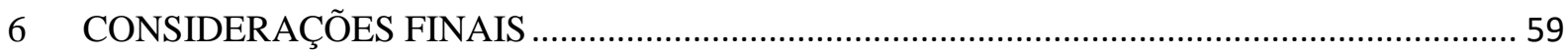

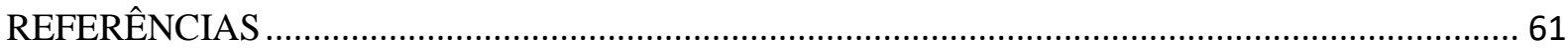

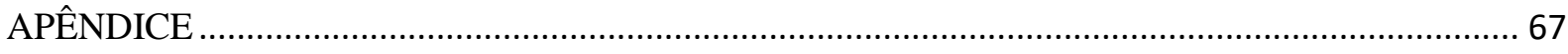

$\begin{array}{ll}\text { ANEXO } & 73\end{array}$ 


\section{LISTA DE FIGURAS}

Figura 1 - Esquema explicativo de Risco, Perigo, Desastre e Vulnerabilidade.

Figura 2. As escalas do movimento atmosférico relativo ao tamanho do fenômeno e sua vida útil.

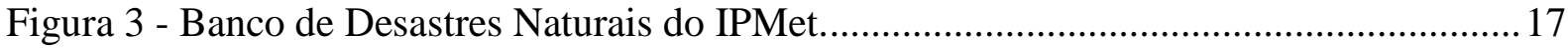

Figura 4 - Layout antigo da plataforma Hidroweb. ............................................................ 21

Figura 5. Diagrama de dispersão entre 02345175 e 02345067 entre os anos 1998 e 1999...... 24

Figura 6. Diagrama de dispersão entre 02345175 e 02345067 entre os anos 2013 e 2014...... 24

Figura 7. Diagrama de dispersão entre 02345017 e 02345065 entre os anos de 2010 - 2011. 25

Figura 8. Diagrama de dispersão entre 02345017 e 02345065 entre 1998 - 1999.

Figura 9. Localização das estações pluviais escolhidas no município de São Luiz do

Paraitinga - SP.

Figura 10. Mapa de localização das estações próximas à área urbana de São Luiz do Paraitinga - SP.

Figura 11. Boxplots de precipitação mensal de 1981 - 2010 da Região 114 .......................... 28

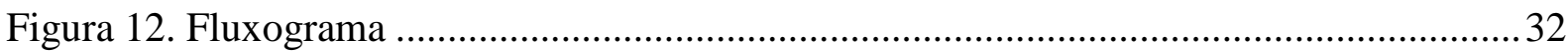

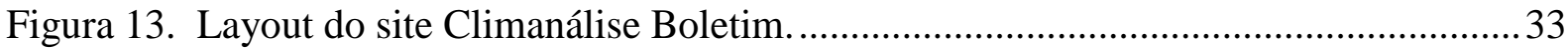

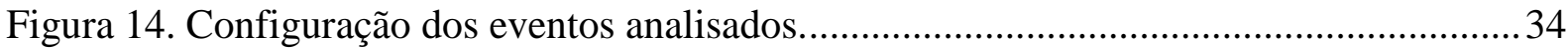

Figura 15. Plantações de eucalipto "emolduram" cenário de construções de arquitetura colonial do centro.

Figura 16. São Luiz do Paraitinga situada no domínio de mares de morros. ............................ 38

Figura 17. Mapa hipsométrico de São Luiz do Paraitinga - SP.............................................. 39

Figura 18. Mapa de declividade do município de São Luiz do Paraitinga - SP.

Figura 19. Mapa da cobertura vegetal e unidades de conservação de São Luiz do Paraitinga SP. 41

Figura 20. Delimitação do município de São Luiz do Paraitinga - SP. ..................................... 42

Figura 21. Funções Urbanas de São Luiz do Paraitinga - SP.................................................. 44 


\section{LISTA DE QUADROS}

Quadro 1. Definição de conceitos relativos à gestão de Riscos e Desastres segundo a

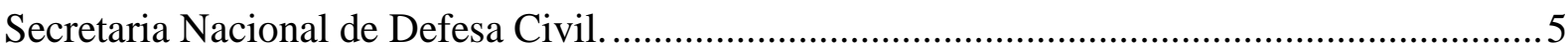

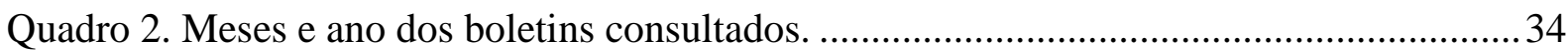

Quadro 3. Evento de impacto pluvial 1 - verão 2003/2004 .....................................................46

Quadro 4. Evento de impacto pluvial 2 - verão 2004/2005 ................................................ 47

Quadro 5. Evento de impacto pluvial 3 - verão 2005/2006................................................. 48

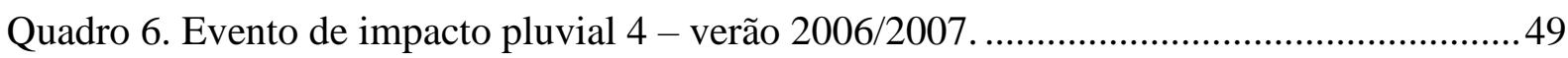

Quadro 7. Evento de impacto pluvial 5 - verão 2007/2008 ...................................................50

Quadro 8. Evento de impacto pluvial 6 - verão 2008/2009 ...................................................51

Quadro 9. Evento de impacto pluvial 7 - verão 2009/2010 .................................................52

Quadro 10. Evento de impacto pluvial 8 - verão 2010-2011 ................................................53

Quadro 11. Evento de impacto pluvial9 - verão 2012/2013.................................................54 


\section{LISTA DE TABELAS}

Tabela 1. Resultado dos registros obtido da consulta ao Banco de Dados de Desastres Naturais 18

Tabela2-Legenda de Danos e Descrição do Fenômeno. Banco de Dados de Desastres Naturais. IPMet. 20

Tabela 3. Estações pluviométricas de São Luíz do Paraitinga - SP. 22

Tabela 4. Ocorrências registradas no Banco de Dados de Desastres Naturais........... 45

Tabela 5. Tipo e frequência de danos na série de impactos analisada. 


\section{INTRODUÇÃ̃o}

O clima é um fator natural regulador da vida na Terra. Seja para a produção de alimentos, para a dispersão ou controle de doenças, para a produção de energia elétrica ou previsão do tempo, a humanidade sempre esteve atento à atuação da atmosfera e a repercussão sobre suas vidas.

Como forma de colaborar para a temática sobre climatologia aplicada a presente pesquisa disserta sobre os impactos da precipitação no município de São Luiz do Paraitinga - SP, escolhido o período de análise entre os anos de 1982 a 2014.

A região da qual pertence o município de São Luiz do Paraitinga vêm sofrendo modificações na paisagem há cerca de dois séculos e meio, em decorrência das atividades econômicas e o próprio desenvolvimento da cidade. Tais modificações na vegetação, relevo e hidrologia em conjunto com a ocorrência de chuvas fortes têm contribuído para o desencadeamento de desastres naturais de origem atmosférica e hidrológica.

Além da ação do homem sobre o meio, outro fator importante é o mecanismo atmosférico produtor de chuvas sob o qual se encontra o município. A área recebe influência da Zona de Convergência do Atlântico Sul o que proporciona chuvas intensas que podem durar dias. Sendo o relevo sobre o qual se situa a cidade um vale, o local fica propício às ocorrências de inundações, alagamentos e desabamento de massa, agravando ainda mais o risco de desastres.

Analisar os impactos deflagrados por chuvas é essencial para o entendimento de desastres naturais no Brasil, e consequentemente sua gestão e diminuição de riscos e vulnerabilidades. Tal tema é de interesse de todos os países e encontra-se em pauta nas conferências mundiais, tratando-se, inclusive, de um desafio maior: o desenvolvimento sustentável. De acordo com Valencio $^{1}$ (2010) apud Marchezini et al (2017) os desastres produzem a disrupção da vida social de milhões de pessoas a cada ano no Brasil. Afinal, como uma população pode se desenvolver se precisar retomar suas vidas "do zero" após perdas materiais e humanas decorrente de desastres naturais?

Outro ponto importante a destacar é que a redução de riscos e vulnerabilidades influencia, também, a economia do país. A ocorrência de desastres pode significar grandes perdas econômicas, desde sua ocorrência até a fase de recuperação. Num estudo sobre avaliação de

\footnotetext{
${ }^{1}$ VALENCIO (2010) - VALENCIO, N. (2010). Sociologia dos Desastres: construções, interfaces e perspectivas no Brasil. Volume II. (N. Valencio, Ed.) Interfaces (1st ed., p. 238). São Carlos: Rima Editora.
} 
perdas e danos Corsi, Azevedo e Gramani (2012) contabilizaram, entre efeitos e impactos em setores sociais, econômicos, ambientais e de infraestrutura, um prejuízo de R \$ 103,63 milhões para o município de São Luiz do Paraitinga após a inundação de 2009-2010. Por outro lado, na medida em que o país se torna mais resiliente aos eventos climáticos, mais confiança ele terá frente aos outros países e possíveis investidores. Sendo assim, faz-se necessário um planejamento de gestão dos riscos e desastres.

O processo de gestão de riscos é complexo e abrange ações de prevenção, resposta e recuperação. Para isso incluem-se etapas de planejamento urbano, monitoramento ambiental, previsão meteorológica, treinamento da defesa civil, campanhas para conscientização ambiental, entre outros. Faz-se necessário então, o trabalho de uma equipe multidisciplinar para conhecer a fundo as características chaves, como por exemplo, a geomorfologia, a climatologia, hidrologia, geologia, uso e ocupação do solo.

Frente à equipe multidisciplinar e a uma população sedenta por informações e necessitada de ajuda, a informação codificada e os sistemas de informação entram como ferramentas importantes para a comunicação entre as partes responsáveis no período antes, durante e após a ocorrência de situações calamitosas.

A integração das informações sobre variabilidade da precipitação, atuação dos sistemas atmosféricos, uso e ocupação do território fazem parte do processo da compreensão e gestão dos desastres e riscos para aumento da resiliência e adaptação dos municípios frente às adversidades climáticas. Um sistema de informações integrado também contribui, inclusive, para a realização de estudos interdisciplinares que objetivam compreender as relações entre a expressão quantitativa e a expressão qualitativa do tema.

\section{OBJETIVOS}

\section{Objetivo Geral}

Analisar os impactos pluviais no Município de São Luiz do Paraitinga - SP.

\section{Objetivos Específicos}

- Identificar os danos a partir das ocorrências registradas pela Defesa Civil e disponíveis no Banco de Dados de Desastres Naturais do IPMet;

- Descrever os sistemas atmosféricos atuantes durante o registro; 
- Reconhecer a variabilidade da precipitação durante a série de 1982 - 2014 em São Luiz do Paraitinga - SP.

\section{REVISÃO BIBLIOGRÁFICA}

Situações calamitosas deflagradas por fenômenos atmosféricos podem ocorrer em qualquer nação ou nicho social. Considerando um mundo globalizado, em que um país depende do outro economicamente, ou para provimento de mão de obra ou recursos naturais, questões como vulnerabilidade, resiliência e, capacidade de gestão do risco e desastres de um determinado local, importa a todos.

De forma a superar e evitar tais calamidades, os governos e organizações de diversos países têm se reunido para compreender melhor os riscos e vulnerabilidades. Pode-se citar como exemplo desse esforço a realização de convenções internacionais, estabelecimento de metas para diminuição de riscos e vulnerabilidades e legislações que regulam e orientam as ações na ocorrência de situações calamitosas. Abaixo enconra-se descrito tais conceitos pertinentes à pesquisa.

\subsection{Convenções e Legislação}

No âmbito mundial podemos citar o Marco de Ação de Hyogo (2005 - 2015) no qual foi gerado um documento que é usado como instrumento de gestão pelos Estados Membros das Nações Unidas, com o objetivo de estabelecer prioridades de ações para a redução de riscos, da vulnerabilidade e aumento da resiliência nas nações entre os anos de 2005 a 2015.

Foram estabelecidas no Marco de Ação de Hyogo as seguintes premissas:

a) fazer com que a redução dos riscos de desastres seja uma prioridade;

b) conhecer o risco e tomar medidas;

c) desenvolver uma maior compreensão e conscientização;

d) reduzir o risco;

e) estar preparado e pronto para atuar.

Sucessivamente ao Marco de Ação de Hyogo ocorreu o Marco de Sendai para a Redução do Risco de Desastres (2015 - 2030), evento no mesmo formato que o anterior no qual líderes participantes do Comitê das Nações Unidas produziram outro documento para ser utilizado também como instrumento de governança assinado pelos Estados Membros no qual as prioridades foram reformuladas e apresentadas da seguinte forma: 

a) compreensão do risco de desastres;
b) fortalecimento da gestão do risco de desastres;
c) investir na redução do risco de desastres para a resiliência;
d) aumentar a preparação para desastres para uma resposta eficaz e para "reconstruir melhor" em recuperação, reabilitação e reconstrução.

É importante ressaltar que esses documentos podem ser usados como guia de governança pelos países membros das nações unidas bem como pelos países não membros.

No âmbito nacional brasileiro temos, na base legal, a Lei 12.608, de 10 de abril de 2012 a qual institui a Política Nacional de Proteção e Defesa Civil (PNPDEC) que dispõe sobre o Sistema Nacional de Proteção e Defesa Civil (SINPDEC) e o Conselho Nacional de Proteção e Defesa Civil (CONPDEC) o qual, de uma forma mais operacional que as convenções mundiais, autorizou a criação de sistema de informações e monitoramento de desastres.

Diante da temática complexa como a adaptação aos eventos meteorológicos e climáticos a PNPDEC demanda ações pensadas por profissionais de diversas áreas, incluindo tecnologia, planejamento, saúde, educação, entre outras. De acordo com o texto:

\begin{abstract}
A PNPDEC deve integrar-se às políticas de ordenamento territorial, desenvolvimento urbano, saúde, meio ambiente, mudanças climáticas, gestão de recursos hídricos, geologia, infraestrutura, educação, ciência e tecnologia e às demais políticas setoriais, tendo em vista a promoção do desenvolvimento sustentável (BRASIL, Lei 12.608, 10 de abril de 2012).
\end{abstract}

Além da PNPDEC, no âmbito de ação das prefeituras municipais existe o Programa "Cidades Resilientes" no qual as cidades devem se preparar para enfrentar eventos adversos, isso deve ser feito por meio do planejamento, zoneamento e obras de interesse público. A ONU lançou em 2012 um guia para gestores públicos locais, intitulado "Como construir cidades mais resilientes", no qual aponta e descreve estratégias que podem ser adotadas pelos governantes locais interessados na redução dos riscos aos desastres e aumento da resiliência de seu município.

Esse guia enfatiza 10 passos prioritários para a construção de cidades resilientes a desastres, são eles (COMO CONSTRUIR CIDADES MAIS RESILIENTES, 2012, 98 p.):

a) Organizar e melhorar o Quadro Institucional e Administrativo;

b) Reservar recursos e financiamentos direcionados para a Redução de Riscos aos Desastres;

c) Conhecer os Riscos: Avaliação de Risco e Ameaça Múltipla;

d) Proteger e Melhorar a Resiliência de Infraestrutura; 
e) Proteger os Serviços Essenciais: Educação e Saúde;

f) Elaboração de Regulamentos e Planos de Uso e Ocupação do Solo;

g) Realizar o treinamento, educação e sensibilização pública;

h) Realizar a proteção ambiental e fortalecimento dos ecossistemas;

i) Garantir a preparação, sistemas de alerta e alarme, e resposta efetivos;

j) Assegurar as necessidades dos sobreviventes no centro da reconstrução e a reconstrução mais segura.

Tais premissas e determinações não devem ser discutidas somente no âmbito legislativo, mas executivo também. A Secretaria Nacional de Defesa Civil, por exemplo, tem publicado junto com a Universidade Federal de Santa Catarina (UFSC) documentos como planos de ação pósdesastres e planos para redução de riscos e desastres; junto com eles conceitos relativos a esta temática.

\subsection{Conceitos segundo a Secretaria Nacional de Defesa Civil}

Como forma de sistematizar, quantificar e operacionalizar as questões relacionadas às ocorrências de sinistros, a Defesa Civil, em concordância com a PNPDEC estabelece uma conceituação objetiva dos termos relativos. Dessa forma os municípios podem emitir relatórios específicos sobre a situação pós-desastre, e então receber ajuda de outros órgãos para o restabelecimento da rotina do município. A seguir o Quadro 1 reúne tais conceitos:

Quadro 1. Definição de conceitos relativos à gestão de Riscos e Desastres segundo a Secretaria Nacional de Defesa Civil.

\begin{tabular}{l}
\hline Desastre \\
\hline Resultado de eventos adversos, naturais ou provocados pelo homem, sobre um \\
ecossistema vulnerável, causando danos humanos, materiais e ambientais e \\
consequentes prejuízos econômicos e sociais. \\
A intensidade de um desastre depende da interação entre a magnitude do evento \\
adverso e a vulnerabilidade do sistema e é quantificada em função de danos e \\
prejuízos. \\
\hline Risco \\
Medida de danos ou prejuízos potenciais, expressa em termos de probabilidade \\
estatística de ocorrência e de intensidade ou grandeza das consequências previsíveis.
\end{tabular}



Relação existente entre a probabilidade de que uma ameaça de evento adverso ou acidente determinados se concretize, com o grau de vulnerabilidade do sistema receptor a seus efeitos.

\section{Dano}

Medida que define a intensidade ou severidade da lesão resultante de um acidente ou evento adverso.

Perda humana, material ou ambiental, física ou funcional, que pode resultar, caso seja perdido o controle sobre o risco.

Intensidade das perdas humanas, materiais ou ambientais, induzidas às pessoas, comunidades, instituições, instalações e/ou ecossistemas, como consequência de um desastre. Podem ser classificados em: humanos, materiais e ambientais. Danos humanos referem-se à pessoa em si, tais como: desalojamento, desaparecimento, ferimentos, mortes, incapacitação, entre outros. Danos materiais referem-se à estruturas do local, sejam elas privadas ou públicas, importando a sua discriminação, tais como: abastecimento de água e energia interrompida, calçadas e ruas interditadas, entre outros. Danos ambientais referem-se às pressões exercidas sobre os recursos naturais, tais como: poluição e contaminação do ar, solo ou água, degradação e perda do solo, redução da biodiversidade da flora e fauna, entre outros.

\section{Impacto}

Momento em que o evento adverso atua em sua plenitude máxima.

\section{Vulnerabilidade}

Condição intrínseca ao corpo ou sistema receptor que, em interação com a magnitude do evento ou acidente, caracteriza os efeitos adversos, medidos em termos de intensidade dos danos prováveis.

Relação existente entre a magnitude da ameaça, caso ela se concretize, e a intensidade do dano consequente.

Ameaça

Estimativa de ocorrência e magnitude de um evento adverso, expressa em termos de probabilidade estatística de concretização do evento e da provável magnitude de sua manifestação.

Segurança

Estado de confiança, individual ou coletivo, baseado no conhecimento e no emprego de normas de proteção e na convicção de que os riscos de desastres foram reduzidos, 
em virtude de terem sido adotadas medidas minimizadoras.

\section{Defesa Civil}

Conjunto de ações preventivas, de socorro, assistenciais e reconstrutivas, destinadas a evitar ou minimizar os desastres, preservar o moral da população e restabelecer a normalidade social.

\section{Situação de Emergência}

Reconhecimento legal pelo poder público de situação anormal, provocada por desastre, causando danos suportáveis à comunidade afetada.

\section{Estado de Calamidade Pública}

Reconhecimento legal pelo poder público de situação anormal, provocada por desastre, causando sérios danos à comunidade afetada, inclusive à incolumidade ou à vida de seus integrantes.

\section{Desenvolvimento Sustentável}

É aquele que atende às necessidades do presente, sem comprometer a possibilidade das gerações futuras atenderem as suas próprias necessidades.

É o uso e gestão responsáveis dos recursos naturais, de modo a propiciar maior benefício às gerações atuais, mantendo, porém, suas potencialidades para atender às necessidades e aspirações das gerações futuras, pelo maior espaço de tempo possível.

Fonte: Adaptado de CEPED (2012).

Ainda no sentido de sistematizar e otimizar o processo de avaliação dos danos após o desastre e dentro da mesma instrução normativa da PNPDEC, a Defesa Civil desenvolveu e está utilizando o sistema de Codificação Brasileira de Desastres (COBRADE) para classificar a tipologia do desastre ocorrido e preencher o Formulário de Informações do Desastre (FIDE).

Tal formulário deverá conter informações necessárias para a caracterização do desastre, incluindo a estimativa de danos humanos, materiais, ambientais, prejuízos econômicos e os serviços essenciais prejudicados. O FIDE, por sua vez, é informatizado e disponibilizado no Sistema Integrado de Informações sobre Desastres (S2ID), (FURTADO et al., 2012).

O COBRADE permite a classificação dos desastres em Naturais e Tecnológicos e, dentro desses há os grupos, subgrupos, tipo, subtipo, a definição, o número COBRADE e a simbologia. A partir dessa classificação é possível mensurar melhor os danos e as medidas de 
mitigação necessárias a serem tomadas. $\mathrm{O}$ anexo 1 disponibiliza o documento oficial do COBRADE.

Já na área acadêmica, como parte do aprimoramento das teorias e metodologias sobre riscos e desastres naturais, autores das mais diversas áreas têm se debruçado nesse assunto. O subcapítulo a seguir apresenta tais conceitos utilizados na presente pesquisa.

\subsection{Conceitos discutidos na Academia}

Na Academia a temática de desastres e gestão do risco vem sendo discutida também por autores como Busch (2008); Marcelino (2008); Mattedi e Butzke (2001); Nunes (2009); Pellegrina (2011).

Nunes (2009) afirma que os conceitos de risco, vulnerabilidade e desastre estão relacionados um ao outro de forma que "risco" é a probabilidade de consequências danosas na interação entre um evento deflagrador, natural ou não, e a situação de vulnerabilidade da população. Sendo ele a probabilidade, o risco pode ser assumido, estimado, avaliado, diminuído ou aumentado. Se combatida a vulnerabilidade, pode-se diminuir o risco.

A vulnerabilidade, por sua vez, revela o quanto a sociedade é capaz ou não de superar os efeitos adversos da sua exposição aos sinistros com rupturas na rotina e impactos socioambientais.

Já o desastre ocorre quando a capacidade material da sociedade atingida em amortecer os efeitos negativos de um sinistro é superada, ocasionando assim, a "ruptura das funcionalidades do território" (NUNES, 2009). Demonstrando maior gravidade no que concerne ao desastre a autora diz ser o ápice de um processo que, quando ocorre, revela o desequilíbrio contínuo entre as forças naturais contrariamente às forças sociais. Suas consequências inclusive podem estar mais relacionadas à ocupação do espaço pela sociedade do que pelo evento físico em si.

Marcelino (2008) define risco, perigo, desastre e vulnerabilidade como uma causalidade de eventos. Faz parte da dinâmica da natureza ocorrer diversos tipos de fenômenos, sendo esses monitorados ou não pelo homem. De acordo com o autor, nossa preocupação se inicia quando tais fenômenos ocorrem ou se deslocam em direção a um sistema social. A partir daí tem-se uma situação de perigo.

O autor ainda descreve duas possibilidades de sucessão. Uma seria esse evento causar impactos de difícil superação pelas comunidades afetadas, como a falta de fornecimento de água, luz, telefonia, dificuldade de provimento de alimentos e interrupção da coleta de lixo e 
rede de esgoto. $\mathrm{Ou}$, em segundo caso, causar impactos mínimos ou nulos. Na ocorrência da primeira possibilidade, está estabelecido o desastre. Na ocorrência da segunda, tem-se apenas o evento natural. O esquema a seguir (Figura 1) ilustra tais conceitos onde o risco é a probabilidade entre o perigo e o desastre:

Figura 1 - Esquema explicativo de Risco, Perigo, Desastre e Vulnerabilidade.

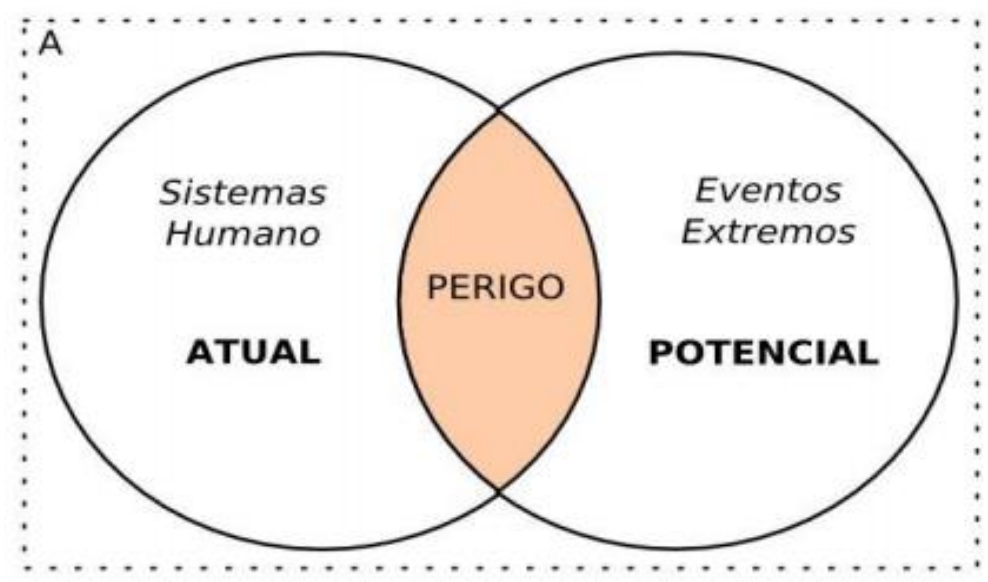

\section{RISCO}

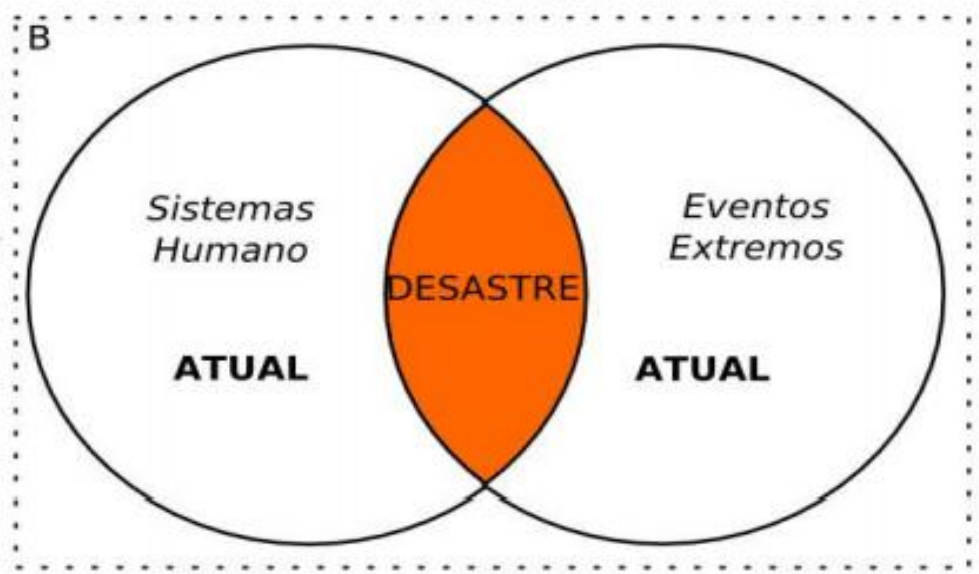

Fonte: Marcelino, 2008.

Mattedi e Butzke (2001) num estudo sobre a relação entre o social e o natural durante eventos de impacto afirmam que, nessas situações de crise, ocorre uma "revelação" de como a sociedade interage com o ambiente natural, sendo, portanto, um indicador de sustentabilidade.

Para os autores, informações como: formas de organização social durante os impactos, percepções do risco das populações atingidas, capacidade de auto-organização e o aprendizado dos atores sociais, adequação das políticas públicas já implementadas, os conflitos de interesses em períodos de crise, os efeitos sobre a dinâmica de desenvolvimento 
socioeconômico; são indispensáveis para a formulação e implantação de medidas de superação aos eventos calamitosos.

Mattedi e Butzke (2001) ainda discorrem sobre duas teorias de estudo dessa temática. São elas "teoria dos Hazards" e "teoria dos Desastres". A primeira foi desenvolvida do ponto de vista geográfico e enfatiza os aspectos físicos das perdas provocadas pelos eventos. Enquanto que a segunda, desenvolvida por sociólogos, enfatiza os aspectos sociais desses eventos. Demonstrando assim, a relação de interdependência quando se tenta explicar eventos naturais deflagradores de impactos sociais.

Finalizando o estudo, os autores afirmam que "os impactos não são um elemento do ambiente, mas são construídos na confluência da sociedade, ambiente e tecnologia” (p. 15). No entanto, “estudos mostraram que as pessoas que vivem em áreas de risco percebem os eventos como uma ameaça, contudo não atribuem seus impactos a fatores sociais" (p.7), o que evidencia a necessidade de se educar a população sobre os fatores deflagradores de desastres.

Como exemplo de aplicação de tais conceitos pode-se citar o trabalho de Busch (2008), no qual discorre sobre as perdas causadas por eventos de precipitação intensa em comunidades da Alemanha. A proposta do estudo foi colaborar para as bases de um instrumento que calcula o risco desses eventos para as companhias de seguro.

Para isso, esteve disponível um conjunto de dados quantitativos de precipitação, contemplando uma série de mais de 86 anos, além de um background sobre medidas estatísticas encontrado no "German KOSTRA Atlas" no qual tentou encontrar uma tendência de tempo de retorno para tais eventos. As informações sobre as condições atmosféricas foram extraídas de imagens de radar fornecidas pelo Serviço de tempo atmosférico alemão (GermanWeather Service), a partir de tais imagens foi possível inferir a quantidade de chuva em milímetros.

Neste estudo sobre riscos em comunidades alemãs, os eventos foram analisados de acordo com a sua dimensão no espaço e sua frequência de ocorrência. O autor também consultou os registros de chamadas de emergência de 16 departamentos do Corpo de Bombeiros desde o ano de 1998 até 2006 a fim de relacionar as ocorrências registradas com os padrões atmosféricos. Outra fonte para seu estudo foram quatro companhias de seguro, as quais se disponibilizaram a responder um questionário sobre os gastos com o seguro por inundações bruscas e ressacas e a forma como o adicional no seguro era calculado. 


\subsection{Sistemas para gestão do risco e divulgação dos dados}

Uma vez que os desastres são, por definição, um acontecimento que pode atrasar o desenvolvimento de uma sociedade, o seu gerenciamento corresponde à maior resiliência e estabilidade de um país. Em decorrência disso, as ferramentas que auxiliam esse gerenciamento são de suma importância.

Os bancos de dados que organizam e disponibilizam as informações necessárias para o gerenciamento dos desastres são exemplos dessas ferramentas.

São exemplos de banco de dados: The International Disaster Database (EM - DAT) que abrange dados de diversos países, o Sistema Integrado de Informações sobre Desastres da Defesa Civil (S2ID) que abrange dados do Brasil e o Banco de Dados de Desastres Naturais do IPMet, que abrange dados de municípios do estado de São Paulo e Paraná.

O EM - DAT é um banco de dados sobre desastres, gerenciado pelo Centro de Pesquisa de Epidemias de Desastres (CRED), da Universidade Católica de Louvain em colaboração com diversas instituições, principalmente a Federação Internacional da Cruz Vermelha e Sociedades em Crescimento (IFRC), a Secretaria de Estratégias Internacionais para Redução de Risco (UNISDR) e a Agência Estadunidense de Desenvolvimento Internacional (USAID), que colaboram com estudos estatísticos e provimento de informações sobre os desastres em alcance global.

Em sua metodologia de classificação de desastres há uma divisão com cinco níveis, são eles: "grupo de desastre", "subgrupo de desastre", "tipo principal de desastre", "subtipo de desastre" e "sub sub tipo de desastre", o apêndice 2 refere-se a tais níveis mais detalhados. Além de que para o evento ser considerado um desastre é preciso que pelo menos um dos seguintes critérios seja satisfeito (CRED, 2017):

- 10 ou mais pessoas reportadas mortas;

- 100 ou mais pessoas reportadas afetadas;

- Declaração de estado de emergência;

- Chamado de ajuda internacional.

O S2ID é uma plataforma de banco de dados brasileira gerenciada pelo Ministério da Integração Nacional a qual é composta por produtos da Secretaria Nacional de Proteção e Defesa Civil (Sedec) e pelos resultados de pesquisas realizadas pelo Centro Universitário de 
Estudos e Pesquisas sobre Desastres de Santa Catarina (CEPED/UFSC) objetivando o gerenciamento de riscos e desastres.

Essa plataforma é utilizada, principalmente para a solicitação do Reconhecimento Federal de Situação de Emergência e Estado de Calamidade Pública e para o registro de danos e prejuízos causados por desastres, ou seja, os principais usuários são autoridades locais que reportam as ocorrências dos desastres para o governo federal (BRASIL, 2017).

O Banco de Dados de Desastres Naturais do IPMet foi desenvolvido como o objetivo de reunir informações das ocorrências registradas na Defesa Civil relativas aos desastres naturais de origem atmosférica. Os jornais locais e nacionais também foram utilizados como fonte de informação.

O banco de dados compreende o período de 1967 até os dias atuais reúne informações sobre a data de ocorrência, o horário, o tipo de evento meteorológico, seu tempo de duração e os danos causados. A busca pode ser feita a partir da seleção dos seguintes critérios: "Data Início", "Data fim", "Fenômeno", "Dano", "Estado" e/ou "Cidade”. Tal ferramenta gera um inventário dos desastres possibilitando assim melhor análise sobre os riscos, as vulnerabilidades, os eventos deflagradores e seus impactos (PELLEGRINA, 2011).

\subsection{Comunicação e memória}

Além dos bancos de dados que disponibilizam informações sobre os desastres naturais, outra ferramenta tem se mostrado eficaz no processo de gerenciamento de riscos e desastres: a comunicação. A comunicação sobre os riscos e desastres realizada pelas autoridades direcionada para a população afetada, têm se mostrado mais eficaz para a gestão de tais situações do que a omissão dos fatos ocorridos. No entanto, deve-se considerar que, uma vez que essas informações são de interesse a diversas pessoas, ainda existe a necessidade de determinar melhor os conceitos e as classificações dos riscos e desastres de forma a evitar dúvidas durante o processo de comunicação (SORIANO et al., 2016).

A comunicação faz chegar aos ouvidos do cidadão informações sobre os riscos que esse está submetido. Enquanto que a pesquisa, a compilação e a publicação sobre os desastres naturais pretende gravar na memória do cidadão e autoridades as condições tais pessoas estiveram submetidas no passado.

Tendo em vista isso, foi realizado e publicado o Atlas Brasileiro de Desastres Naturais, documento no qual reúne informações sobre os Desastres Naturais e seus danos no país todo 
entre os anos de 1991 a 2010. [...] "É a valorização da história e seus registros que irá contribuir para que o país consolide sua política nacional de defesa civil e suas ações de redução de riscos de desastres" (ATLAS BRASILEIRO DE DESASTRES NATURAIS, 2013).

Como conclusão do Atlas, na análise dos tipos de desastres naturais ocorridos no estado de São Paulo ao longo de 22 anos, têm-se como constante as ocorrências de enxurradas e inundações. $\mathrm{O}$ documento afirma que:

O modelo de planejamento e gestão dos recursos hídricos, assim como a estruturação da rede de drenagem urbana e os planos de ação e prevenção podem ajudar a amenizar o impacto gerado por esses eventos no município ou região atingida. É necessário compreender que a recorrência dessas tipologias de desastres não é proveniente apenas de fatores climáticos e meteorológicos, mas também do resultado de um conjunto de elementos naturais ou antrópicos, como a falta de planejamento nas cidades, que resulta frequentemente na ocupação de áreas de risco e com total carência de infraestrutura urbana (ATLAS BRASILEIRO DE DESASTRES NATURAIS, 2013, p. 141).

No caso de São Luiz do Paraitinga um exemplo de resgate e conservação da memória é o sítio eletrônico do Museu de História e Arte Regional de São Luiz do Paraitinga (MHAR), alimentado e gerenciado pela Faculdade de Arquitetura, Artes e Comunicação da Universidade Estadual Paulista "Júlio de Mesquita Filho" (UNESP) onde são arquivados acervos audiovisuais, iconográficos multimídias e textuais relativos ao município e da região do Alto Rio Paraíba do Sul.

É importante mencionar que as informações específicas sobre a recuperação do município pós enchente de 2009/2010 são advindas das pesquisas do "Programa Unesp para o Desenvolvimento Sustentável de São Luiz do Paraitinga”, um projeto de extensão da UNESP de Bauru e Araraquara que objetivou auxiliar o município no planejamento e obras de reconstrução pós enchente de 2009/2010 em parceria com a Prefeitura de São Luiz do Paraitinga.

Em se tratando de eventos atmosféricos deflagradores de desastres, são indispensáveis o conhecimento das séries históricas dos elementos climáticos bem como dos mecanismos que geram as condições climáticas, ou seja, não somente a história dos impactos na cidade, mas também a memória sobre os valores de precipitação devem ser conservadas. Pensando nisso foi realizado o levantamento bibliográfico sobre tais aspectos da atmosfera.

\subsection{Escala e atuação dos sistemas atmosféricos}


A atmosfera como sistema dinâmico oscila tanto no tempo como no espaço, apresentando também diversas escalas de atuação na intensidade de um evento.

Os sistemas atmosféricos podem abranger desde pequenas áreas em metros até quilômetros de extensão. Na Figura 2, podem-se observar as escalas de atuação desses no tempo e no espaço. O gráfico mostra em sua abscissa a abrangência dos processos atmosféricos em metros e, no eixo das ordenadas a duração.

Figura 2. As escalas do movimento atmosférico relativo ao tamanho do fenômeno e sua vida útil.

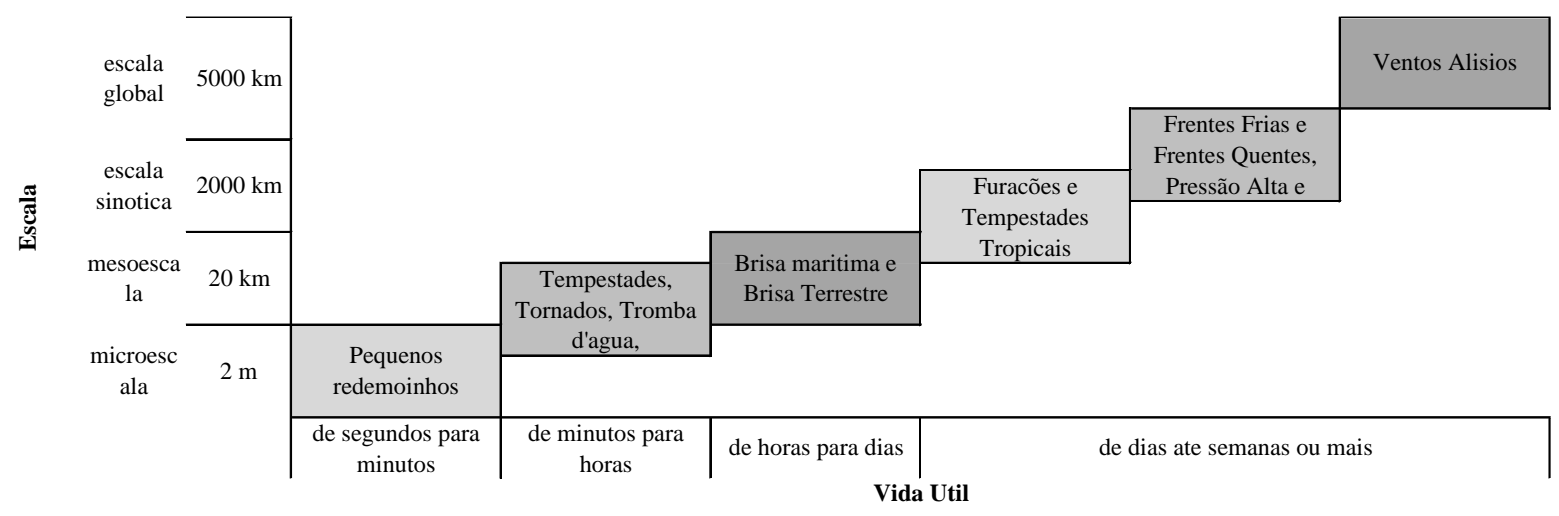

Fonte: Adaptado de Ambrizzi (2014).

A dinâmica atmosférica apresenta certo ritmo que se manifesta numa sucessão habitual dos tipos de tempo. Além da tendência existem aqueles eventos excepcionais, os quais embora esporádicos são os que verdadeiramente impactam a vida no planeta, uma vez que a população não esteja preparada para tais. Eventos extremos são aqueles que, em termos meteorológicos ou climáticos, apresentam grandes desvios da média e podem ocorrer com uma frequência de dias ou milênios (MONTEIRO, 1991).

Sobre os principais sistemas produtores de chuva na região abordada, Ganet al. ${ }^{2}$ (2004) apud QUADRO; PEZZI; ROSA, (2006) citam a Zona de Convergência do Atlântico Sul como extremamente relacionada com o Sistema de Monção da América do Sul causando fortes chuvas no sudeste brasileiro. Esses dois sistemas atmosféricos são os responsáveis pelas precipitações nos meses de primavera e verão sobre a América do Sul. Em porcentagem, os autores afirmam que $50 \%$ da precipitação anual desta área ocorrem entre os meses de dezembro a fevereiro, e cerca de $90 \%$ entre os meses de outubro a abril.

\footnotetext{
${ }^{2}$ GAN et al. (2004) - GAN, A. M., KOUSKY, E. V., ROPELEWSKI, F. C. The South America Monsoon Circulation ad Its Relationship to Rainfall over West-Central Brazil. American MeteorologicalSociety, v. 17, p. 47-66, 2004.
} 
Além das características físicas dos sistemas produtores de chuva, é importante mensurar a quantidade de precipitação dentro de uma série de dados para que se reconheçam as tendências, e os desvios.

\subsection{Mineração de dados e uso do python}

A mineração dos dados ou, prospecção dos dados, é uma das etapas mais importantes dentro de um estudo científico (FORBELLONE, 2005). Especialmente em climatologia, antes de inferir qualquer resultado ou conclusão de uma pesquisa, é preciso organizar os dados, verificar sua consistência, aplicar medidas estatísticas e reconhecer padrões.

De acordo com a Organização Meteorológica Mundial, é necessário considerar uma série de no mínimo 30 anos para poder expressar uma representatividade climática de alguma variável, como por exemplo, a precipitação. Em decorrência do grande volume de dados é preciso buscar técnicas e tecnologias que permitem o processamento desses.

O processamento de dados inclui elaborar, corrigir e reproduzir um raciocínio lógico, quase sempre complexo; para isso a Computação Científica e suas ferramentas auxiliam na otimização dessa etapa.

De acordo com Coelho (2007) a Computação Científica "É uma área de conhecimento que envolve a utilização de ferramentas computacionais para a solução de problemas científicos em áreas da ciência não necessariamente ligadas à disciplina da computação”. Nesse âmbito estão disponíveis diversos "ambientes" para o processamento de dados como o Excel, Bioestat, R, MATLAB, Enthought Canopy, entre outros.

Diferente dos dois primeiros os demais possibilitam o pesquisador gerar um script das ações realizadas. Downey (2012) esclarece o script como um código com as ações que o pesquisador deseja realizar armazenado num documento que, quando executado pelo “intérprete" do "ambiente", retorna os resultados das funções contidas no código.

A vantagem de se ter um script é a possibilidade de consultá-lo para verificar o raciocínio que foi construído e corrigir possíveis erros, ou seja, ajustar o código de acordo com os objetivos da pesquisa sem precisar repetir todas as operações manualmente.

O uso do script permite inclusive, o processamento de funções repetitivas ao longo de extensa série de dados. Isso significa grande economia de tempo e esforços para o pesquisador. Ainda de acordo com Downey (2012, p.64, tradução da autora): “Computadores são frequentemente 
usados para automatizar tarefas repetitivas. Repetir tarefas idênticas ou similares sem cometer erros é algo que computadores fazem muito bem, e as pessoas fazem muito mal".

O python, linguagem escolhida para o processamento dos dados de precipitação da presente pesquisa, é considerada uma linguagem de "alto nível". Lin (2012) enumera as vantagens do python para as ciências atmosféricas: em comparação com as outras linguagens o python apresenta fácil leitura e escrita; não é preciso manipular um compilador ou vinculador; a orientação ao objeto faz o código mais robusto; a linguagem foi projetada com uma estrutura de gerenciamento de variáveis e funções que evita conflito entre essas; e, por fim, o fato da linguagem ser "código aberto" e ser utilizado por companhias e centros de pesquisa significa que os mais diversos códigos em python serão disponibilizados para qualquer usuário.

\section{Procedimentos metodológicos}

Com base na bibliografia consultada e, tendo em vista a interdisciplinaridade da temática, a metodologia utilizada considera os aspectos quantitativos do volume precipitado no município de São Luiz do Paraitinga, as ocorrências registradas na Defesa Civil e a descrição dos sistemas atmosféricos atuantes para então, realizar a análise dos impactos. Dessa forma as etapas podem ser elencadas da seguinte maneira:

- Consulta ao Banco de Dados de Desastres Naturais do IPMet;

- Coleta dos dados no Hidroweb e processamento pelo Canopy;

- Identificação e descrição dos sistemas atmosféricos deflagradores do evento;

- Organização das informações por evento;

- Interpretação dos resultados.

\subsection{Banco de Dados de Desastres Naturais}

Para a identificação e análise dos impactos da precipitação foi utilizado o Banco de Dados de Desastres Naturais do IPMet - Centro de Meteorologia de Bauru. Como explicitado no capítulo "Revisão Bibliográfica" esse Banco de Dados é uma fonte que concentra informações sobre o fenômeno deflagrador do impacto, os danos causados, a data de ocorrência e a localização da ocorrência. Os critérios utilizados nessa pesquisa foram: 01/01/1982 para "Data Início", 31/12/2014 para "Data Fim", todos para "Fenômeno", todos 
para "Danos", São Paulo para "Estado" e Paraitinga para "Cidade". O documento gerado em formato .txt contém todos os registros disponíveis dentro dos critérios selecionados, as ocorrências aparecem codificadas e por isso o documento do download vem com a legenda referente. A leitura desses dados foi realizada a partir do software Microsoft Excel 2013.

A Figura 3 mostra o layout da página do IPMet, a Tabela 1 e 2 mostra os resultados obtidos da consulta, bem como a legenda dos códigos utilizados para o campo "fenômeno" e "ocorrência":

Figura 3 - Banco de Desastres Naturais do IPMet.

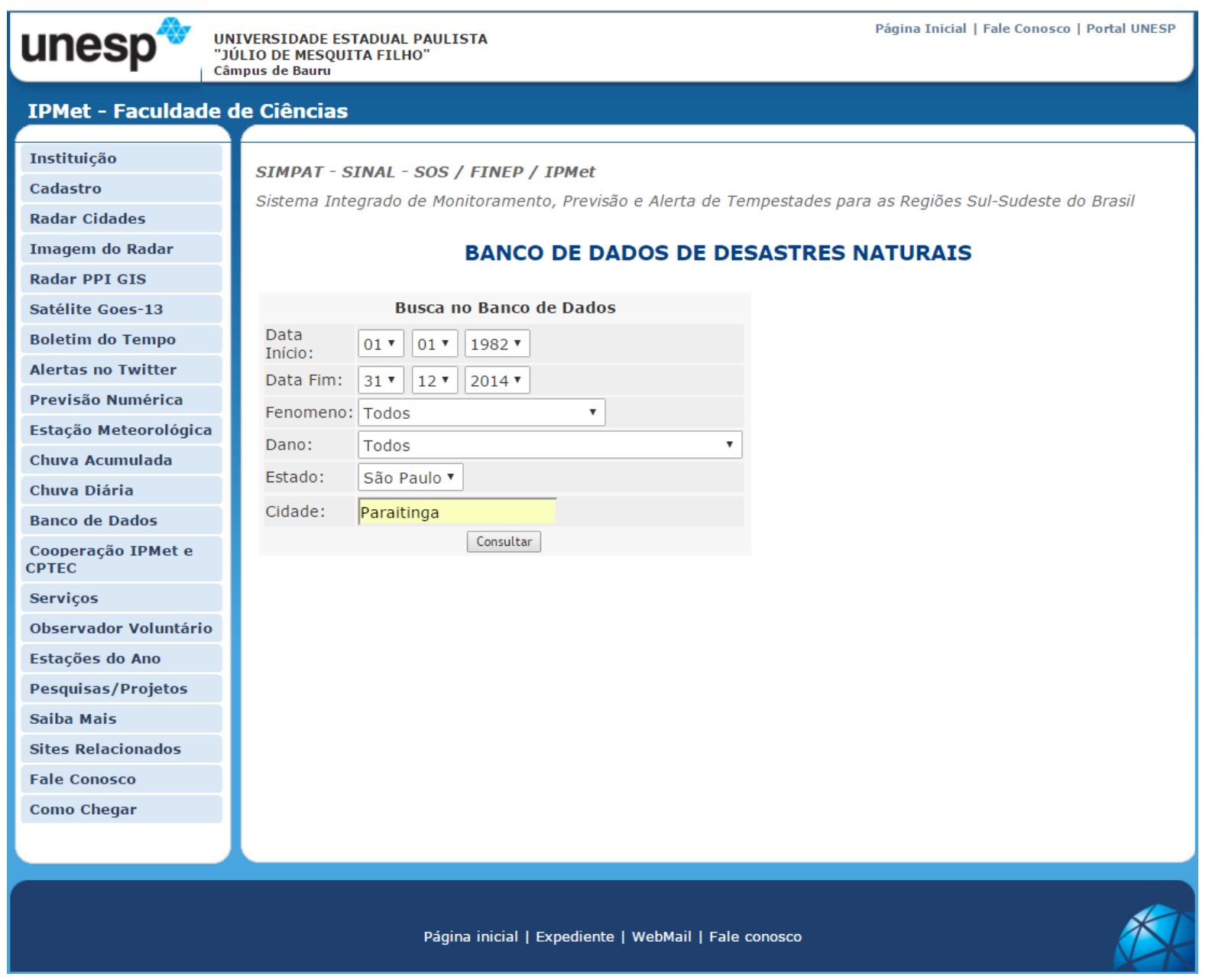

Fonte: Universidade Estadual Paulista "Júlio de Mesquita Filho" (UNESP, 2016). 
Tabela 1. Resultado dos registros obtido da consulta ao Banco de Dados de Desastres Naturais.

\begin{tabular}{|c|c|c|c|c|c|c|c|c|c|c|}
\hline Data & Hora & Fenomeno & Duracao & Endereco & Latitude & Longitude & Ocorrencias & $\begin{array}{l}\text { Total } \\
\text { Danos }\end{array}$ & $\begin{array}{c}\text { Total } \\
\text { Vitimas }\end{array}$ & Fonte \\
\hline 24/02/2004 & -1 & 3 & -1 & -1 & -1 & -1 & $31,32,33$ & -1 & -1 & $\begin{array}{l}\text { Defesa } \\
\text { Civil }\end{array}$ \\
\hline $24 / 01 / 2005$ & -1 & 7 & -1 & -1 & -1 & -1 & $21,26,28$ & -1 & -1 & $\begin{array}{l}\text { Defesa } \\
\text { Civil }\end{array}$ \\
\hline $04 / 04 / 2005$ & tarde & 3 & -1 & -1 & -1 & -1 & 26,33 & -1 & -1 & $\begin{array}{l}\text { Defesa } \\
\text { Civil }\end{array}$ \\
\hline $12 / 02 / 2006$ & $00 \mathrm{~h} 40$ & 7 & -1 & -1 & -1 & -1 & 31,34 & -1 & -1 & $\begin{array}{l}\text { Defesa } \\
\text { Civil }\end{array}$ \\
\hline $22 / 02 / 2006$ & $16 \mathrm{~h} 30$ & 3 & -1 & -1 & -1 & -1 & $20,31,33$ & -1 & -1 & $\begin{array}{l}\text { Defesa } \\
\text { Civil }\end{array}$ \\
\hline 26/12/2006 & $20 \mathrm{~h} 53$ & 3 & 1 hora & -1 & -1 & -1 & 34,43 & -1 & -1 & $\begin{array}{l}\text { Defesa } \\
\text { Civil }\end{array}$ \\
\hline 03/01/2007 & -1 & 7 & 3 dias & -1 & -1 & -1 & 21,33 & -1 & -1 & $\begin{array}{l}\text { Defesa } \\
\text { Civil }\end{array}$ \\
\hline 03/01/2008 & $\begin{array}{c}\text { madrug } \\
\text { ada }\end{array}$ & 3 & -1 & -1 & -1 & -1 & $\begin{array}{c}21,26,28,30 \\
33\end{array}$ & -1 & -1 & $\begin{array}{l}\text { Defesa } \\
\text { Civil }\end{array}$ \\
\hline 21/12/2008 & $17 \mathrm{~h}$ & 2,3 & -1 & -1 & -1 & -1 & $26,28,33$ & -1 & -1 & $\begin{array}{l}\text { Defesa } \\
\text { Civil }\end{array}$ \\
\hline $15 / 02 / 2009$ & $01 \mathrm{~h} 20$ & 3 & longa duração & -1 & -1 & -1 & $\begin{array}{c}20(62), 21(10 \\
), 31,33(25)\end{array}$ & 97 & 72 & $\begin{array}{l}\text { Defesa } \\
\text { Civil }\end{array}$ \\
\hline 21/10/2009 & $02 \mathrm{~h} 00$ & 7,8 & & & -1 & -1 & 21,28 e 34 & -1 & -1 & $\begin{array}{l}\text { Defesa } \\
\text { Civil }\end{array}$ \\
\hline 08/12/2009 & -1 & 3,8 & -1 & -1 & -1 & -1 & $\begin{array}{c}21,25,26,31( \\
17), 33,34\end{array}$ & 17 & -1 & $\begin{array}{l}\text { Defesa } \\
\text { Civil }\end{array}$ \\
\hline
\end{tabular}




\begin{tabular}{|c|c|c|c|c|c|c|c|c|c|c|}
\hline Data & Hora & Fenomeno & Duracao & Endereco & Latitude & Longitude & Ocorrencias & $\begin{array}{l}\text { Total } \\
\text { Danos }\end{array}$ & $\begin{array}{c}\text { Total } \\
\text { Vitimas }\end{array}$ & Fonte \\
\hline $09 / 12 / 2009$ & -1 & 7,8 & -1 & -1 & -1 & -1 & $21,26,28,33$ & -1 & -1 & $\begin{array}{c}\text { Defesa } \\
\text { Civil }\end{array}$ \\
\hline $10 / 12 / 2009$ & $17 \mathrm{~h} 15$ & 7,8 & -1 & -1 & -1 & -1 & $\begin{array}{c}21,26,28,31 \\
32,34,43\end{array}$ & -1 & -1 & $\begin{array}{c}\text { Defesa } \\
\text { Civil }\end{array}$ \\
\hline $31 / 12 / 2009$ & $\begin{array}{c}\text { noite e } \\
\text { dia }\end{array}$ & $3,7,8$ & Dias & -1 & -1 & -1 & $\begin{array}{c}4000(20), \\
5000(21), \\
2(22), 1(23), \\
24,26,27, \\
12(31), \\
844(33), 37, \\
43 \text { e } 48\end{array}$ & 9859 & 9003 & $\begin{array}{c}\text { Defesa } \\
\text { Civil }\end{array}$ \\
\hline 03/01/2010 & manhã & 3 & -1 & -1 & -1 & -1 & $\begin{array}{l}1(23), 26 \\
27,31 \text { e } 46\end{array}$ & 1 & 1 & G1 \\
\hline $19 / 12 / 2010$ & $14 \mathrm{~h} 30$ & 3,8 & 01 hora & -1 & -1 & -1 & $26,33(20)$ & 20 & -1 & $\begin{array}{c}\text { Defesa } \\
\text { Civil }\end{array}$ \\
\hline 08/01/2011 & $18 \mathrm{~h} 00$ & 3 & $\begin{array}{l}40 \text { minutos } \\
(43 \mathrm{~mm})\end{array}$ & -1 & -1 & -1 & $\begin{array}{c}24(3), 30,33( \\
43)\end{array}$ & 46 & -1 & $\begin{array}{c}\text { Defesa } \\
\text { Civil }\end{array}$ \\
\hline $22 / 11 / 2011$ & -1 & 2,3 & $53 \mathrm{~km} / \mathrm{h}$ & -1 & -1 & -1 & 25 & -1 & -1 & CPTEC \\
\hline $11 / 01 / 2013$ & $18: 00 \mathrm{~h}$ & 8 & longa duração & -1 & -1 & -1 & $21(26), 26,8$ & 26 & 26 & $\begin{array}{c}\text { Defesa } \\
\text { Civil }\end{array}$ \\
\hline
\end{tabular}

Fonte: Banco de Dados de Desastres Naturais - IPMet. Organizado pela autora (2016). 
Tabela2-Legenda de Danos e Descrição do Fenômeno. Banco de Dados de Desastres Naturais. IPMet.

\begin{tabular}{|c|c|c|c|}
\hline $\begin{array}{c}\text { Código_Ocorrencias__ } \\
\text { Dano }\end{array}$ & $\begin{array}{c}\text { Descricao_Ocorrencias__ } \\
\text { Dano } \\
\end{array}$ & $\begin{array}{c}\text { Codigo } \\
\text { fenomeno }\end{array}$ & Descricao_fenomeno \\
\hline-1 & Sem informação & 1 & Granizo \\
\hline 20 & Desabrigado(s) & 2 & Ventos fortes/vendaval \\
\hline 21 & Desalojado(s) & 3 & Chuvas fortes \\
\hline 22 & Ferido(s) & 4 & Raio \\
\hline 23 & Vítima(s) fatal(is) & 5 & Tornado \\
\hline 24 & Queda de Barreira & 6 & Ciclone \\
\hline 25 & Queda de Árvores & 7 & Frente fria/chuvas contínuas \\
\hline 26 & $\begin{array}{l}\text { Transbordamento de Rios } \\
\text { e Córregos }\end{array}$ & 8 & Chuvas moderadas \\
\hline 27 & Danos em Pontes & 9 & Geadas \\
\hline 28 & Inundações Graduais & 10 & Estiagem \\
\hline 29 & Enchentes & & \\
\hline 30 & Alagamentos & & \\
\hline 31 & Deslizamento de terra & & \\
\hline 32 & Queda de Muro & & \\
\hline 33 & $\begin{array}{c}\text { Desabamentos/Rachadura/ } \\
\text { Danos em Imóveis }\end{array}$ & & \\
\hline 34 & $\begin{array}{l}\text { Congestionamento/Interdiç } \\
\text { ão de Via Pública }\end{array}$ & & \\
\hline 35 & Danos em Veículos & & \\
\hline 36 & Destelhamentos & & \\
\hline 37 & $\begin{array}{c}\text { Corte no fornecimento de } \\
\text { energia e água }\end{array}$ & & \\
\hline 38 & $\begin{array}{c}\text { Destruição de Plantação e } \\
\text { Estrada Rural }\end{array}$ & & \\
\hline 39 & Erosão/Buraco & & \\
\hline 40 & Queda de Poste & & \\
\hline 41 & $\begin{array}{c}\text { Desbarrancamento da } \\
\text { Margem do Rio } \\
\text { Acidente com }\end{array}$ & & \\
\hline 42 & $\begin{array}{c}\text { Aeronave/Aeroporto } \\
\text { Fechado }\end{array}$ & & \\
\hline 43 & $\begin{array}{l}\text { Escorregamento de } \\
\text { Encosta }\end{array}$ & & \\
\hline 44 & Acidente com carro & & \\
\hline 45 & $\begin{array}{c}\text { Pessoa arrastada pela } \\
\text { enxurrada }\end{array}$ & & \\
\hline 46 & $\begin{array}{c}\text { Danificação em } \\
\text { Pavimentação }\end{array}$ & & \\
\hline 47 & Rompimento de Barragem & & \\
\hline 48 & $\begin{array}{l}\text { Rompimento da Rede de } \\
\text { Água e Esgoto }\end{array}$ & & \\
\hline 49 & Acidente com Trem & & \\
\hline
\end{tabular}




\begin{tabular}{|c|c|c|c|}
\hline $\begin{array}{c}\text { Código_Ocorrencias_ } \\
\text { Dano }\end{array}$ & $\begin{array}{c}\text { Descricao_Ocorrencias_ } \\
\text { Dano }\end{array}$ & $\begin{array}{c}\text { Codigo } \\
\text { fenomeno }\end{array}$ & Descricao_fenomeno \\
\hline 50 & $\begin{array}{l}\text { Afogamento dentro da } \\
\text { residência }\end{array}$ & & \\
\hline 51 & Danos causados por raio & & \\
\hline 52 & Queda de Torre & & \\
\hline 53 & Queda de Outdoor & & \\
\hline 54 & Inundações Litorâneas & & \\
\hline 55 & Animais mortos por raio & & \\
\hline 56 & Enxurradas & & \\
\hline 57 & Inundações Bruscas & & \\
\hline 58 & Acidente com Embarcação & & \\
\hline
\end{tabular}

Fonte: Organizado pela autora (2016).

\subsection{Coleta e processamento dos dados de precipitação}

A consulta dos dados de precipitação foi realizada a partir do Hidroweb, plataforma online da Agência Nacional de Águas (ANA) na qual disponibiliza ao usuário dados de uma rede de estações hidrometeorológicas alocadas por todo o Brasil. Para ter acesso aos dados de chuva o usuário deve entrar no site do Hidroweb, selecionar "Dados Hidrológicos" e depois "Séries Históricas"; e então baixar o documento ou em arquivo formato Access ou arquivo formato texto. Para a pesquisa optou-se por baixar os dados em formato texto e abri-los em planilhas Excel para sua análise.

Figura 4 - Layout antigo da plataforma Hidroweb.

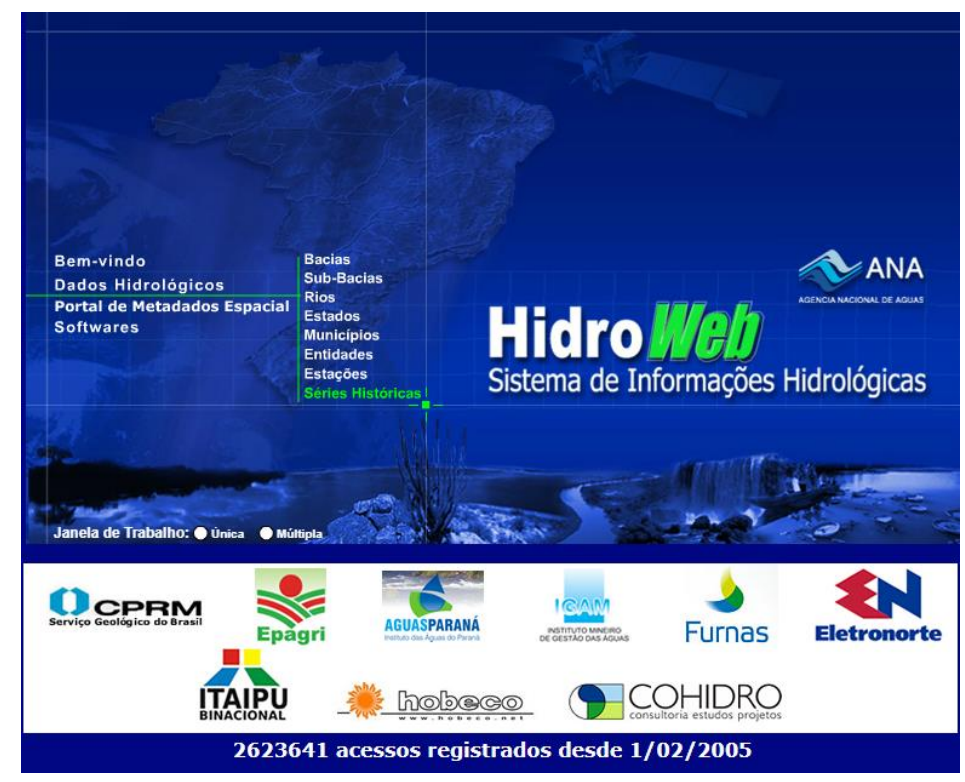

Fonte: Agência Nacional de Águas (2016). 


\subsubsection{Escolha das estações}

De acordo com o livro de Inventário das Estações Pluviométricas da ANA, existem em São Luiz do Paraitinga 12 estações pluviométricas. No entanto nem todas possuem registros suficientes dentro do período determinado para o estudo (32 verões). Dessa forma, foi necessário fazer um pré-processamento dos dados e seleção das estações de forma que fossem utilizadas aquelas que estivessem dentro do limite municipal de São Luiz do Paraitinga e que tivessem dados de precipitação disponíveis para o período de 1982 a 2014. As estações e a disponibilidade de dados são apresentadas na tabela a seguir:

Tabela 3. Estações pluviométricas de São Luíz do Paraitinga - SP.

\begin{tabular}{|c|c|c|c|c|c|}
\hline Código da Estação & Início da coleta & Fim da coleta & Órgão Responsável & $\begin{array}{l}\text { Presença de } \\
\text { falhas }\end{array}$ & Útil \\
\hline 2345065 & $01 / 08 / 1930$ & não consta & ANA & Não & Sim \\
\hline 2345017 & 01/04/1971 & não consta & FCTH/DAEE-SP & Sim & Sim \\
\hline 2345067 & 01/08/1933 & não consta & ANA & Não & Sim \\
\hline 2345175 & 01/10/1972 & não consta & FCTH/DAEE-SP & Sim & Sim \\
\hline 2345021 & $01 / 11 / 1947$ & não consta & FCTH/DAEE-SP & Sim & Não \\
\hline 2345171 & 01/05/1956 & não consta & FCTH/DAEE-SP & Sim & Não \\
\hline 2345118 & $01 / 03 / 1953$ & 01/08/1993 & LIGHT & Sim & Não \\
\hline 2345149 & 01/01/1940 & 01/07/1969 & FCTH/DAEE-SP & $\begin{array}{l}\text { Fora do } \\
\text { período }\end{array}$ & Não \\
\hline 2345104 & $01 / 03 / 1953$ & 01/08/1993 & LIGHT & Sim & Não \\
\hline 2345069 & $01 / 02 / 1935$ & 01/11/1978 & ANA & $\begin{array}{l}\text { Fora do } \\
\text { período }\end{array}$ & Não \\
\hline 2345061 & 01/01/1940 & 01/07/1969 & FCTH/DAEE-SP & $\begin{array}{l}\text { Fora do } \\
\text { período }\end{array}$ & Não \\
\hline 2345021 & 01/11/1947 & não consta & FCTH/DAEE-SP & Sim & Não \\
\hline
\end{tabular}

Fonte: Agência Nacional de Águas, Brasil (ANA, 2009).

As estações que apresentam menos de $50 \%$ dos dados necessários para a pesquisa foram desconsideradas, são elas: 2345021, 2345171, 2345118, 2345149, 2345104, 2345069, 2345061, 2345021. As outras, 2345017 e 2345175, por apresentarem falhas em menores proporções, foram utilizadas. As estações 2345065 e 2345067 não apresentaram falhas no período pretendido, por isso foram utilizadas também. 
A questão de falhas em séries históricas de dados climatológicos é bem comum e desafiadora para o(a) pesquisador(a). Ao mesmo tempo em que, quanto mais dados melhor para a representação da realidade, na prática não há um sério comprometimento para a manutenção das estações coletoras.

Em casos de séries históricas com dados faltantes, é preciso recorrer às técnicas de preenchimento de falhas. É importante lembrar que os dados preenchidos não podem ser a maioria dentro da série utilizada, isso porque, o preenchimento de falhas nunca será igual ao dado original.

No que diz respeito a estudos sobre extremos climáticos as técnicas de preenchimento de falhas são ainda menos recomendadas (MELLO,; KOHLS, OLIVEIRA, 2017). Isso porque o objeto de estudo são os dados em outlier e não aqueles que seguem determinado padrão.

Na presente pesquisa, optou-se por utilizar os dados das estações mais próximas entre si para preencher os dados faltantes. Isso porque, após realizado o diagrama de dispersão (Figuras de 5 a 8) verificou-se que os valores entre tais estações são bem próximos.

Uma vez que o diagrama de dispersão explica o comportamento de duas variáveis resultado de um mesmo processo e que o coeficiente de determinação $\left(\mathrm{r}^{2}\right)$ aplicado nas estações em estudo resultou em valores acima de 0,88, optou-se por utilizar tal estratégia para o preenchimento dos dados faltantes.

Dessa forma, os dados das estações 02345065 e 02345017 se completaram enquanto que as estações 02345175 e 02345067 completaram entre si em decorrência de sua proximidade geográfica e coeficiente de determinação $\mathrm{r}^{2}$ alto (acima ou igual a 0,88 ). 
Figura 5. Diagrama de dispersão entre 02345175 e 02345067 entre os anos 1998 e 1999.

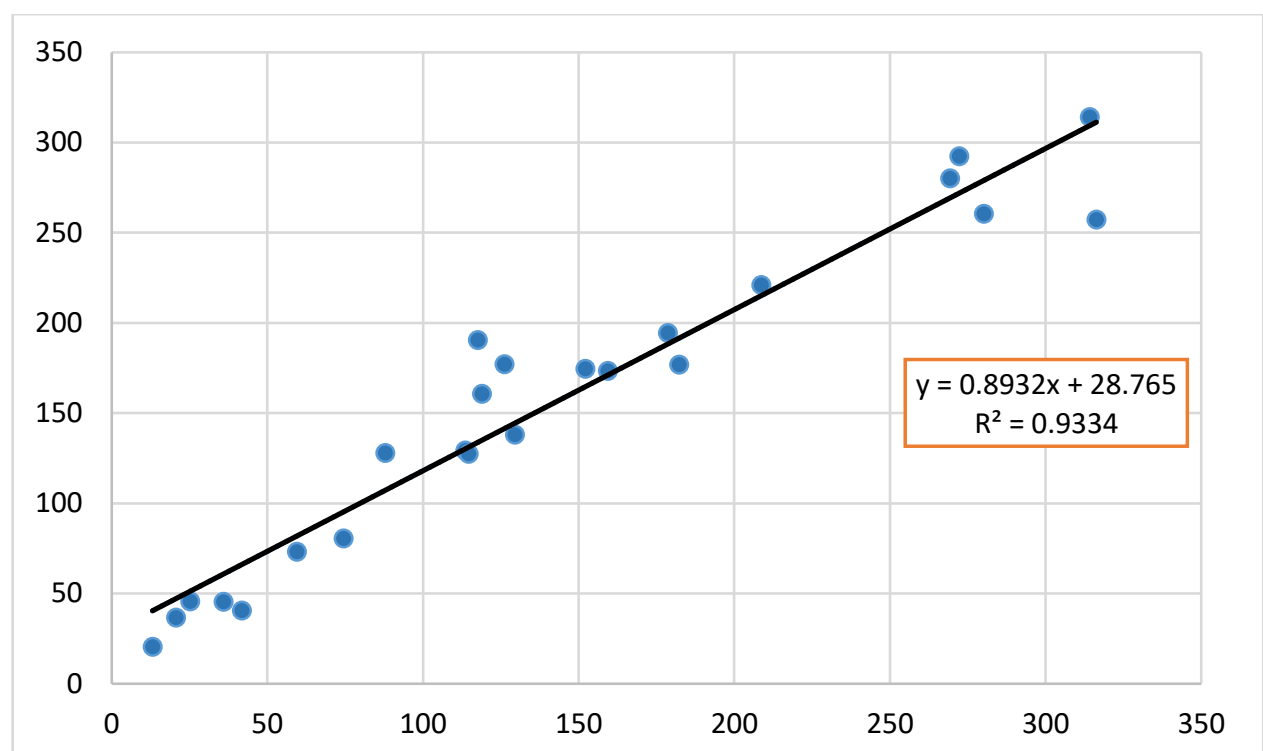

Fonte: Agência Nacional de Águas (2016). Organizado pela autora (2016)

Figura 6. Diagrama de dispersão entre 02345175 e 02345067 entre os anos 2013 e 2014.

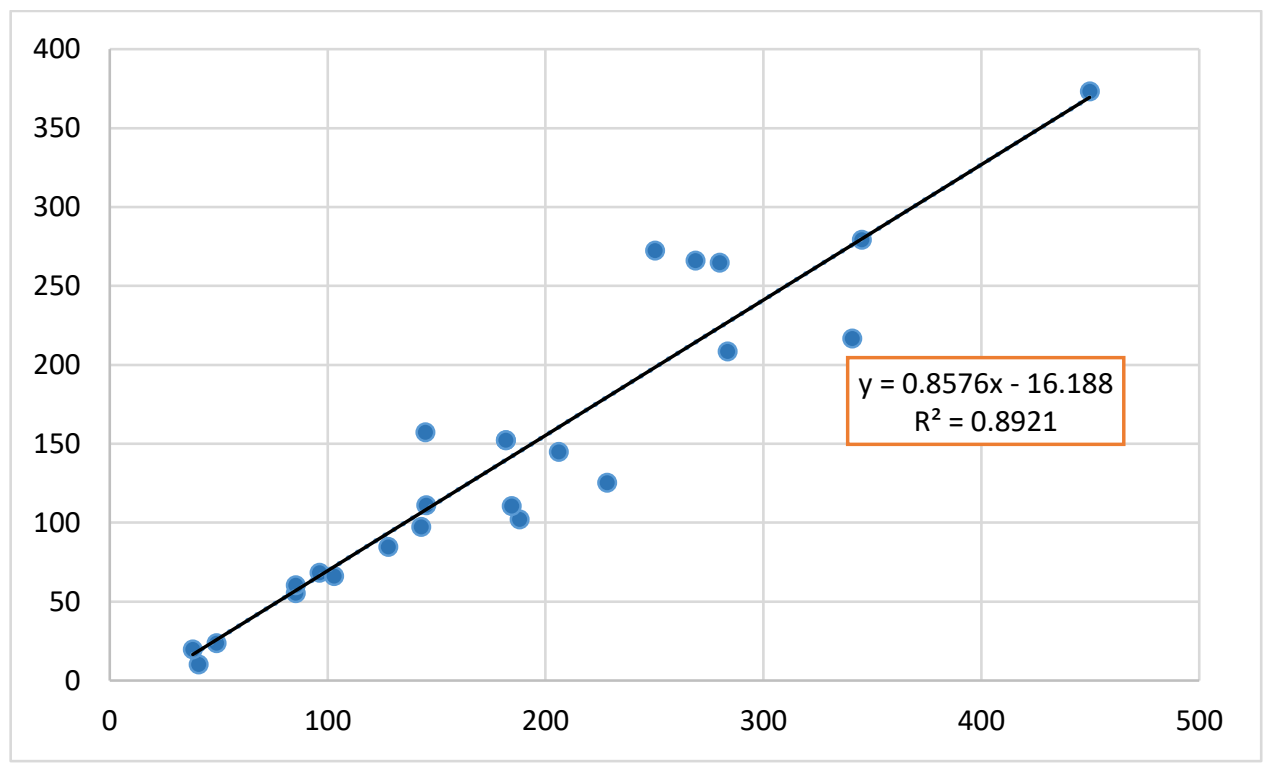

Fonte: Agência Nacional de Águas (2016). Organizado pela autora (2016) 
Figura 7. Diagrama de dispersão entre 02345017 e 02345065 entre os anos de 2010 - 2011.

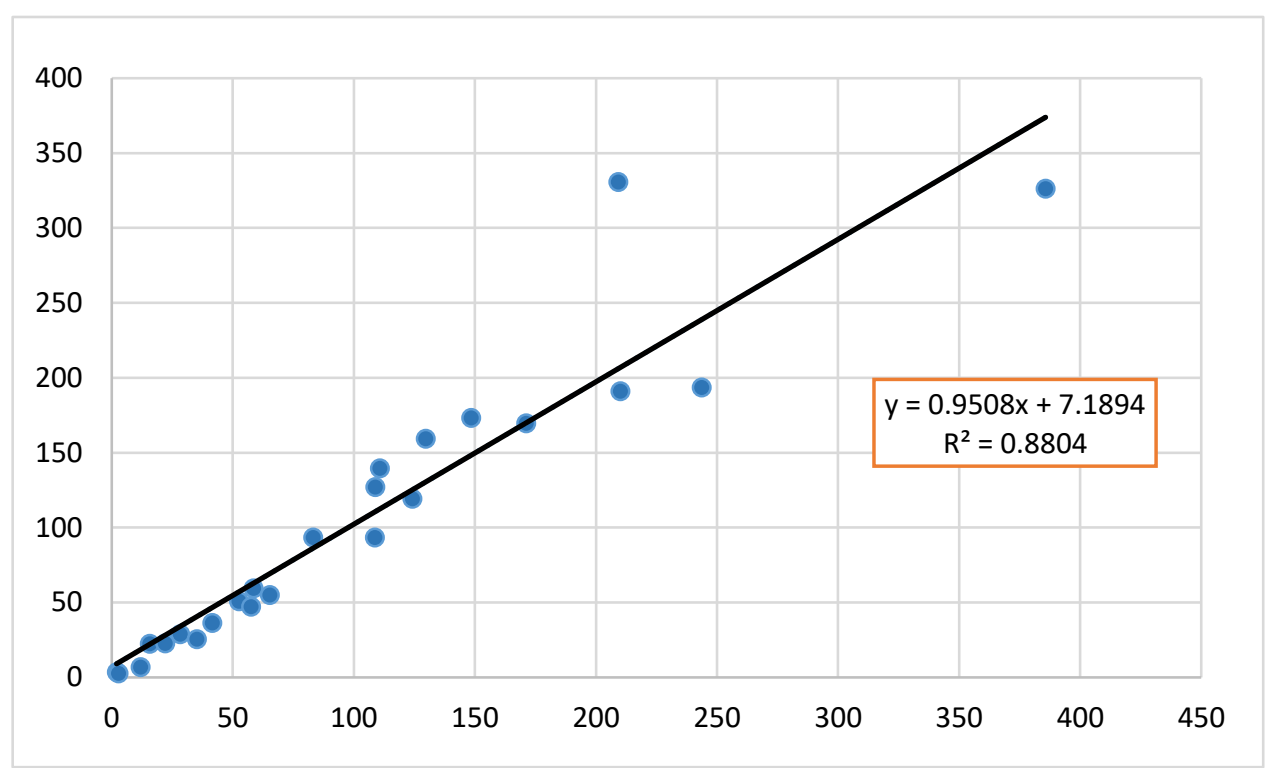

Fonte: Agência Nacional de Águas (2016). Organizado pela autora (2016).

Figura 8. Diagrama de dispersão entre 02345017 e 02345065 entre 1998 - 1999.

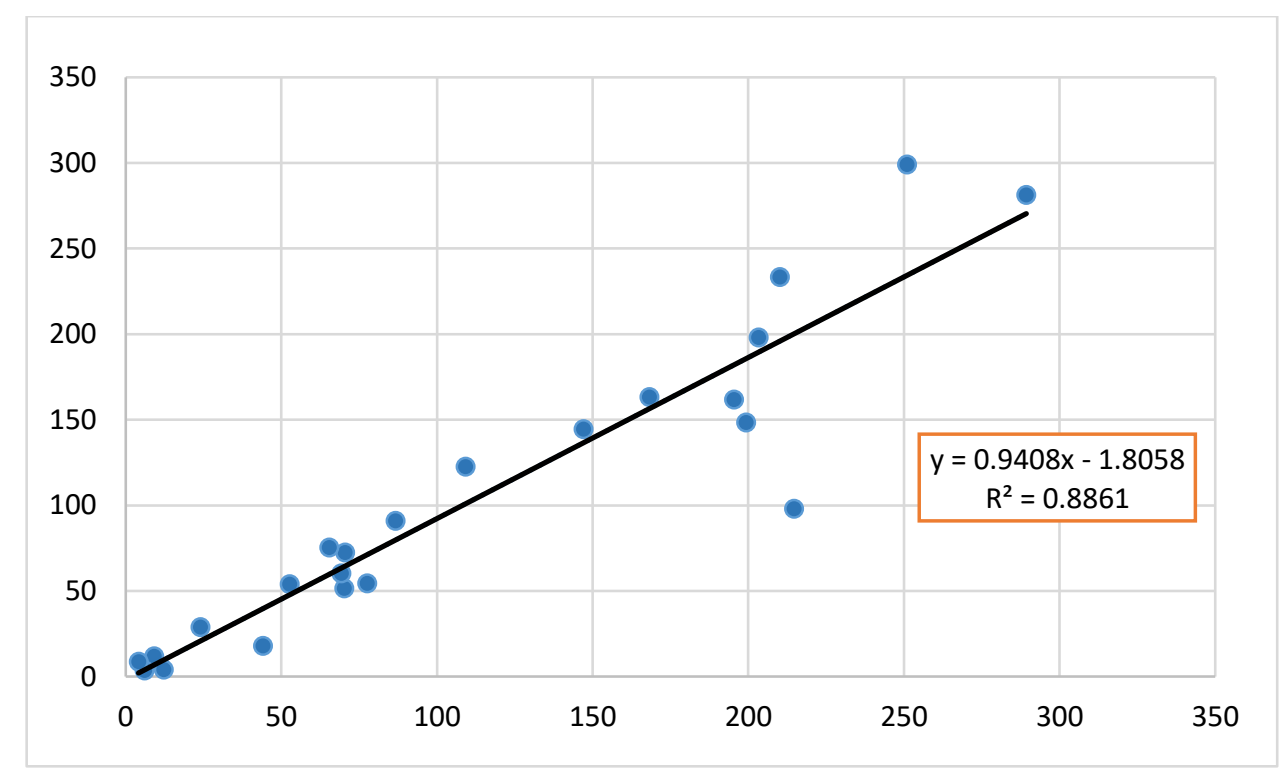

Fonte: Agência Nacional de Águas (2016). Organizado pela autora (2016).

As estações utilizadas 02345017, 02345065,02345175 e 02345067 estão representadas no mapa seguinte: 
Figura 9. Localização das estações pluviais escolhidas no município de São Luiz do Paraitinga - SP.

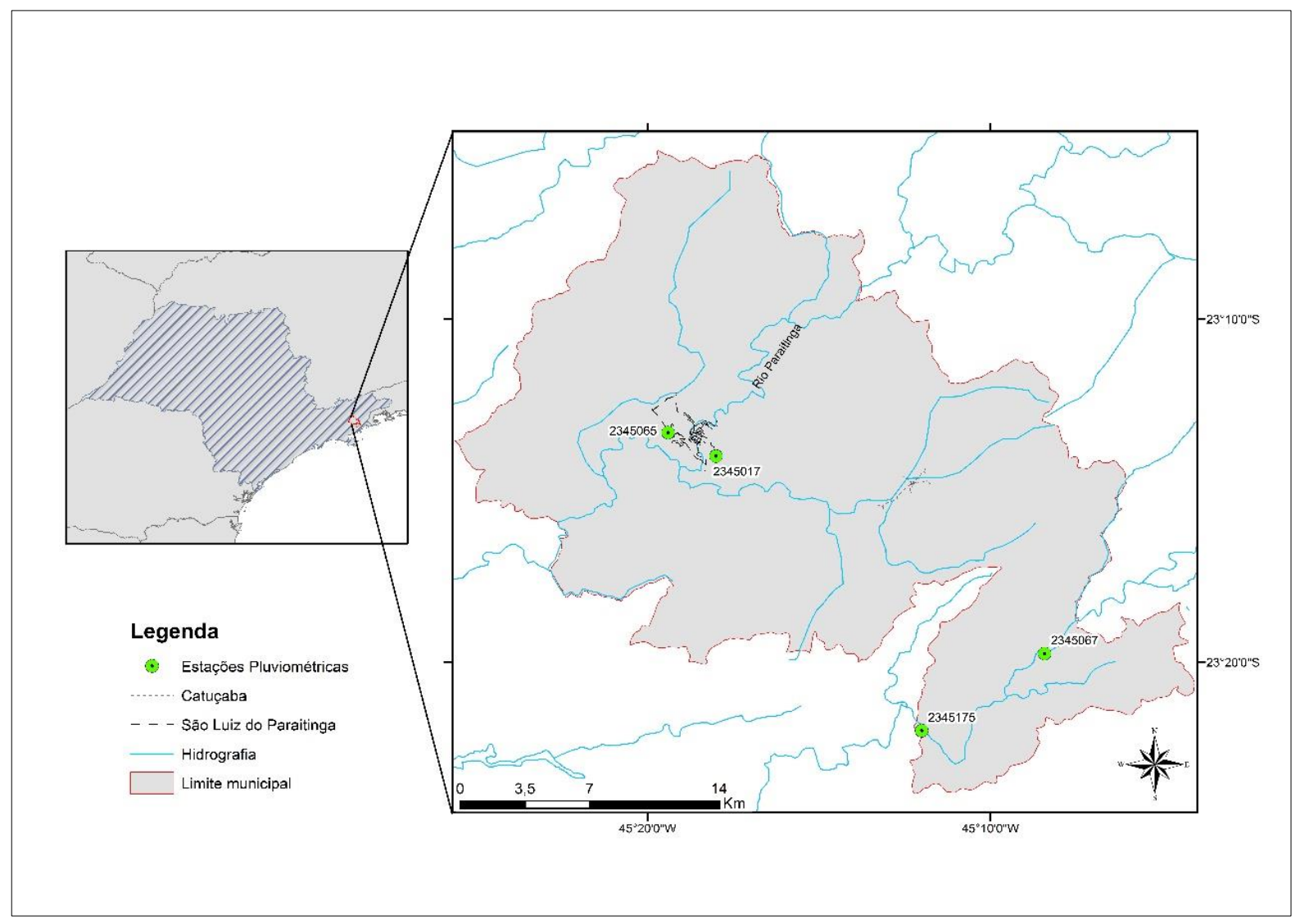

Fonte: Organizado pela autora (2016).

No mapa acima encontra-se a delimitação no município de São Luiz do Paraitinga tanto em sua área rural como urbana. A linha cinza tracejada a noroeste do município refere-se à malha urbana da cidade, na qual estão próximas as estações 02345065 e as estações 02345017 . Essas mesmas estações estão representadas também no Figura 10, onde é possível ver detalhadamente o uso do solo na cidade, de acordo com o Plano Diretor de 2010.

As estações 02345017 e 02345067 encontram-se a sudeste do município, mais afastadas da cidade e mais próximas da Serra do Mar. Não é possível localizá-las na Figura 10 em decorrência da abrangência da imagem. 
Figura 10. Mapa de localização das estações próximas à área urbana de São Luiz do Paraitinga - SP.

Localização das estações próximas à cidade de São Luiz do Paraitinga - SP e o uso e ocupação do solo na cidade.

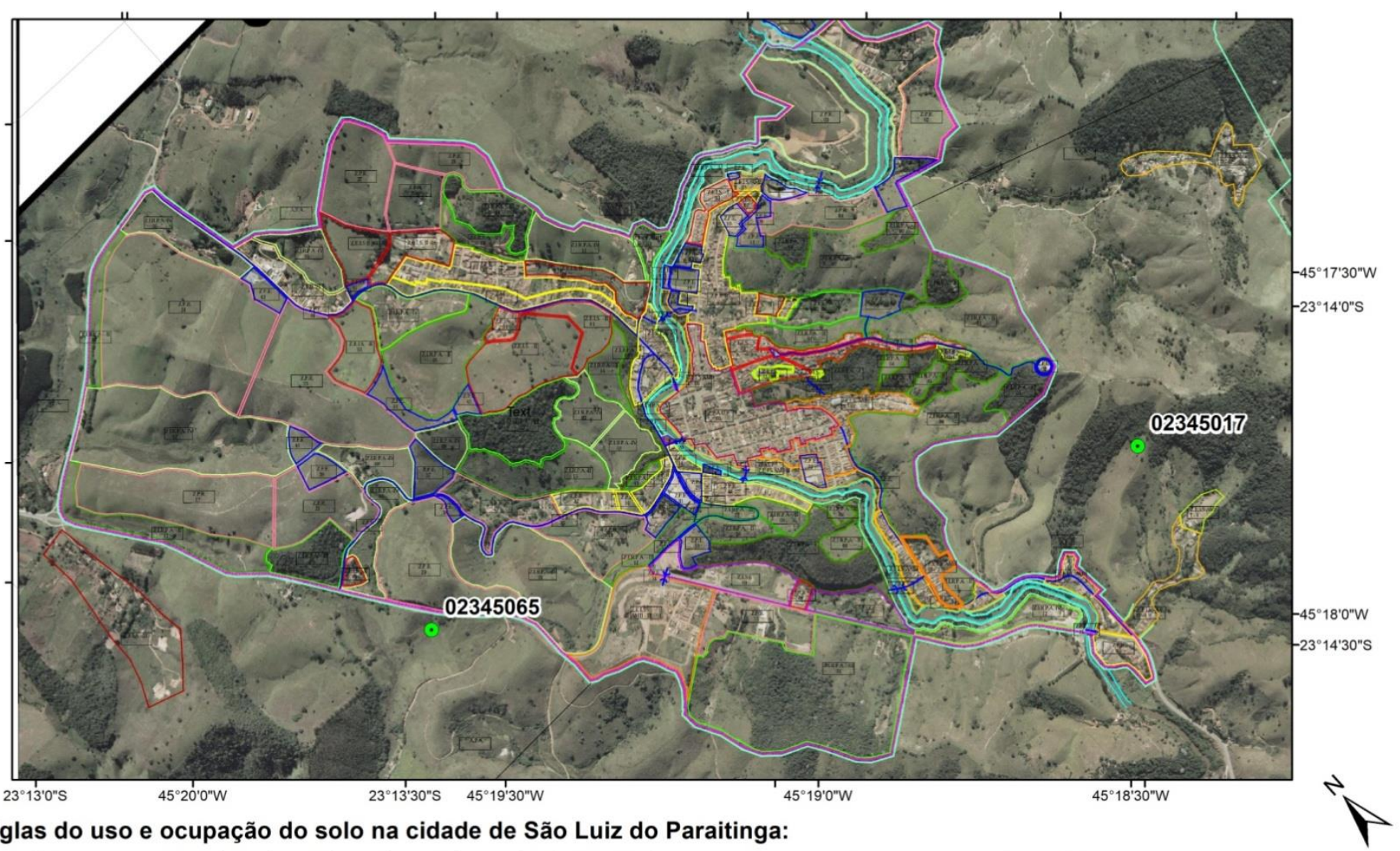

Zona de Preservação Arquitetônica, Urbanística e Paisagística (Z.P.A.U.P.) Z Zonas Mista com incentivo à moradia (Z.M.)

Zona Preferencialmente Residencial (Z.P.R.)

Zona Industrial, de Serviços e Comércio (Z.I.S.C.)

Zona Especial de Interesse Social (Z.E.I.S.)

Zona de Incentivo a Recuperação e Preservação Ambiental (Z.I.R.P.A.) Distrito Agroindustrial.

Zonas de Projetos Especiais (Z.P.E.)

Zona Especial de Interesse Social e Ambiental (Z.E.IS. AMB.) 


\subsubsection{Escolha da escala espaço-temporal}

Um dos objetivos da pesquisa foi o de compreender a variabilidade da chuva em São Luiz do Paraitinga em seu aspecto sazonal e quantitativo para poder conhecer aqueles valores de precipitação considerados dentro da normalidade climática e aqueles considerados extremos. A Organização Meteorológica Mundial (OMM) estabelece como convenção para estudos sobre o clima uma série de dados com no mínimo 30 anos de duração. Por isso, foram compilados os dados de precipitação referentes a uma série histórica de 32 verões, desde o verão de 1982/1983 até o verão de 2013/2014. Esse ínterim foi escolhido em decorrência da disponibilidade simultânea dos dados de precipitação e das ocorrências de impactos no Banco de Dados de Desastres Naturais.

O gráfico abaixo produzido pelo CPTEC/INPE evidencia a diferença de valor precipitado entre os meses de Janeiro a Dezembro na Região 114 referente à área onde São Luiz do Paraitinga encontra-se. É possível perceber um acréscimo brusco de quantidade precipitada na passagem de novembro para dezembro e um decréscimo brusco de quantidade precipitada na passagem de março para abril.

A coletânea de imagens organizadas na figura 11 mostra a distribuição da precipitação de cada ano dos eventos ocorridos em comparação com a série de 1981 a 2010. Essa sequência de gráficos evidencia que as chuvas acima da média anual ocorrem nos meses de dezembro a março. Dentre esses meses dezembro e janeiro apresentam outliers e, nos meses de dezembro, janeiro e fevereiro, a mediana dos valores de precipitação está mais próximo dos valores acima da média.

Figura 11. Boxplots de precipitação mensal de 1981 - 2010 da Região 114.
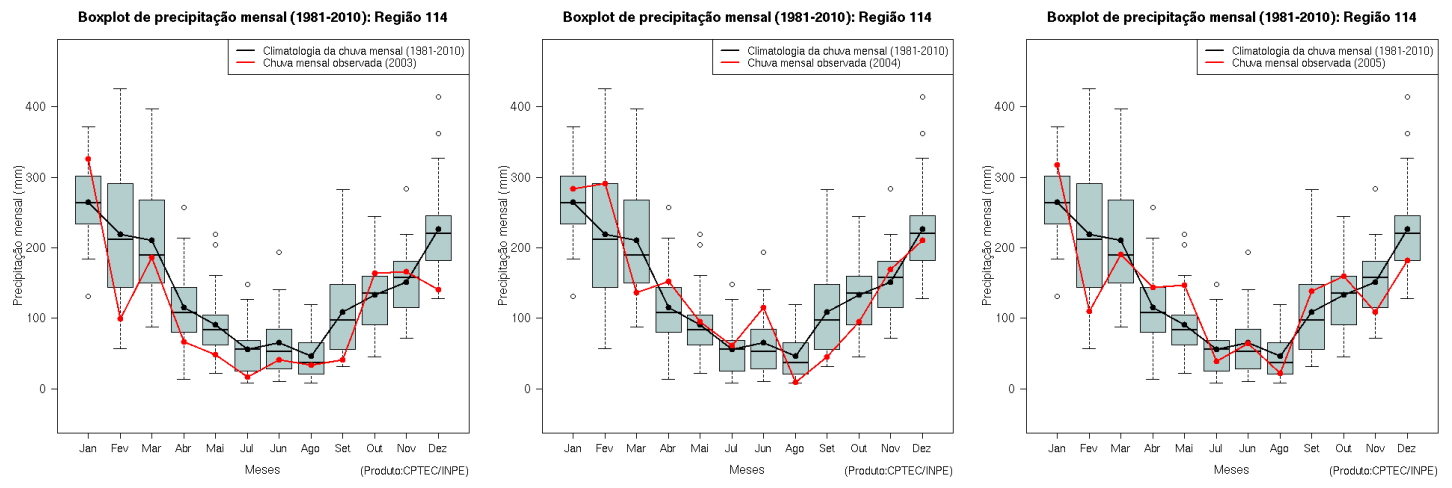

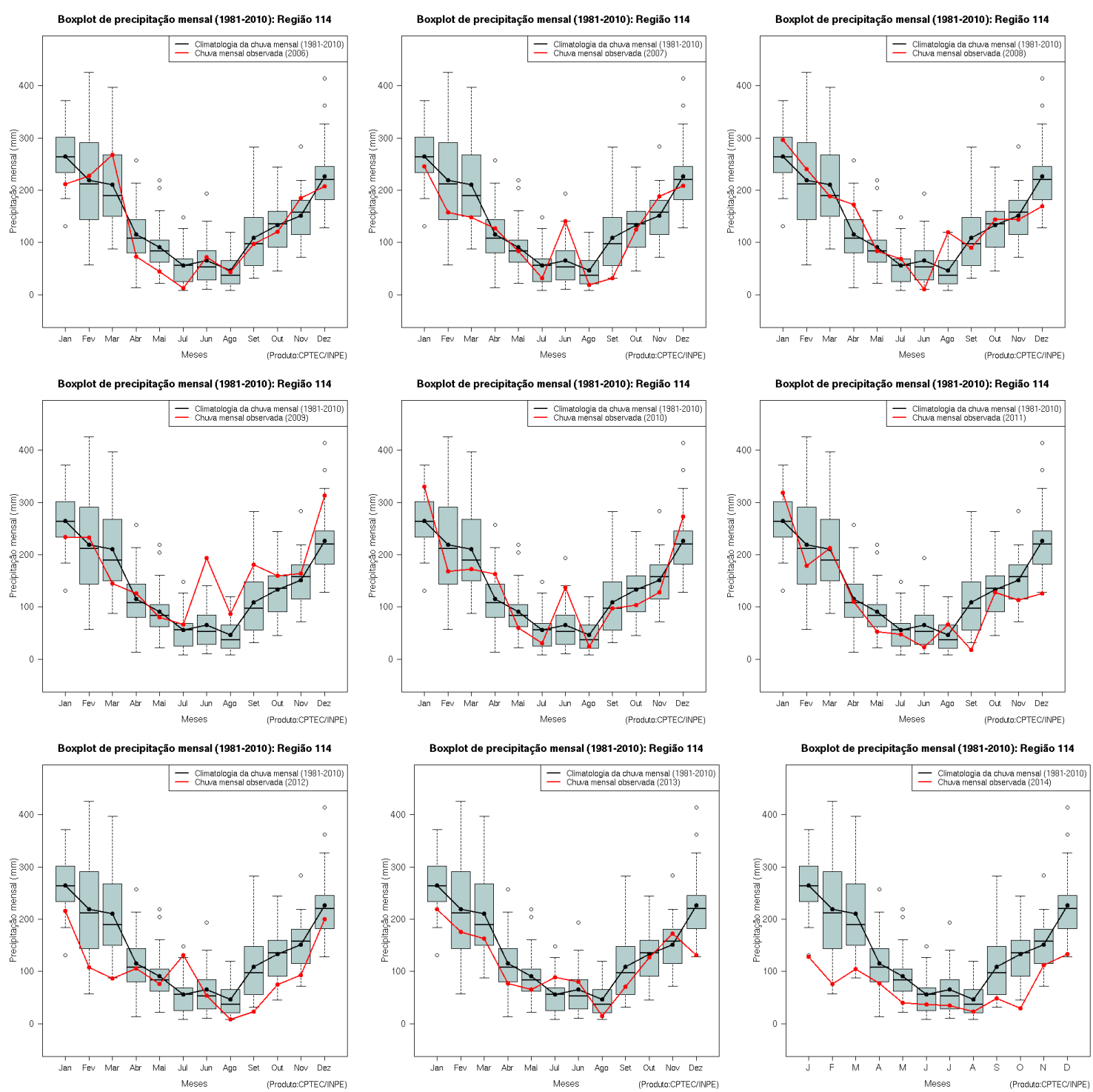

Fonte: Instituto Nacional de Pesquisas Espaciais - INPE (2017).

Não de forma isolada a isso é o fato de que a maioria dos registros de impactos provocados pelas chuvas em São Luiz do Paraitinga é ocorrida durante os verões (PELLEGRINA, 2011). Dessa forma optou-se por selecionar e agrupar os dados de precipitação referente aos meses de Dezembro, Janeiro e Fevereiro. E então poder trabalhar com as medidas estatísticas que serão explicadas no item a seguir.

\subsubsection{Mensuração das medidas estatísticas dentro da série de 32 verões}

As medidas de estatística descritiva utilizadas tiveram como base a obra de Boin e Zavattini (2013). Segundo os autores, a estatística descritiva aplicada a estudos de precipitação ajuda a 
compreender a variação do regime de chuva durante uma série histórica. Tais medidas escolhidas para o presente estudo foram: total acumulado, desvio da média e histograma.

Sabendo que o regime de chuvas de São Luiz do Paraitinga apresenta no período de verão, acumulados com maior precipitação entre os meses de dezembro, janeiro e fevereiro, optou-se por utilizar esses três meses como uma escala sazonal-temporal dentro de uma série de 32 anos (1982 a 2014), em decorrência da disponibilidade dos dados.

O Total Acumulado expressa, em milímetros, a somatória de chuvas durante o verão na seguinte fórmula:

$$
\sum \mathrm{dez}, \mathrm{jan}, \mathrm{fev}
$$

Porém, o total acumulado por si só não apresenta o valor comparado aos outros verões da série, para se ter tal comparação aplicou-se o desvio da média, na qual calculou-se a média dos 32 verões e subtraiu-se o total acumulado de cada verão à média da série, segundo a fórmula:

$$
\mathrm{y}=\sum \mathrm{dez}, \mathrm{jan}, \mathrm{fev}-\overline{\mathrm{x}} \quad \begin{aligned}
& \mathrm{y}=\text { Desvio da média } \\
& \bar{x}=\text { média da série }
\end{aligned}
$$

O histograma, por sua vez, permite verificar quantas vezes uma classe de valores aparece na série. Para a produção do histograma foi utilizado a fórmula de Sturges, definida pela fórmula abaixo e posteriormente traduzida para o script em python:

$$
\begin{gathered}
\mathrm{k}=1+\left(3,3 \log _{\mathrm{n}}\right) \\
\therefore \mathrm{k}=1+\left(3,3 \log _{32}\right) \\
\therefore \mathrm{k}=6
\end{gathered}
$$

Feito a seleção das medidas estatísticas para a análise climática foi necessário organizar os dados e aplicar os índices. O algoritmo e o fluxograma da Figura 12 a seguir descrevem tal etapa: 


\subsubsection{Algoritmo da análise estatística}

1) Download da estação convencional no Hidroweb;

2) Organização num banco de dados particular em excel;

2.1) Organização por verão (DEZ-JAN-FEV)

3) Importação para o Canopy;

4) Ínício da escrita do código em python:

4.1.1) Ordenar coluna de datas - para verificar se há dados de 1982 a 2014;

4.1.2) A série precisa ser completada?

Sim $\rightarrow$ Verifique por $r^{2}$ se há uma estação que possa completá-la.

Não $\rightarrow$ Nãoa use.

4.1.3) Complementação das falhas;

A série pode ser completada?

$\mathrm{Sim} \rightarrow$ Complete a série pelo método $\mathrm{r}^{2}$.

Não $\rightarrow$ Não a use.

4.1) Aplicação das medidas estatísticas dentro da série;

3.2.1) Total acumulado de precipitação de cada verão;

3.2.2) Média dos verões da série;

3.2.3) Desvio da média para cada verão;

3.2.4) Histograma (pela fórmula de Sturges).

4.2) Organização dos gráficos e resultados;

5) Análise dos dados. 
Figura 12. Fluxograma

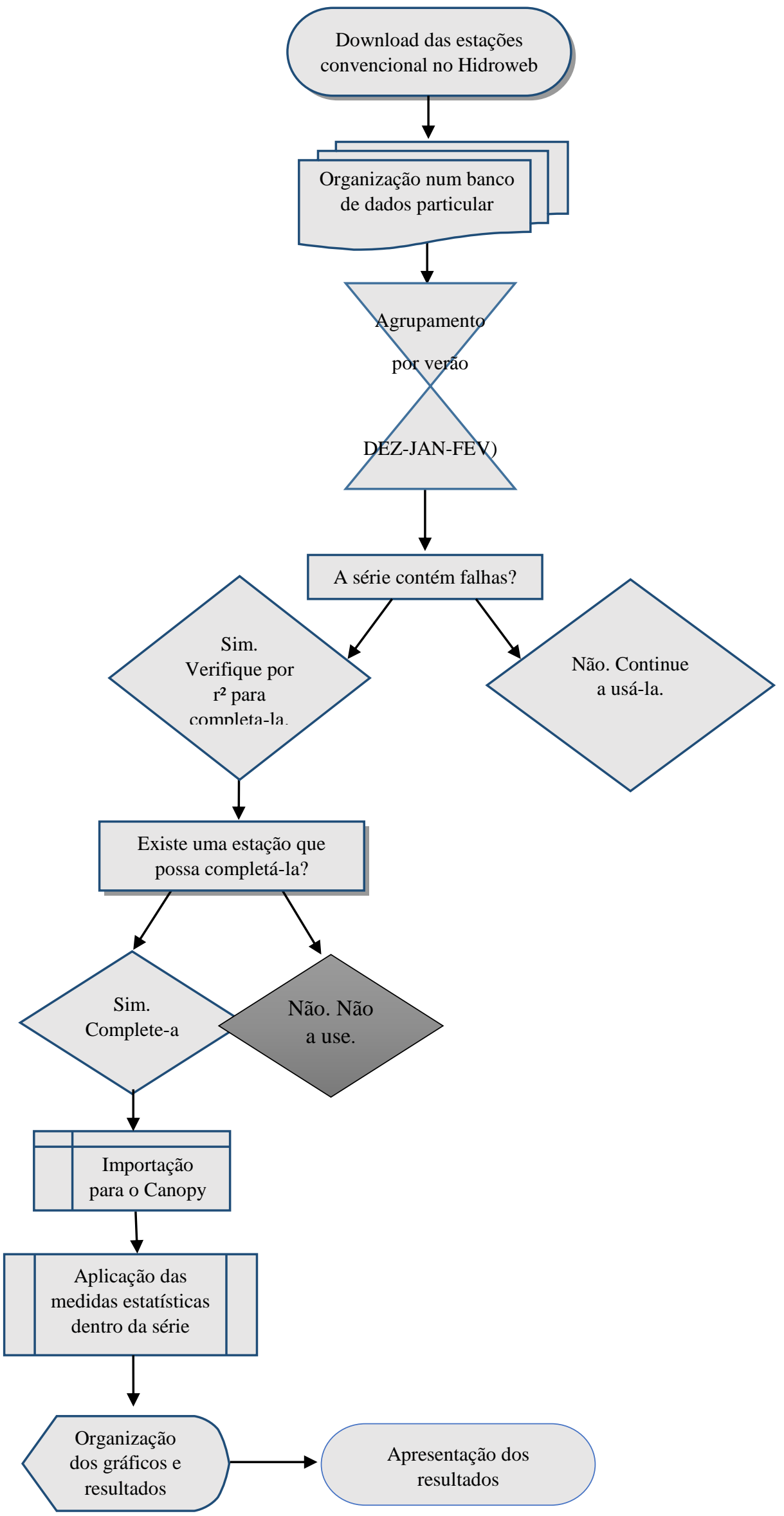


A partir dos resultados salvos em formato .csv foi possível apresentá-los em gráficos feitos no Excel para posterior análise dos dados.

\subsection{Identificação e descrição dos sistemas atmosféricos deflagradores do evento}

De acordo com a bibliografia consultada (AMBRIZZI, 2014; THE COMET, 2016) e, apresentada na Figura 2, o período de atuação dos sistemas atmosféricos deflagradores das fortes chuvas analisadas, compreende uma escala de dias até semanas. Para identificação da concomitância entre os sistemas atmosféricos e os impactos registrados utilizou-se o Boletim Climanálise.

O Climanálise é um boletim de análise climática feito pelo CPTEC-INPE no qual disponibiliza mensalmente uma análise dos sistemas atmosféricos atuantes no referido mês. Ele pode ser consultado e baixado pelo site http://climanalise.cptec.inpe.br/ rclimanl/boletim/ onde é possível escolher a edição em formato html ou .pdf bem como o mês e o ano a ser consultado. A figura 13 a seguir mostra o layout do site.

Figura 13. Layout do site Climanálise Boletim.

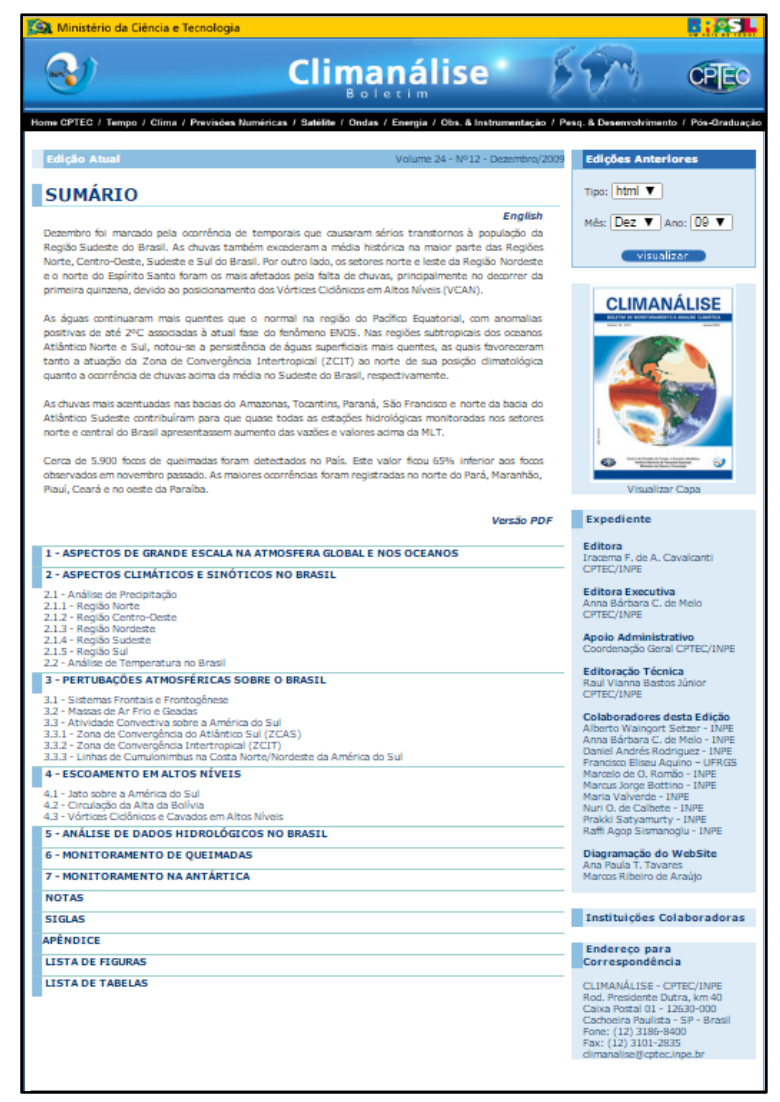

Fonte: INPE (2016). 
Foram consultados os seguintes boletins correspondentes com os meses e anos de ocorrências de impactos disponíveis no Banco de Dados de Desastres Naturais:

Quadro 2. Meses e ano dos boletins consultados.

\begin{tabular}{|l|l|}
\hline Mês & Ano \\
\hline Fevereiro & 2004 \\
\hline Janeiro & 2005 \\
\hline Abril & 2005 \\
\hline Fevereiro & 2006 \\
\hline Janeiro & 2007 \\
\hline Janeiro & 2008 \\
\hline Fevereiro & 2009 \\
\hline Dezembro & 2009 \\
\hline Janeiro & 2010 \\
\hline Dezembro & 2010 \\
\hline Janeiro & 2011 \\
\hline Novembro & 2011 \\
\hline Janeiro & 2013 \\
\hline
\end{tabular}

Fonte: Organizado pela autora (2016).

\subsubsection{Organização das informações por evento}

De forma a atingir o objetivo da pesquisa optou-se por organizar os resultados encontrados a partir de cada ocorrência registrada para então, identificar os sistemas e ponderar a quantidade de precipitação ocorrida com relação à climatologia da região. Em forma de fluxograma temos a seguinte organização das informações:

Figura 14. Configuração dos eventos analisados.

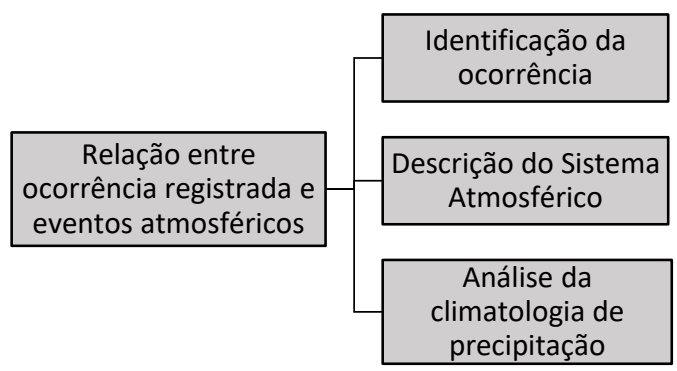

Fonte: Organizado pela autora (2017). 


\subsection{Caracterização da área de estudo}

Para a compreensão do contexto dos fatos ocorridos é necessário estudar a história e geografia do local. São aspectos importantes para a presente pesquisa a formação territorial, a paisagem local e a interação do homem com o ambiente. Serão abordados nesse subcapítulo tais aspectos de São Luiz do Paraitinga.

\subsubsection{Localização, povoamento e atividades econômicas}

Em pleno rio Paraitinga, localizado no sudeste do estado de São Paulo, nas coordenadas $23^{\circ}$ 13' 23" Sul e 45 18' 38", estabeleceu-se no contexto das expedições Bandeirantes, um ponto de comércio por onde escoava café e ouro mineiro. Desde então aquela região foi palco de diversas atividades econômicas.

Apesar de se ter registros sobre o local ser ponto de trocas e escoamento de produtos já no século XVII, foi em maio de 1769 , no século XVIII, que o povoado em si, foi fundado pelo sargento mor Manoel Antônio de Carvalho. No decorrer dos séculos e com o avanço das atividades agrícolas o pequeno povoado passou de vila em 1773 até ser elevada à categoria de cidade em 1873.

De acordo com Marchezini (2017), a partir da década de 1830 a região do Vale do Paraíba vivenciou um crescimento econômico em decorrência da monocultura cafeeira o que atraiu um grande fluxo migratório para a região e, inclusive, para São Luiz do Paraitinga. Sob a riqueza do café a população mais que triplicou em 50 anos, de 5.296 moradores existentes em 1836, passam a existir 17.368 habitantes no ano de 1886 . No entanto, da mesma forma que a população aumentou com o crescimento econômico, quando chegou a crise do café a população acabou diminuindo.De 1911 para 1940 a população decaiu de 25.166 moradores para 11.127.De acordo com o último censo do IBGE do ano de 2010 o município contava com 10.397 habitantes, já a estimativa para o ano de 2016 seria de 10.735 habitantes.

A evolução secular das atividades econômicas do Vale do Paraíba tem bastante relação com o escoamento de recursos naturais para o porto e o desenvolvimento da agricultura. Especificamente em São Luiz do Paraitinga o início das atividades econômicas se dá a partir do século XVII, enquanto a localidade era passagem de bandeirantes e tropas que levavam cargas e ouro que seriam enviados para a Europa. 
Já no século XVIII a população era caracterizada em sua maioria por famílias sem muitos bens, que se dedicavam à agricultura de sobrevivência, na qual os cereais (milho, arroz, feijão) eram os principais cultivos. O ciclo do café no ano de 1830 modificou a economia local, uma vez que propiciou a expansão e o acúmulo de riquezas de uns poucos proprietários mais abastados.

Além da monocultura cafeeira, outras culturas agrícolas permaneceram pelo século XIX, como por exemplo, os cereais, marcando a cidade como o "Celeiro do Vale". Havia também a produção de rapadura, beneficiamento de farinha e a produção de cachaça. $\mathrm{O}$ comércio da cidade também foi se desenvolvendo, já que era uma rota de circulação de pessoas.

Já no século XX, inicia-se no município uma pequena produção de policulturas (em contraposição com as monoculturas) e a pecuária leiteira, até hoje uma das principais fontes de renda da população de São Luiz do Paraitinga.

No século XXI, dá-se destaque econômico para o cultivo de eucalipto e o turismo, esse último em decorrência dos prédios históricos tombados pelo Conselho de Defesa do Patrimônio Histórico, Arqueológico, Artístico e Turístico do Estado de São Paulo (CONDEPHAAT) e o desenvolvimento de atividades relacionadas a ecoturismo.

Em 5 de julho de 2002 foi aprovada a Lei Estadual $n^{\circ} 11.197$ que assegura a cidade como Estância Turística (SANTOS, 2007). 
Figura 15. Plantações de eucalipto "emolduram" cenário de construções de arquitetura colonial do centro.

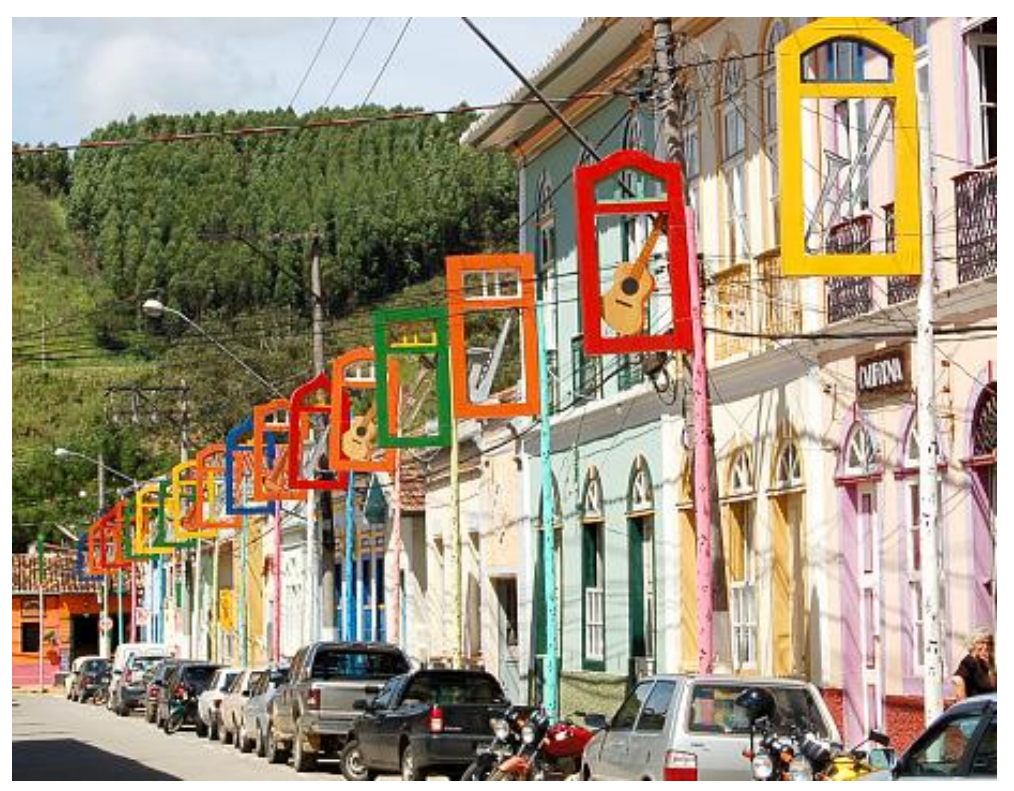

Fonte: Repórter Brasil (2009).

\subsubsection{Geomorfologia}

Moura, Jimenez-Rueda e Martins-Coelho (2006) publicou um trabalho no qual reúne descrições sobre o relevo, geologia e solo do Vale do Paraíba do Sul, região geomorfológica da área de estudo, sob a perspectiva de diversos autores.

Sobre os fatores determinantes para a morfogênese do terreno, os autores destacam a chuva e a alta amplitude térmica, fatores típicos de ambientes de clima tropical, quente e úmido, porém fatores biológicos e geológicos também devem ser considerados.

As altas amplitudes térmicas promovem a fragmentação das rochas e, a partir de pedaços menores, o intemperismo químico auxiliado pela presença da água, consegue agir com mais potencialidade transformando a rocha em solo. (LEINZ ${ }^{3}, 1995$ apud MOURA; JIMENEZRUEDA; MARTINS-COELHO, 2006; NIMER, 1989).

\footnotetext{
${ }^{3}$ LEINZ (1995) - LEINZ, V.; AMARAL S. E. Geologia geral, Editora Nacional, São Paulo, $12^{\circ}$ edição revisada, 400 p., 1995.
} 
De acordo com Ab'Saber ${ }^{4}$ (1966 apud MOURA; JIMENEZ-RUEDA; MARTINS-COELHO, 2006) o Vale do Paraíba está incluído no domínio de mares de morros, com grande decomposição das rochas e máxima presença de mamelonização topográfica; formas características de áreas tropicais úmidas.

Figura 16. São Luiz do Paraitinga situada no domínio de mares de morros.

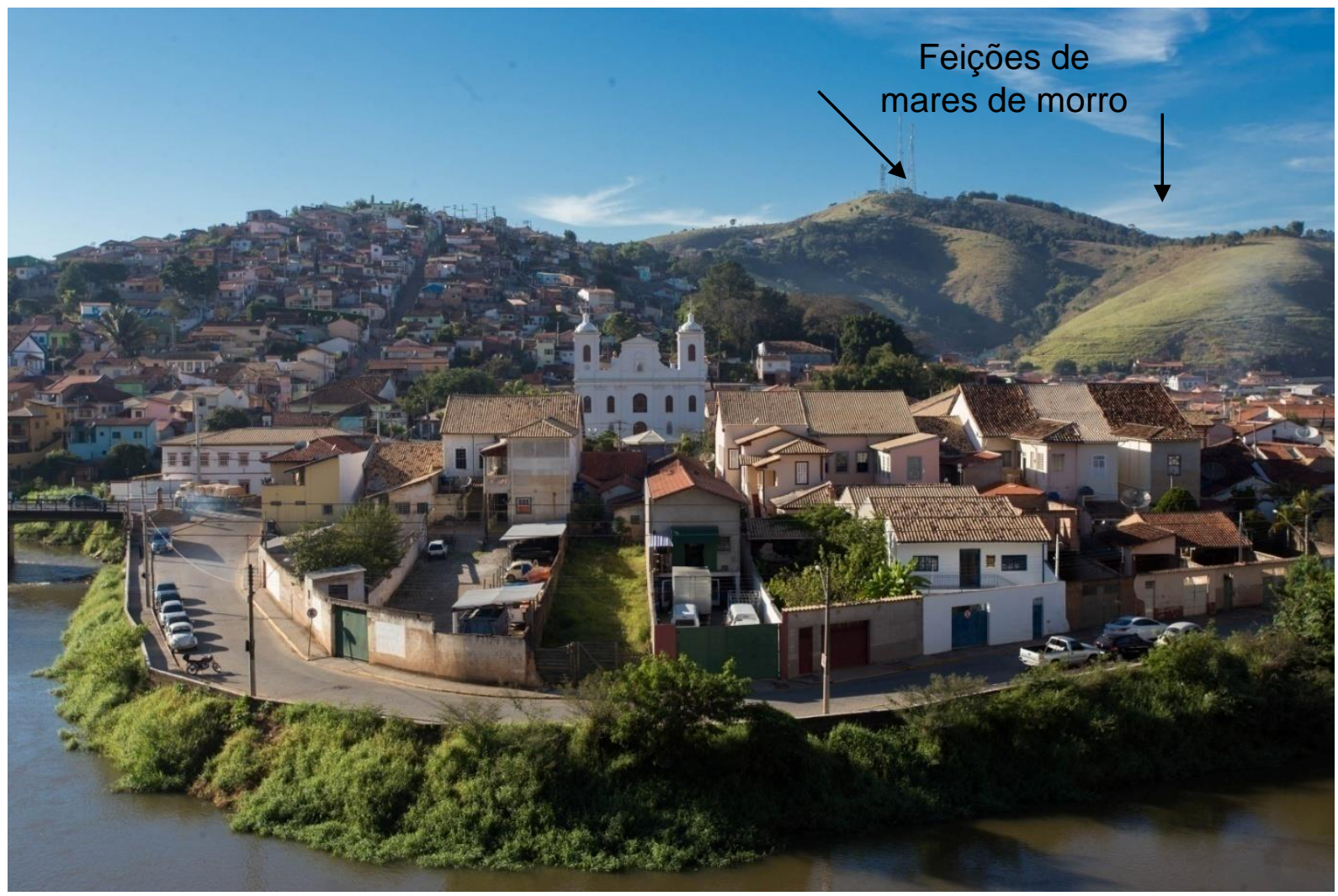

Fonte: FLICKR (2014).

Com base no mapa hipsométrico e no mapa de declividade apresentados respectivamente nas figuras 17 e 18 é possível identificar que o município de São Luiz do Paraitinga está localizado em altitudes de 650 a 850 metros, com declividades de $0 \%$ a $12 \%$ sendo relativo a Relevo plano (0\% a 3\%), Relevo suavemente ondulado (3\% a 5\%) e Relevo ondulado (5 a $12 \%)$.

Historicamente os povoados surgem nas margens dos rios em decorrência da disponibilidade de água, alimentos e vias de transporte hidrográfico. Isso aconteceu com São Luiz do Paraitinga também, e consequentemente a cidade fica vulnerável às enchentes e inundações do rio Paraitinga e desabamento de terras dos morros em seu entorno.

\footnotetext{
${ }^{4}$ AB'SABER (1996) - AB'SÁBER, A. N. O domínio dos mares de morro no Brasil. São Paulo, USP/Instituto de geografia, Série Geomorfologia, $N^{\circ}$ 2, 12p., 1969.
} 
Figura 17. Mapa hipsométrico de São Luiz do Paraitinga - SP.

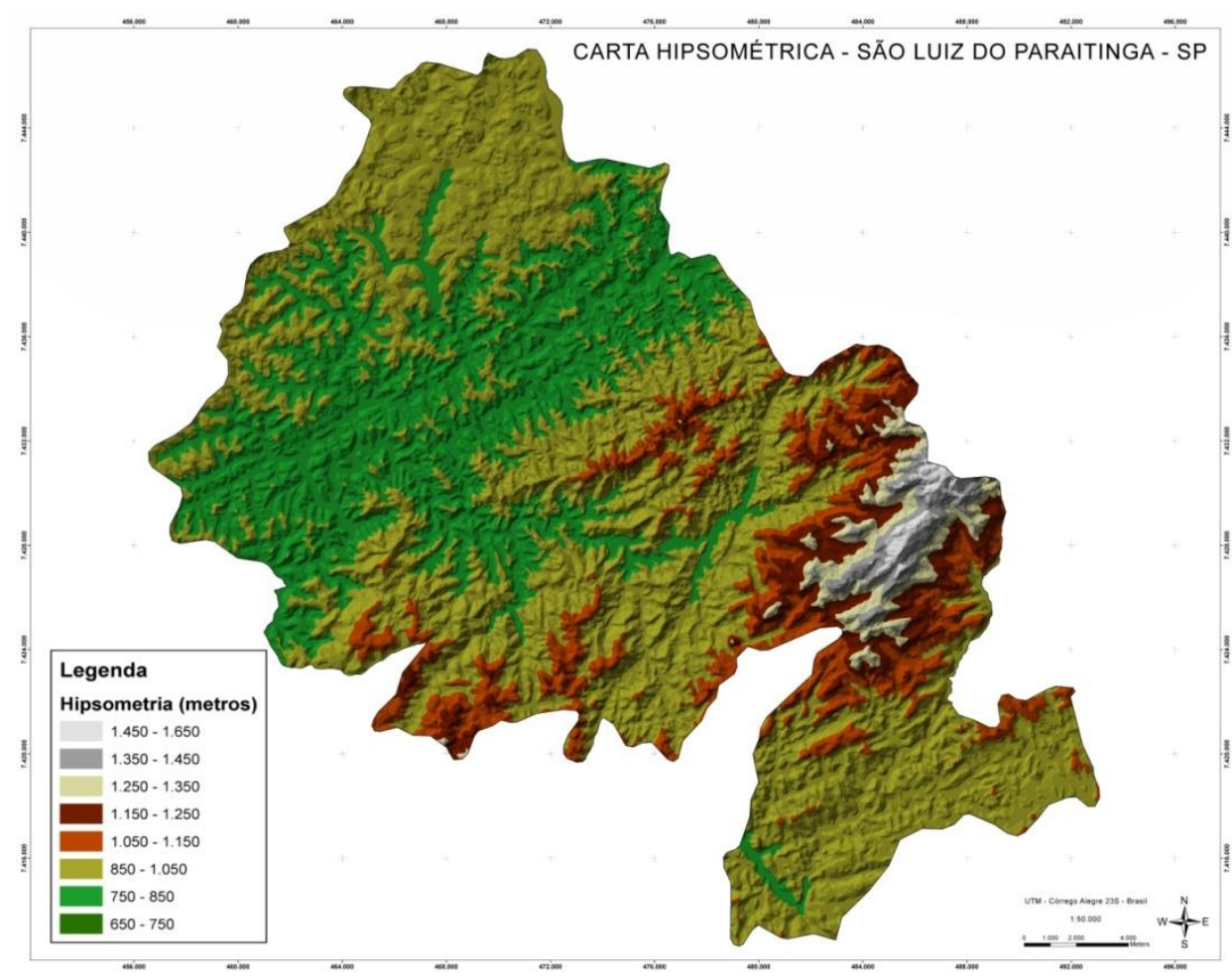

Fonte: Prefeitura Municipal de São Luiz do Paraitinga - SP (2010).

Figura 18. Mapa de declividade do município de São Luiz do Paraitinga - SP.

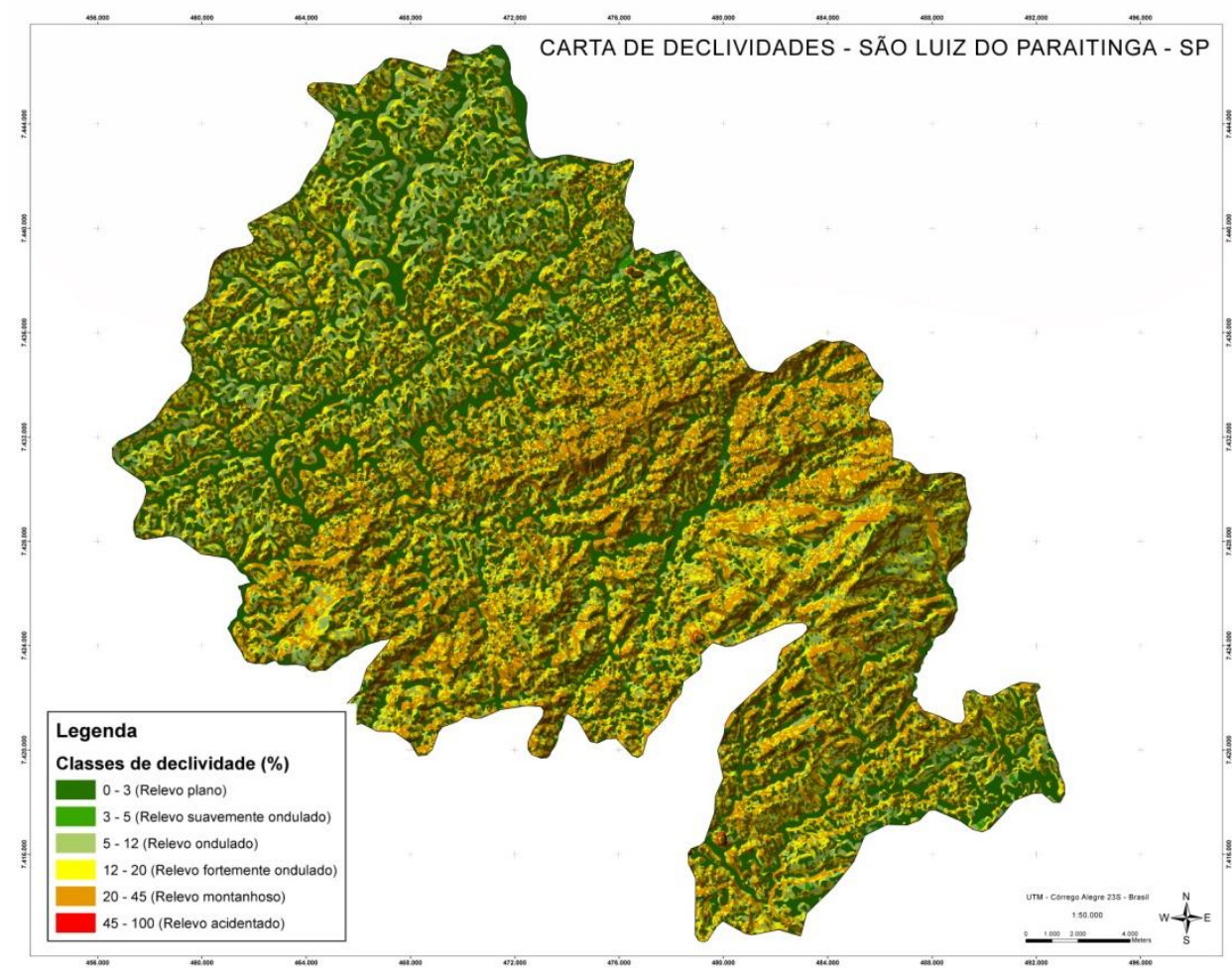

Fonte: Prefeitura Municipal de São Luiz do Paraitinga - SP (2010). 


\subsubsection{Clima}

No aspecto climático, de acordo com a literatura utilizada no Plano de Manejo do Parque Estadual da Serra do Mar (PESM) baseada em Monteiro (1973) e em Sant'Anna Neto (1990), entende-se que: “A dinâmica atmosférica, conjugada aos aspectos geográficos da área, produz climas que se caracterizam pela elevada pluviosidade e ritmo variável no tempo e no espaço" (INSTITUTO FLORESTAL, 2006, p. 49).

Monteiro (1973), também citado no Plano de Manejo do PESM, define o clima do Núcleo Santa Virgínia como "geneticamente ligado ao litoral norte, sazonalmente controlada pelos sistemas equatoriais e tropicais, e, regionalmente, chamado clima úmido das costas expostas à massa tropical atlântica" (INSTITUTO FLORESTAL, 2006, p. 49).

Ainda de acordo com o autor, no outono-inverno verifica-se uma diminuição das chuvas comparada à planície litorânea, isso porque o relevo atua como barreira para a umidade. A participação das massas polares é baixa, entre $30 \%$ a $40 \%$ ao ano e, a influência orográfica pode produzir pequenas chuvas, sob o domínio do Sistema Tropical, apesar deste tender à estabilidade e ao bom tempo. As chuvas de primavera-verão são ocasionadas, na maioria das vezes, pelo eixo reflexo da Frente Polar, que em anos secos de fraca atividade polar dá destaque para essa área em decorrência das chuvas que ocasiona.

Sant'Anna Neto (1990) define o clima da mesma área como "subzona Litoral Norte", na qual há atuação dos sistemas Tropical Atlântico e Tropical Atlântico Continentalizado e das frentes Polar atlântica, Polar Atlântica Estacionária e Polar Atlântica em Dissipação.

\subsubsection{Meio físico e impactos ambientais}

Ab'Sáber ${ }^{5}$ (1975apud MODENESI-GAUTTIERI et al., 2010, p.429) em seu estudo de impacto da Usina de Paraibuna e Barragem de Paraitinga já descrevia sobre alguns dos impactos na paisagem gerados pelas atividades antrópicas:

Antes do ciclo do café, as paisagens naturais da região correspondiam a um estágio de afeiçoamento de mamelonização e aflorestamento generalizado das vertentes, até níveis topográficos de 1.100 a $1.300 \mathrm{~m}$. Evidentemente as ações humanas que se prolongaram na área por um século e meio de atividade agrárias equivaleram a uma interrupção forçosa do estágio de evolução natural que a região vinha sofrendo. Após o ciclo do café que foi o

\footnotetext{
${ }^{5}$ AB’SABER (1975) - A Depressão Periférica Paulista: um setor das áreas de circundesnudação póscretácica na Bacia do Paraná. Geomorfologia, São Paulo, 15: 1-26, 1969.
} 
tema básico para o uso do solo em termos agrícolas, sucedeu-se a fase de implantação de atividades de pastagens, voltadas para a obtenção do leite (bacia leiteira do alto do Paraíba). O advento da expansão das pastagens completou o desmatamento iniciado no período cafeeiro, transformando o mar de morros florestado em um mar de morros predominantemente revestido por pastagens. Quando foram iniciadas as obras das barragens de Paraibuna e de Paraitinga, a paisagem regional possuía de $85 \%$ a $90 \%$ de pastagens nas vertentes e nos rios interflúvios arredondados dos morros, e apenas $5 \%$ a $15 \%$ de capoeiras e de capoeirões residuais situados nas mais diferentes posições topográficas.

Sobre a vegetação presente no município é possível verificar no Mapa da Cobertura Vegetal e Unidades de Conservação (Figura 19) disponibilizado no Plano Diretor e na imagem orbital do Google Earth (Figura 20) os tipos Capoeira, Reflorestamento, e Mata Atlântica onde, inclusive, está localizado o Parque Estadual da Serra do Mar (PESM), núcleo Santa Virgínia.

Figura 19. Mapa da cobertura vegetal e unidades de conservação de São Luiz do Paraitinga - SP.

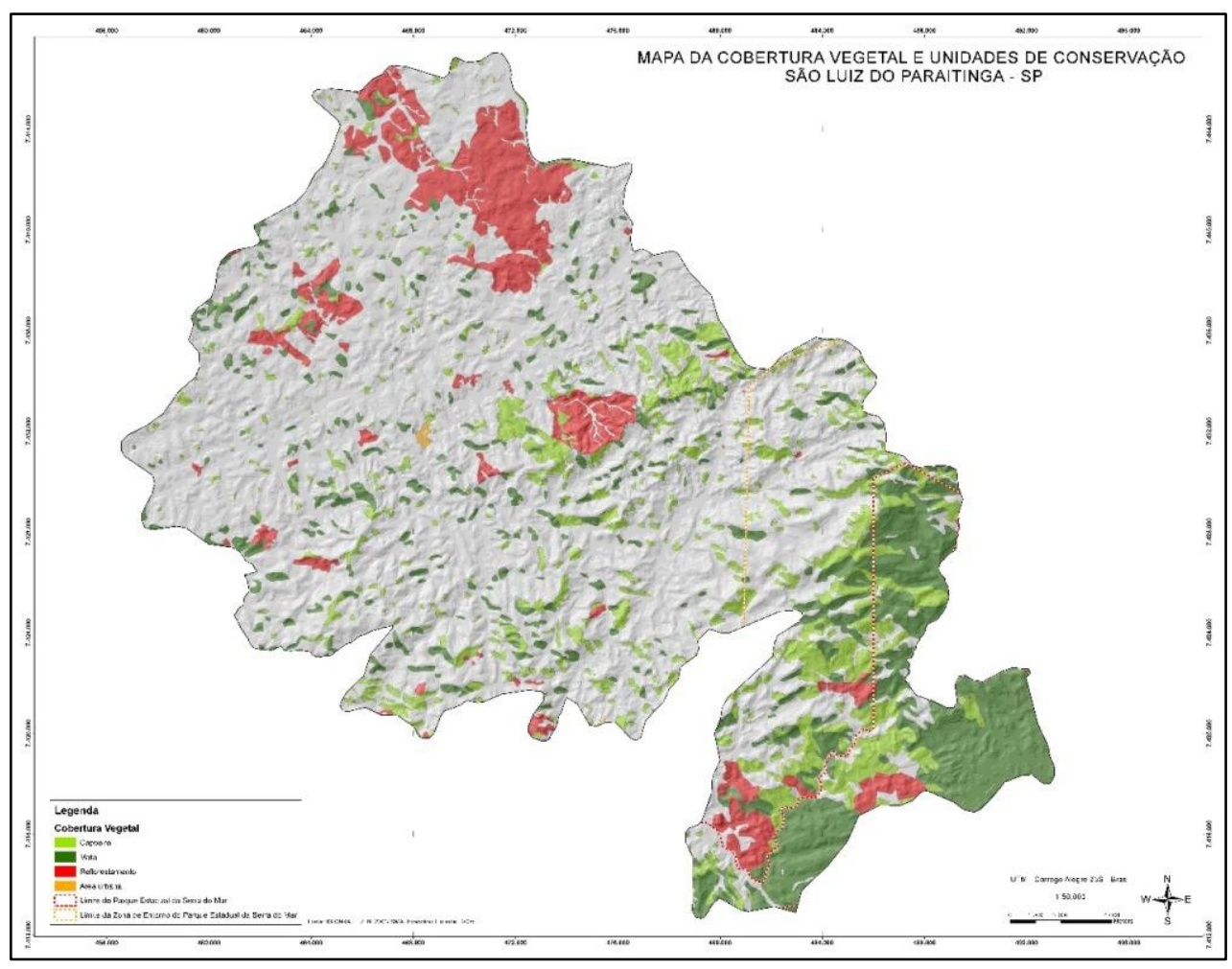

Fonte: Prefeitura Munucipal de São Luiz do Paraitinga - SP (2010). 
Figura 20. Delimitação do município de São Luiz do Paraitinga - SP.

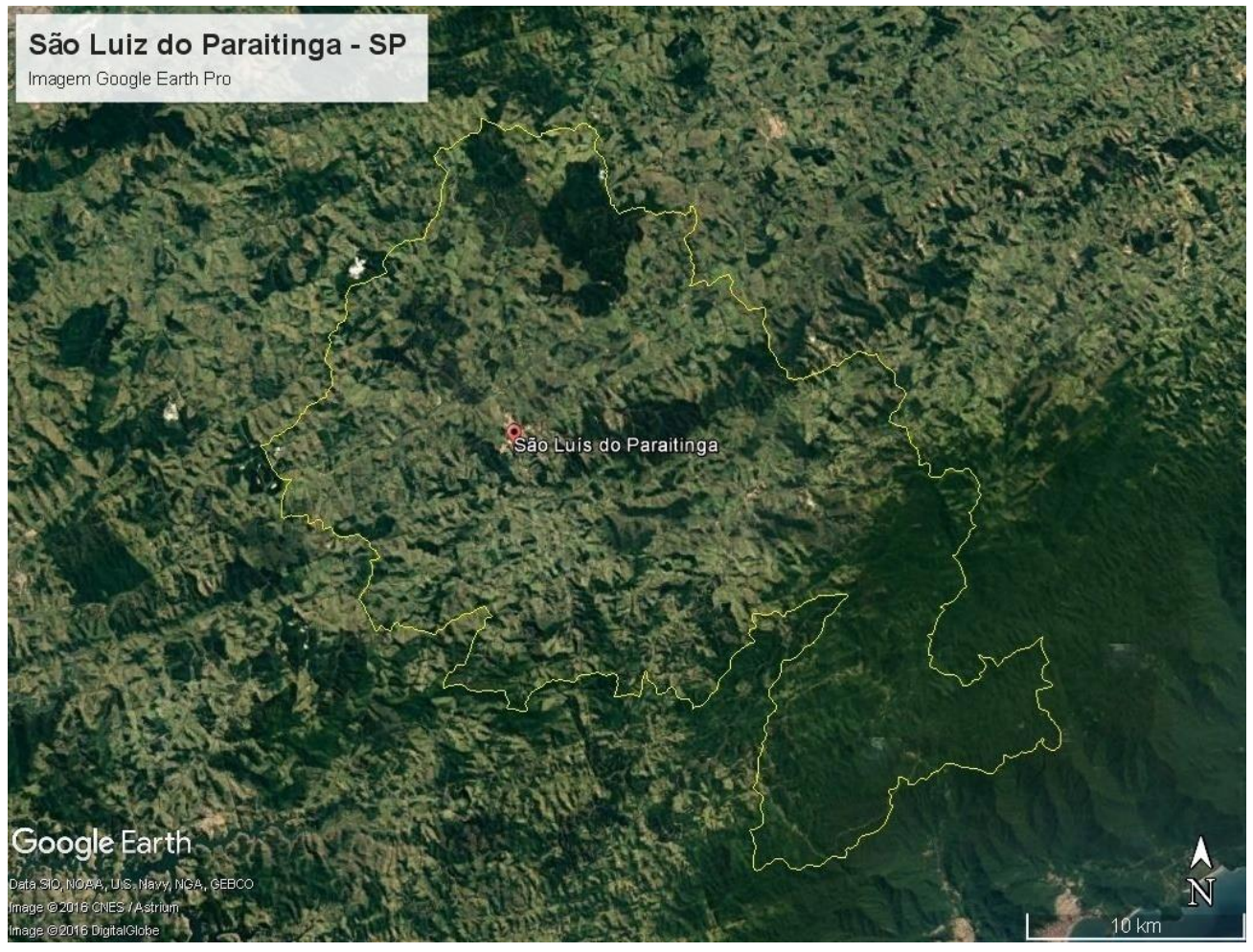

Fonte: Google Earth Pro (2017).

Além do aspecto ambiental, como manutenção de temperaturas amenas, estabilização das encostas, garantia da qualidade e quantidade da água e habitat para a biodiversidade, o Parque também influencia a economia dos núcleos urbanos localizados no seu entorno. Sua beleza cênica, as trilhas, cachoeiras e praias fazem parte da atividade turística desenvolvida ali, colaborando para sustentabilidade da região.

Em decorrência do desmatamento realizado desde o período colonial até os dias atuais, restaram apenas 7,6\% da cobertura original da Mata Atlântica (INSTITUTO FLORESTAL, 2006). O município de São Luiz do Paraitinga abrange parte do resquício desse bioma, o Parque Estadual da Serra do Mar. Seus remanescentes concentram-se nas regiões Sul e Sudeste do Brasil, recobrindo parte da Serra do Mar e da Mantiqueira, onde o relevo é acidentado e a infraestrutura de transporte não foi modernizada.

Do ponto de vista dos conservacionistas a Serra do Mar, por fazer parte do remanescente de Mata Atlântica, é considerada "hotspot" para conservação. Conceito criado em 1988 pelo ecólogo inglês Normam Myers, "hotspot” refere-se a uma área prioritária para conservação, pois é rica em biodiversidade e está ameaçada por atividades antrópicas (INSTITUTO FLORESTAL, 2006). 
O documento do Plano de Manejo do PESM destaca ainda a relação da floresta com os recursos hídricos. Estudos realizados no Laboratório de Hidrologia Florestal Walter Emmerich, localizado no Núcleo Cunha do Parque Estadual da Serra do Mar apontam que "o consumo de água da pela Mata Atlântica é substancialmente menor, com rendimento hídrico na ordem de $70 \%$, ou seja, $70 \%$ da precipitação que entra no sistema de uma microbaciadeixao na forma de escoamento pelo rio".

Ainda nesse sentido, o Plano cita pesquisas desenvolvidas no município de Cunha, as quais demonstraram que o custo do tratamento da água em áreas não florestadas é mais caro e menos eficaz do que o tratamento de água em mananciais protegidos por cobertura florestal e com menor interferência antrópica (INSTITUTO FLORESTAL, 2006).

\subsubsection{Espaço territorial}

$\mathrm{O}$ atual plano diretor participativo do município,disponibilizado para acessono site da prefeitura municipal, foi planejado e implementado pela LEI COMPLEMENTAR No ${ }^{\circ}$ 1.347, de 07 de janeiro de 2010.Esse documento teve que ser revisado em decorrência do estado de calamidade que a cidade passou após as chuvas intensas do verão de 2009/2010. Dessa forma, revisado pela LEI No 1.458 , de julho de 2011 o novo documento pretendia a atender às novas necessidades estruturais e da população. Essa nova versão contém o Macrozoneamento Urbano do município.

O Macrozoneamento urbano foi um instrumento importante para o replanejamento do uso e ocupação do solo dentro da área urbana do município de forma a diminuir os riscos e vulnerabilidades a possíveis desastres naturais, definindo as seguintes funções:

I. Zona de Preservação Arquitetônica, Urbanística e Paisagística - Z.P.A.U.P.;

II. Zona Preferencialmente Residencial - Z.P.R.;

III. Zona Industrial, de Serviços e Comércio - Z.I.S.C.;

IV. Zona Especial de Interesse Social - Z.E.I.S.;

V. Zonas de Projetos Especiais - Z.P.E.;

VI. Zonas Mista com incentivo à moradia - Z.M.

VII. Zona de Incentivo a Recuperação e Preservação Ambiental - Z.I.R.P.A.;

VIII. Distrito Agroindustrial;

IX. Zona Especial de Interesse Social e Ambiental - Z.E.IS. AMB. 
Instrumentos de planejamento de uso e ocupação da terra, como o Zoneamento Urbano, são fundamentais para a diminuição do risco e vulnerabilidade na cidade. Autores como Casco et al. (2011) e Nunes (2009) afirmam que o evento de precipitação ou o regime fluvial de uma bacia inundável, poderia não ser uma ameaça para a cidade e seus habitantes se houvesse o melhor planejamento evitando-se ocupação em áreas de risco.

Figura 21. Funções Urbanas de São Luiz do Paraitinga - SP.

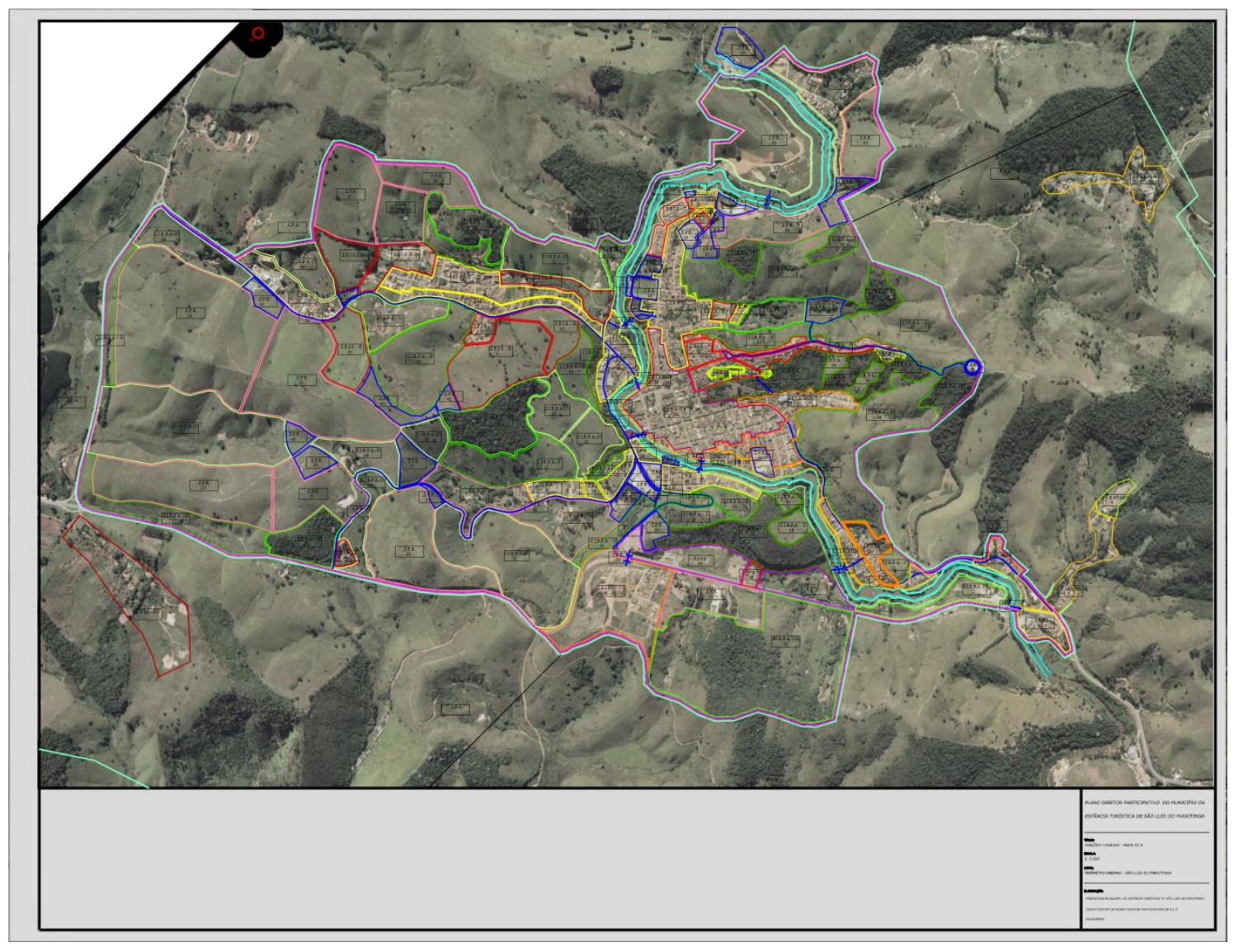

Fonte: Plano Diretor Participativo do Município da Estância Turística de São Luis do Paraitinga, (2010).

\subsection{Resultados e discussões}

A tabela 4 apresentada a seguir é resultante da busca pelas ocorrências registradas no Banco de Dados de Desastres Naturais do IPMet e organizadas de maneira que melhor identifique o evento em análise. De acordo com a metodologia utilizada houve interesse nas ocorrências dentro da escala espaço-temporal dos meses de dezembro, janeiro e fevereiro dos anos disponíveis no banco de dados correspondente ao ínterim de 1995 a 2014 e contemporâneos com a série histórica da pesquisa. As ocorrências registradas em datas próximas foram 
consideradas o mesmo evento, dessa maneira contabilizou-se 9 eventos de impactos causados por precipitação.

A descrição dos eventos em suas especificidades encontra-se no subitem 4.5.1., bem como a caracterização atmosférica referente ao mês do evento. Posteriormente, a climatologia da precipitação encontra-se apresentada no subitem 4.5.2., por meio das medidas de total de acumulado, desvio da média e histograma indicando quantos verões houveram no determinado intervalo de classes de milímetros de precipitação e quantos eventos de impacto houveram naqueles intervalos de classe. Os eventos foram organizados por ordem cronológica, dessa forma a primeira barra destacada em vermelho nos gráficos de Total acumulado e Desvio da média correspondem ao primeiro evento e assim sucessivamente até a última barra destacada.

Tabela 4. Ocorrências registradas no Banco de Dados de Desastres Naturais.

\begin{tabular}{|c|c|c|c|c|c|c|c|c|}
\hline $\begin{array}{l}N^{\circ} \text { do } \\
\text { Evento }\end{array}$ & Data & Hora & $\begin{array}{c}\text { Fenôme } \\
\text { no }\end{array}$ & Duração & $\begin{array}{l}\text { Ocorrências/ } \\
\text { Danos }\end{array}$ & Total de Danos & $\begin{array}{c}\text { Total } \\
\text { de } \\
\text { Vitimas }\end{array}$ & Fonte \\
\hline 1 & $24 / 02 / 04$ & -1 & 3 & -1 & $31,32,33$ & -1 & -1 & $\begin{array}{l}\text { Defesa } \\
\text { Civil }\end{array}$ \\
\hline 2 & $24 / 01 / 05$ & -1 & 7 & -1 & $21,26,28$ & -1 & -1 & $\begin{array}{l}\text { Defesa } \\
\text { Civil }\end{array}$ \\
\hline \multirow{2}{*}{3} & $12 / 02 / 06$ & $\begin{array}{c}00 \mathrm{~h} 4 \\
0\end{array}$ & 7 & -1 & 31,34 & -1 & -1 & $\begin{array}{l}\text { Defesa } \\
\text { Civil }\end{array}$ \\
\hline & $22 / 02 / 06$ & $\begin{array}{c}16 \mathrm{~h} 3 \\
0\end{array}$ & 3 & -1 & $20,31,33$ & -1 & -1 & $\begin{array}{l}\text { Defesa } \\
\text { Civil }\end{array}$ \\
\hline \multirow{2}{*}{4} & $26 / 12 / 06$ & $\begin{array}{c}20 \mathrm{~h} 5 \\
3\end{array}$ & 3 & $1 \mathrm{~h}$ & 34,43 & -1 & -1 & $\begin{array}{l}\text { Defesa } \\
\text { Civil }\end{array}$ \\
\hline & 03/01/07 & -1 & 7 & 3 dias & 21,33 & -1 & -1 & $\begin{array}{l}\text { Defesa } \\
\text { Civil }\end{array}$ \\
\hline 5 & 03/01/08 & $\begin{array}{l}\text { Madr } \\
\text { ugad } \\
\text { a }\end{array}$ & 3 & -1 & $21,26,28,30,33$ & -1 & -1 & $\begin{array}{c}\text { Defesa } \\
\text { Civil }\end{array}$ \\
\hline 6 & $15 / 02 / 09$ & $\begin{array}{c}01 \mathrm{~h} 2 \\
0\end{array}$ & 3 & $\begin{array}{l}\text { Longa } \\
\text { duração }\end{array}$ & $\begin{array}{c}20(62), 21(10), 31 \\
33(25)\end{array}$ & 97 & 72 & $\begin{array}{l}\text { Defesa } \\
\text { Civil }\end{array}$ \\
\hline \multirow[b]{4}{*}{7} & 08/12/09 & -1 & 3,8 & -1 & $\begin{array}{c}21,25,26,31(17), 3 \\
3,34\end{array}$ & 17 & -1 & $\begin{array}{l}\text { Defesa } \\
\text { Civil }\end{array}$ \\
\hline & 09/12/09 & -1 & 7,8 & -1 & $21,26,28,33$ & -1 & -1 & $\begin{array}{l}\text { Defesa } \\
\text { Civil }\end{array}$ \\
\hline & $10 / 12 / 09$ & $\begin{array}{c}17 \mathrm{~h} 1 \\
5\end{array}$ & 7,8 & -1 & $\begin{array}{c}21,26,28,31,32,34 \\
, 43\end{array}$ & -1 & -1 & $\begin{array}{l}\text { Defesa } \\
\text { Civil }\end{array}$ \\
\hline & $\begin{array}{l}31 / 12 / 09 \\
01 / 01 / 10\end{array}$ & $\begin{array}{l}\text { Noite } \\
\text { e dia }\end{array}$ & $3,7,8$ & -1 & $\begin{array}{c}20(4000), 21(5000 \\
), 22(2), 23(1), 24,2 \\
6,27,31(12), 33(84 \\
4), 37,43,48\end{array}$ & 9859 & 9003 & $\begin{array}{l}\text { Defesa } \\
\text { Civil }\end{array}$ \\
\hline \multirow{3}{*}{8} & $03 / 01 / 10$ & $\underset{\tilde{a}}{\operatorname{Manh}}$ & 3 & -1 & $23(1), 26,27,31,46$ & 1 & 1 & G1 \\
\hline & $19 / 12 / 10$ & $\begin{array}{c}14 \mathrm{~h} 3 \\
0\end{array}$ & 3,8 & $1 \mathrm{~h}$ & $26,33(20)$ & 20 & -1 & $\begin{array}{l}\text { Defesa } \\
\text { Civil }\end{array}$ \\
\hline & $08 / 01 / 11$ & $\begin{array}{c}18 \mathrm{~h} 0 \\
0\end{array}$ & 3 & $40 \mathrm{~min}$ & $24(3), 30,33(43)$ & 46 & -1 & $\begin{array}{l}\text { Defesa } \\
\text { Civil }\end{array}$ \\
\hline 9 & $11 / 01 / 13$ & $\begin{array}{c}\text { 18:00 } \\
\mathrm{h}\end{array}$ & 8 & $\begin{array}{l}\text { Longa } \\
\text { duração }\end{array}$ & $21(26), 26,28$ & 26 & 26 & $\begin{array}{l}\text { Defesa } \\
\text { Civil }\end{array}$ \\
\hline
\end{tabular}

Fonte: Adaptado de Banco de Dados de Desastres Naturais IPMet, 2016. 


\subsubsection{Descrição dos eventos}

Em seguida é apresentada a análise detalhada de cada evento contendo a descrição do impacto registrado, os sistemas atmosféricos atuantes e a estatística descritiva dos valores de precipitação comparando o verão de ocorrência do evento com os valores da série histórica de 1982 a 2014.

Quadro 3. Evento de impacto pluvial 1 - verão 2003/2004.

\begin{tabular}{|c|c|c|c|c|c|c|}
\hline $\begin{array}{c}\mathbf{N}^{\mathbf{0}} \text { do } \\
\text { Evento }\end{array}$ & Data & Fenômeno & Ocorrências/Danos & $\begin{array}{c}\text { Total de } \\
\text { danos }\end{array}$ & $\begin{array}{c}\text { Total de } \\
\text { Vítimas }\end{array}$ & Fonte \\
\hline 1 & $\begin{array}{c}24 \\
\text { fev } \\
2004\end{array}$ & $\begin{array}{c}\text { Chuvas } \\
\text { Fortes }\end{array}$ & $\begin{array}{c}\text { Deslizamento de terra; } \\
\text { Queda de muro; } \\
\text { Desabamentos/Rachadura/ } \\
\text { Danos em Imóveis. }\end{array}$ & $\begin{array}{c}\text { Sem } \\
\text { dados }\end{array}$ & $\begin{array}{c}\text { Sem } \\
\text { dados }\end{array}$ & $\begin{array}{c}\text { Defes } \\
\text { a Civil }\end{array}$ \\
\hline
\end{tabular}

Fonte: Organizado pela autora (2016).

De acordo com o CLIMANÁLISE de fevereiro de 2004 foi o avanço das frentes frias e a configuração de dois episódios de ZCAS que colaboraram para o evento de chuvas fortes neste mês.

O primeiro episódio de ZCAS observado se deu entre os dias 07 e 11 favorecendo o aumento da atividade convectiva principalmente sobre o norte da Região Centro-Oeste, a fronteira de Minas Gerais com a Bahia e o Espírito Santo. O segundo, ocorrido entre os dias 20 e 24, o qual teve maior influência sobre o município de São Luiz do Paraitinga, atingindo desde o estado de Minas Gerais, São Paulo e centro-sul do Rio de Janeiro. O boletim destaca também a persistência da Alta da Bolívia e do Vórtice do Nordeste em altos níveis, o que colabora para o padrão estacionário da ZCAS.

Sobre as massas de ar frio, o CLIMANÁLISE aponta cinco episódios A primeira iniciou no dia 05 atingindo o interior da Região Sul e no sul do Mato Grosso do Sul nos dias 06 e 07, mas foi só no dia 08 até 10 que a massa de ar permaneceu com seu centro no oceano e proporcionou declínio de temperatura na faixa leste da Região Sudeste.

A segunda e a terceira massa de ar frio atuou na Região Sul do Brasil e deslocou-se para o oceano, respectivamente nos dias 15 e no dia 19. A quarta massa de ar frio, mais próxima ao dia da ocorrência, atuou no período de 22 a 25, posicionando-se sobre o Oceano Atlântico no dia 26. A quinta massa de ar frio observada atuou no Rio Grande do Sul do dia 28 até o dia 30. 
As medidas estatísticas aplicadas na série de verões das quatro estações pluviométricas analisadas mostraram que, apesar do valor precipitado ter sido acima da média, os eventos são recorrentes, aparecendo na primeira e segunda maior frequência nos histogramas.

Quadro 4. Evento de impacto pluvial 2 - verão 2004/2005.

\begin{tabular}{|c|c|c|c|c|c|c|}
\hline $\begin{array}{c}\mathbf{N}^{\mathbf{0}} \text { do } \\
\text { Evento }\end{array}$ & Data & Fenômeno & Ocorrencias/Danos & $\begin{array}{c}\text { Total de } \\
\text { Danos }\end{array}$ & $\begin{array}{c}\text { Total de } \\
\text { Vitimas }\end{array}$ & Fonte \\
\hline 2 & $\begin{array}{c}24 \text { jan } \\
2005\end{array}$ & $\begin{array}{c}\text { Frente fria e } \\
\text { chuvas } \\
\text { contínuas }\end{array}$ & $\begin{array}{c}\text { Desalojado(s), } \\
\text { Transbordamento de Rios } \\
\text { e Córregos, Inundações } \\
\text { Graduais. }\end{array}$ & Sem dados & $\begin{array}{c}\text { Sem } \\
\text { dados }\end{array}$ & $\begin{array}{c}\text { Defes } \\
\text { a } \\
\text { Civil }\end{array}$ \\
\hline
\end{tabular}

Fonte: Organizado pela autora (2016).

O Boletim CLIMANÁLISE apontou a atuação de sistemas frontais, a configuração de um episódio de ZCAS e o desenvolvimento de áreas de instabilidade ao longo do mês de janeiro de 2005 como sistemas produtores de chuvas mais intensas na área de estudo. Inclusive no sul de Minas Gerais, no Rio de Janeiro e no resto do estado de São Paulo.

No dia 17, um VCAN formou-se próximo ao litoral de Pernambuco e deslocou-se para o interior do Nordeste e norte de Minas Gerais, onde permaneceu até o dia 24, contribuindo para a formação do único episódio de ZCAS deste mês, esse sistema, por sua vez, atuou entre os dias 17 e 21.

De acordo com o boletim climático, a Alta da Bolívia e o vórtice ciclônico sobre a Região Nordeste do Brasil foram ressaltados por um escoamento de $200 \mathrm{hPa}$. Sobre os sistemas frontais, foram identificados 4 sistemas atuantes, sendo que no dia 20, um sistema de baixa pressão, que atuou desde a superfície até os níveis médios da atmosfera, ingressou pelo Rio Grande do Sul e deslocou-se para o oceano, onde interagiu e intensificou outro sistema frontal que estava posicionado em Iguape-SP, a partir daí foram registradas chuvas intensas em São Paulo, no sul de Minas Gerais e no Rio de Janeiro. De 16 a 21, as frentes permaneceram semi-estacionárias sobre os Estados de São Paulo e Rio de Janeiro, caracterizando o único episódio de ZCAS deste mês.

Sobre as medidas estatísticas, observa-se que três estações (02345017, 02345065 e 02345067$)$ demonstram esse verão com precipitações abaixo da média para a série histórica analisada, e a estação 02345175 demonstra esse verão com precipitações um pouco acima da média. Com relação à frequência de ocorrência de valores tem-se que para os valores das estações 02345065, 02345067 e 02345175 ficaram entre as segundas maiores ocorrências, enquanto 
que a estação 02345017 apresentou o evento como a primeira menor ocorrência dentro da série histórica.

Quadro 5. Evento de impacto pluvial 3 - verão 2005/2006.

\begin{tabular}{|c|c|c|c|c|c|c|}
\hline $\begin{array}{l}\mathrm{N}^{\circ} \text { do } \\
\text { Evento }\end{array}$ & Data & Fenômeno & Ocorrências/Danos & $\begin{array}{c}\text { Total de } \\
\text { Danos }\end{array}$ & $\begin{array}{l}\text { Total de } \\
\text { Vitimas }\end{array}$ & Fonte \\
\hline \multirow{2}{*}{ 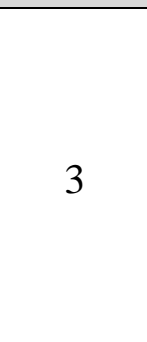 } & $\begin{array}{l}12 \mathrm{fev} \\
2006\end{array}$ & $\begin{array}{c}\text { Frente } \\
\text { fria/chuvas } \\
\text { contínuas }\end{array}$ & $\begin{array}{l}\text { Deslizamento de terra; } \\
\text { Congestionamento/Inter } \\
\text { dição de Via Pública }\end{array}$ & $\begin{array}{c}\text { Sem } \\
\text { dados }\end{array}$ & $\begin{array}{l}\text { Sem } \\
\text { dados }\end{array}$ & $\begin{array}{c}\text { Defesa } \\
\text { Civil }\end{array}$ \\
\hline & $\begin{array}{c}22 \mathrm{fev} \\
2006\end{array}$ & Chuvas Fortes & $\begin{array}{l}\text { Desabrigado(s); } \\
\text { Deslizamento de terra; } \\
\text { Desabamentos/Rachadu } \\
\text { ra/Danos em Imóveis }\end{array}$ & $\begin{array}{c}\text { Sem } \\
\text { dados }\end{array}$ & $\begin{array}{c}\text { Sem } \\
\text { dados }\end{array}$ & $\begin{array}{c}\text { Defesa } \\
\text { Civil }\end{array}$ \\
\hline
\end{tabular}

Fonte: Organizado pela autora (2016).

De acordo com o boletim climático CLIMANÁLISE do mês de fevereiro de 2006 foram observados dois episódios de ZCAS, o primeiro atuante entre os dias 27/01e dia 02/02 e o segundo ocorreu entre os dias09/02 e 13/02 e, apesar de ter se configurado fisicamente igual ao modelo conceitual já conhecido o próprio boletim destaca a ocorrência de fortes pancadas de chuva, em particular sobre o Estado de São Paulo, com perdas humanas e materiais.

Além da atuação da ZCAS, três sistemas frontais ingressaram no país, o sistema frontal que atuava no final domês de janeiro permaneceu estacionário no litoraldo Estado de São Paulo e em Cuiabá-MT, nosdias 01 e 02 do mês de fevereiro. Chuvas convectivas intensas foram produzidas em decorrência desse sistema.

As estatísticas entre as estações para esse evento em específico apresentaram-se diferenciadas uma das outras, diferente dos outros eventos. Não foi objetivo dessa pesquisa buscar entender o porquê disso, uma vez que, para os outros eventos, as estações apresentaram valores mais congruentes entre si. As estações 02345017 e 02345175 apontaram valores acima da média para o verão analisado, já as estações 02345065 e 0234567 apontaram valores abaixo da média com relação à série histórica. As frequências desses tipos de eventos apresentaram-se bem distintas para cada estação utilizada: na estação 02345017 a classe na qual ficou alocado esse evento foi a da segunda maior frequência, já na estação 02345065 a classe foi referente àprimeira maior frequência, na estação 02345067 a classe do histograma que pertence esse evento é a de terceira maior frequência, já a estação 02345175 o evento pertence à classe de menorfrequência. 
Quadro 6. Evento de impacto pluvial 4 - verão 2006/2007.

\begin{tabular}{|c|c|c|c|c|c|c|}
\hline $\begin{array}{c}\mathbf{N}^{0} \text { do } \\
\text { Evento }\end{array}$ & Data & Fenômeno & Ocorrências/Danos & $\begin{array}{c}\text { Total de } \\
\text { Danos }\end{array}$ & $\begin{array}{l}\text { Total de } \\
\text { Vitimas }\end{array}$ & Fonte \\
\hline \multirow[t]{2}{*}{4} & $\begin{array}{c}26 \mathrm{dez} \\
2006\end{array}$ & Chuvas fortes & $\begin{array}{l}\text { Congestionamento/Interdiç } \\
\text { ão de Via Pública; } \\
\text { Escorregamento de } \\
\text { Encosta. }\end{array}$ & $\begin{array}{c}\text { Sem } \\
\text { dados }\end{array}$ & Sem dados & $\begin{array}{c}\text { Defesa } \\
\text { Civil }\end{array}$ \\
\hline & $\begin{array}{c}03 \text { jan } \\
2007\end{array}$ & $\begin{array}{c}\text { Frente } \\
\text { fria/chuvas } \\
\text { contínuas }\end{array}$ & $\begin{array}{c}\text { Desalojados; } \\
\text { Desabamentos/Rachadura/ } \\
\text { Danos em Imóveis. }\end{array}$ & $\begin{array}{c}\text { Sem } \\
\text { dados }\end{array}$ & Sem dados & $\begin{array}{c}\text { Defesa } \\
\text { Civil }\end{array}$ \\
\hline
\end{tabular}

Fonte: Organizado pela autora (2016).

Optou-se por fazer a descrição dos sistemas atmosféricos atuantes durante tais ocorrências simultaneamente em decorrência da proximidade das datas.

O Boletim da CLIMANÁLISE de dezembro de 2006 apontou a atuação de dois episódios de ZCAS o qual ocasionou perdas materiais e humanas não só em São Luiz do Paraitinga, mas também em cidades do Rio de Janeiro, Minas Gerais e São Paulo.

Em janeiro, o Boletim atestou a atuação de quatro frentes frias no Brasil que se instalaram sobre o Oceano Atlântico contribuindo para a caracterização dos dois episódios de ZCAS, dos quais os dois primeiros antecederam à ocorrência registrada e, fisicamente falando, apresentaram características clássicas, associados a ciclones extratropicais.

Em específico, a primeira frente foi intensificada pelo cavado em 500 hPae pelo vórtice ciclônico em $200 \mathrm{hPa}$, cujo centro encontrava-se posicionado adjacente à costa sudeste do Brasil. A segunda frente fria acoplou-se ao sistema frontal posicionado sobre o oceano mantendo a atividade convectiva associada ao primeiro episódio de ZCAS.

Sobre as duas ZCAS atuantes em janeiro o boletim aponta que as características dinâmicas analisadas em ambos os episódios estão coerentes com o modelo conceitual de ZCAS. A primeiraatuou desde 27/12/06 até 16/01/07 em conjunto com um vórtice ciclônico próximo à região Sudeste que contribuiu para maior intensidade do sistema.

As estações 02345017, 02345067 e 02345175 mostraram valores abaixo da média com relação à série histórica, já a estação 02345065 apresentou valores acima da média para a série histórica. Com relação à frequência de ocorrência de eventos de precipitação desse tipo, a estação 02345067 apresenta o evento como a terceira menor frequência, considerando que o valor precipitado ficou muito abaixo da média $(246 \mathrm{~mm})$, já as outras estações apresentam o evento como a primeira maior frequência dentro da série. 
Quadro 7. Evento de impacto pluvial 5 - verão 2007/2008.

\begin{tabular}{|c|c|c|c|c|c|c|}
\hline $\begin{array}{c}\mathbf{N}^{\mathbf{0}} \text { do } \\
\text { Evento }\end{array}$ & Data & Fenômeno & Ocorrências/Danos & $\begin{array}{c}\text { Total de } \\
\text { Danos }\end{array}$ & $\begin{array}{c}\text { Total de } \\
\text { Vitimas }\end{array}$ & Fonte \\
\hline 5 & 3 jan & Chuvas fortes & $\begin{array}{c}\text { Desalojado(s); } \\
\text { Transbordamento de } \\
\text { Rios e Córregos; } \\
\text { Inundações Graduais; } \\
\text { Alagamentos; } \\
\text { Desabamentos/Rachadur } \\
\text { a/Danos em Imóveis. }\end{array}$ & $\begin{array}{c}\text { Sem } \\
\text { dados }\end{array}$ & Sem dados & $\begin{array}{c}\text { Defesa } \\
\text { Civil }\end{array}$ \\
\hline
\end{tabular}

Fonte: Organizado pela autora (2016).

Para compreender as ocorrências descritas acima, optou-se por consultar o Boletim CLIMANÁLISE de dezembro de 2007 em decorrência da proximidade da data.

De acordo com o Boletim os valores de precipitação ficaram abaixo da média histórica para esse mês, no entanto ocorreram alguns episódios extemos associados à passagem do primeiro sistema frontal e três episódios de ZCAS, ocasionando chuvas intensas e rajadas de vento nas regiões Sul e Sudeste. O primeiro evento de ZCAS teve seu início em 27 de novembro e terminou no dia 02 de dezembro, atuando principalmente sobre o norte da Região Sudeste e o centro-sul da Região Nordeste. O segundo episódio configurou-se entre os dias 13 e 15 e, o terceiro, entre os dias 19 e 24 desse mesmo mês.

Já no mês de janeiro de 2008, fisicamente falando, as temperaturas elevadas e o transporte de umidade em direção ao continente sul-americano foram responsáveis pela ocorrência de chuvas intensas, raios e granizo em grande parte do Brasil. Quanto aos sistemas atmosféricos associados às chuvas destaca-se a atuação da Zona de Convergência do Atlântico Sul, da Alta da Bolívia, áreas de instabilidade e massas de ar frio.

Quanto à análise estatística desse evento, as quatro estações pluviométricas analisadas apresentaram valores um pouco abaixo da média e as primeiras e segunda maiores frequência de ocorrência dessa quantidade de precipitação. 
Quadro 8. Evento de impacto pluvial 6 - verão 2008/2009.

\begin{tabular}{|c|c|c|c|c|c|c|}
\hline $\begin{array}{c}N^{\circ} \text { do } \\
\text { Evento }\end{array}$ & Data & Fenomeno & Ocorrencias/Danos & $\begin{array}{c}\text { Total de } \\
\text { Danos }\end{array}$ & $\begin{array}{c}\text { Total de } \\
\text { Vitimas }\end{array}$ & Fonte \\
\hline \multirow{2}{*}{6} & $\begin{array}{c}21 \\
\mathrm{dez} \\
2008\end{array}$ & $\begin{array}{c}\text { Ventos } \\
\text { fortes/venda } \\
\text { val; Chuvas } \\
\text { fortes }\end{array}$ & $\begin{array}{c}\text { Transbordamento de Rios } \\
\text { e Córregos, Inundações } \\
\text { Graduais, } \\
\text { Desabamentos/Rachadura/ } \\
\text { Danos em Imóveis }\end{array}$ & -1 & -1 & $\begin{array}{c}\text { Defes } \\
\text { a } \\
\text { Civil }\end{array}$ \\
\cline { 2 - 7 } & $\begin{array}{c}15 \\
\text { fev } \\
2009\end{array}$ & $\begin{array}{c}\text { Desabrigado(s); } \\
\text { Chuvas } \\
\text { fortes }\end{array}$ & $\begin{array}{c}\text { Deslizamentodo(s); } \\
\text { Desabamentos/Rachadura/ } \\
\text { Danos em Imóveis. }\end{array}$ & 97 & 72 & $\begin{array}{c}\text { Defes } \\
\text { a } \\
\text { Civil }\end{array}$ \\
\hline
\end{tabular}

Fonte: Organizado pela autora (2016).

O Boletim Climanálise aponta que, se por um lado as chuvas foram mais escassas no norte de Minas Gerais e Espírito Santo, por outro o estado de São Paulo foi favorecido com a atuação da ZCAS e com o posicionamento dos VCAN's (mais ao sul do que o mês anterior). O único episódio de ZCAS ocorreu entre os dias 12 e 16, causando chuvas fortes e impactos na sociedade. De acordo com o relatório do boletim as seis massas de ar frio que atuaram no mês não atingiram a região Sudeste, somente a região Sul do país.

Quanto à análise estatística para esse evento tem-se que, apenas a estação 02345065 apresentou valor abaixo da média, mas ainda assim, o histograma dessa estação apresenta o evento na classe de segunda maior frequência, a mesma classificação ocorreu nos histogramas das estações 02345175 e 02345017 ; já para a estação 02345067 esse evento ficou na segunda menor frequência. Essas três últimas apresentaram valores de precipitação acima da média. 
Quadro 9. Evento de impacto pluvial 7 - verão 2009/2010.

\begin{tabular}{|c|c|c|c|c|c|c|}
\hline $\begin{array}{l}\mathrm{N}^{\mathrm{o}} \text { do } \\
\text { Evento }\end{array}$ & Data & Fenômeno & Ocorrências/Danos & $\begin{array}{c}\text { Total de } \\
\text { Danos }\end{array}$ & $\begin{array}{l}\text { Total de } \\
\text { Vítimas } \\
\end{array}$ & Fonte \\
\hline \multirow{5}{*}{7} & $\begin{array}{c}08 \mathrm{dez} \\
2009\end{array}$ & $\begin{array}{c}\text { Chuvas fortes, } \\
\text { Chuvas } \\
\text { moderadas }\end{array}$ & $\begin{array}{c}\text { Desalojados. } \\
\text { Queda de Árvores, } \\
\text { Transbordamento de Rios e } \\
\text { Córregos; } \\
\text { Deslizamento de terra; } \\
\text { Desabamentos/Rachadura/D } \\
\text { anos em Imóveis; } \\
\text { Congestionamento/Interdiçã } \\
\text { o de Via Pública }\end{array}$ & 17 & -1 & $\begin{array}{c}\text { Defesa } \\
\text { Civil }\end{array}$ \\
\hline & $\begin{array}{c}09 \mathrm{dez} \\
2009\end{array}$ & $\begin{array}{l}\text { Frente } \\
\text { Fria/Chuvas } \\
\text { Contínuas; } \\
\text { Chuvas } \\
\text { Moderadas }\end{array}$ & $\begin{array}{c}\text { Desalojado(s); } \\
\text { Transbordamento de Rios e } \\
\text { Córregos; } \\
\text { Inundações Graduais; } \\
\text { Desabamentos/Rachadura/D } \\
\text { anos em Imóveis }\end{array}$ & -1 & -1 & $\begin{array}{c}\text { Defesa } \\
\text { Civil }\end{array}$ \\
\hline & $\begin{array}{c}10 \mathrm{dez} \\
2009\end{array}$ & $\begin{array}{l}\text { Frente } \\
\text { fria/chuvas } \\
\text { contínuas; } \\
\text { Chuvas } \\
\text { moderadas }\end{array}$ & $\begin{array}{c}\text { Desalojado(s); } \\
\text { Transbordamento de Rios e } \\
\text { Córregos; } \\
\text { Inundações Graduais } \\
\text { Deslizamento de terra; } \\
\text { Queda de Muro; } \\
\text { Congestionamento/Interdiçã } \\
\text { o de Via Pública; } \\
\text { Escorregamento de Encosta. }\end{array}$ & -1 & -1 & $\begin{array}{c}\text { Defesa } \\
\text { Civil }\end{array}$ \\
\hline & $\begin{array}{c}31 / 12 / \\
2009 \mathrm{e} \\
01 / 01 / \\
10\end{array}$ & $\begin{array}{l}\text { Chuvas } \\
\text { fortes,Frente } \\
\text { fria/chuvas } \\
\text { contínuas,Chuv } \\
\text { as moderadas }\end{array}$ & $\begin{array}{l}\text { Desabrigados(4000), } \\
\text { Desalojados(5000), Feridos } \\
\text { (2), Vítimas fatais(1), Queda } \\
\text { de Barreira, } \\
\text { Transbordamento de Rios e } \\
\text { Córregos, Danos em Pontes, } \\
\text { Deslizamento de terra(12), } \\
\text { Desabamentos/Rachadura/D } \\
\text { anos em Imóveis(844), } \\
\text { Corte no fornecimento de } \\
\text { energia e água, } \\
\text { Escorregamento de Encosta, } \\
\text { Rompimento da Rede de } \\
\text { Água e Esgoto. }\end{array}$ & 9859 & 9003 & $\begin{array}{l}\text { Defesa } \\
\text { Civil }\end{array}$ \\
\hline & $\begin{array}{c}03 / 01 / \\
2010\end{array}$ & Chuvas fortes & $\begin{array}{l}\text { Vítimas fatais(1), } \\
\text { Transbordamento de Rios e } \\
\text { Córregos, Danos em Pontes, } \\
\text { Deslizamento de terra, } \\
\text { Danificação em } \\
\text { Pavimentacão. }\end{array}$ & 1 & 1 & G1 \\
\hline
\end{tabular}

Fonte: Organizado pela autora (2016).

O Boletim Climanálise do mês de Dezembro de 2009 indica que a ZCAS e o escoamento de verão sobre a América do Sul foram os principais responsáveis pelo aumento de chuva nos estados do Amazonas, Acre, Minas Gerais, Rio de Janeiro e São Paulo. O aumento da 
convergência de umidade no setor central do Brasil é apontado como um efeito desencadeador dos desastres ocorridos tanto em São Luiz do Paraitinga - SP, como em Angra dos Reis - RJ. Essa convergência de umidade, por sua vez foi reforçada pela formação de um centro de baixa pressão adjacente à costa e pelo escoamento associado à Alta da Bolívia e aos vórtices ciclônicos na média e alta troposfera. O primeiro episódio de ZCAS formou-se entre os dias 03 e 04 em consequência da atuação do primeiro sistema frontal que chegava no sul do país alinhando-se com a região de convergência de umidade localizada entre as regiões CentroOeste e Sudeste. De acordo com o Boletim, entre os dias 25 e 31 uma massa de ar úmida e instável atuou em parte das regiões Centro-Oeste e Sudeste, associada a um intenso fluxo de noroeste. Concomitantemente houve uma área de baixa pressão nas proximidades dos estados de São Paulo e Rio de Janeiro, intensificando a convergência de massa adjacente à costa e que resultou no excesso de chuva.

Os valores de precipitação estiveram acima da média em todas as estações consultadas. No que diz respeito à frequênciade ocorrência do evento, ele ficou entre a primeira e segunda classe de menor ocorrência, caracterizando-se como excepcional.

Quadro 10. Evento de impacto pluvial 8 - verão 2010-2011.

\begin{tabular}{|c|c|c|c|c|c|c|}
\hline $\begin{array}{c}N^{\text {o }} \text { do } \\
\text { Evento }\end{array}$ & Data & Fenômeno & Ocorrências/Danos & $\begin{array}{c}\text { Total de } \\
\text { Danos }\end{array}$ & $\begin{array}{c}\text { Total de } \\
\text { Vitimas }\end{array}$ & Fonte \\
\hline 8 & $\begin{array}{c}19 \mathrm{dez} \\
2010\end{array}$ & $\begin{array}{c}\text { Chuvas fortes e } \\
\text { Chuvas } \\
\text { Moderadas }\end{array}$ & $\begin{array}{c}\text { Transbordamento de } \\
\text { Rios e Córregos; } \\
\text { Desabamentos/Rachadu } \\
\text { ra/Danos em Imóveis }\end{array}$ & 20 & -1 & $\begin{array}{c}\text { Defes } \\
\text { a } \\
\text { Civil }\end{array}$ \\
\cline { 2 - 7 } & 2011 & $\begin{array}{c}\text { Queda de barreira; } \\
\text { Alagamentos; } \\
\text { Desabamentos/Rachadu } \\
\text { ra/Danos em Imóveis. }\end{array}$ & 46 & -1 & $\begin{array}{c}\text { Defes } \\
\text { Civil } \\
\text { Chuvas Fortes }\end{array}$ \\
\hline
\end{tabular}

Fonte: Organizado pela autora (2016).

Para esse evento optou-se por utilizar como base os Boletins Climanálise de dezembro de 2010 e Janeiro de 2011 conjuntamente, uma vez que as ocorrências encontram-se em dias próximos. Em referência ao Boletim Climanálise de dezembro de 2010, as chuvas intensas na área estudada foram ocasionadas, principalmente pelo episódio de ZCAS. Cinco sistemas frontais atuaram no país, porém somente o quarto sistema, que ingressou no continente no dia 12 pelo estado do Rio Grande do Sul, associado ao jato em altos níveis avançou como frente fria pelo litoral paulista, onde se posicionou no dia 14, caracterizando o segundo episódio de ZCAS do mês que causou raios e rajadas de vento superiores a $100 \mathrm{~km} / \mathrm{h}$, além de precipitação na forma de granizo no interior de São Paulo e na capital. Já no Boletim de 
Janeiro de 2011 o primeiro episódio de ZCAS do mês atuou entre os dias 01 a 07, com a banda de nebulosidade associada centrada na região Sudeste, o principal sistema modulador das chuvas intensas.

Todas as estações pluviométricas apresentaram valores acima da média da série histórica para esse evento de precipitação, exceto a estação 02345067, que ficou exatamente na média. Quanto às classes de frequências tem-se que para os valores da estação 02345017 e 02345175 , esse evento ficou alocado na segunda menor frequência, enquanto que para a estação 02345065 e 02345067 ocorreram na segunda e primeira maior frequência respectivamente.

Quadro 11. Evento de impacto pluvial9 - verão 2012/2013.

\begin{tabular}{|c|c|c|c|c|c|c|}
\hline $\begin{array}{c}\mathrm{N}^{\mathbf{0}} \text { do } \\
\text { Evento }\end{array}$ & Data & Fenomeno & Ocorrencias/Danos & $\begin{array}{c}\text { Total de } \\
\text { Danos }\end{array}$ & $\begin{array}{c}\text { Total de } \\
\text { Vitimas }\end{array}$ & Fonte \\
\hline 9 & $\begin{array}{c}11 \text { jan } \\
2013\end{array}$ & $\begin{array}{c}\text { Chuvas } \\
\text { moderadas }\end{array}$ & $\begin{array}{c}\text { Desalojado(s); } \\
\text { Transbordamento de } \\
\text { Rios e Córregos; } \\
\text { Inundações Graduais }\end{array}$ & 26 & 26 & $\begin{array}{c}\text { Defesa } \\
\text { Civil }\end{array}$ \\
\hline
\end{tabular}

Fonte: Organizado pela autora (2016).

De acordo com a descrição do Boletim Climanálise de janeiro de 2013 sobre os sistemas atmosféricos atuantes, houve o primeiro episódio de ZCAS desse mês quando a ocorrência descrita acima foi registrada. Esse episódio atuou entre os dias 09 e 14 especialmente sobre os estados de São Paulo, Minas Gerais, Rio de Janeiro e leste do Mato Grosso, onde foram registrados os maiores valores acumulados de precipitação. Quanto aos Vórtices Ciclônicos que se configuraram no escoamento em $200 \mathrm{hPa}$ sobre o oceano Atlântico, destaca-se o terceiro e o quinto, por contribuírem para a manutenção dos episódios de ZCAS.

Todas as estações analisadas classificaram esse evento como acima da média para os valores de precipitação dentro da série histórica e dentro da primeira e segunda classe de maior ocorrência. 


\subsubsection{Climatologia de precipitação}

Estação 02345017

Total Acumulado (mm)

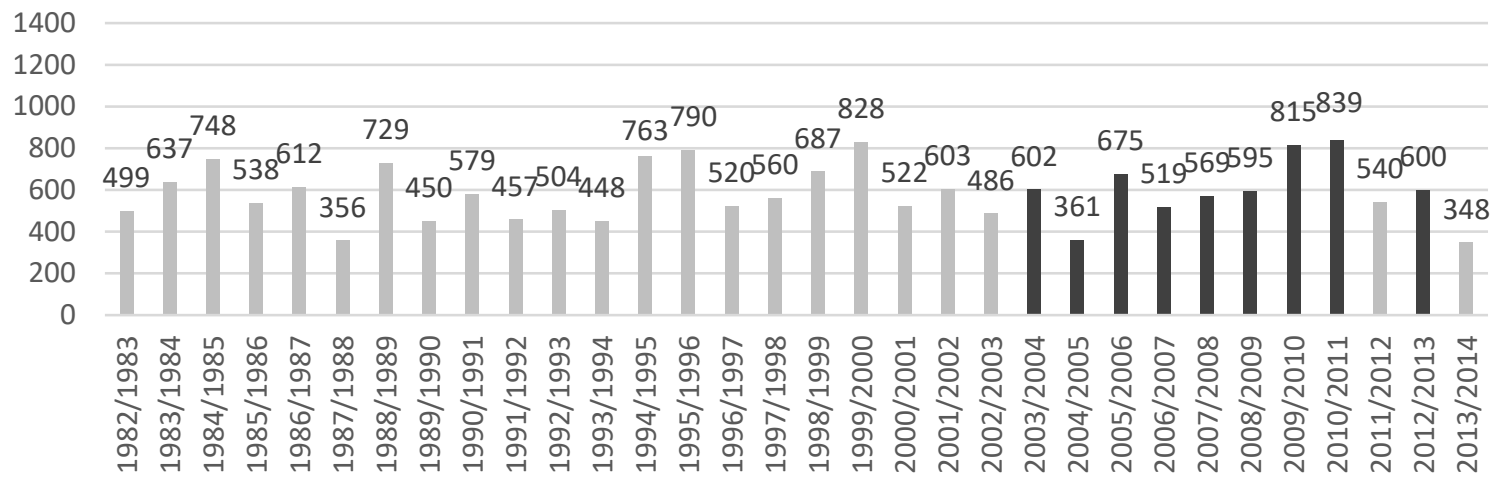

Desvio da média (mm)

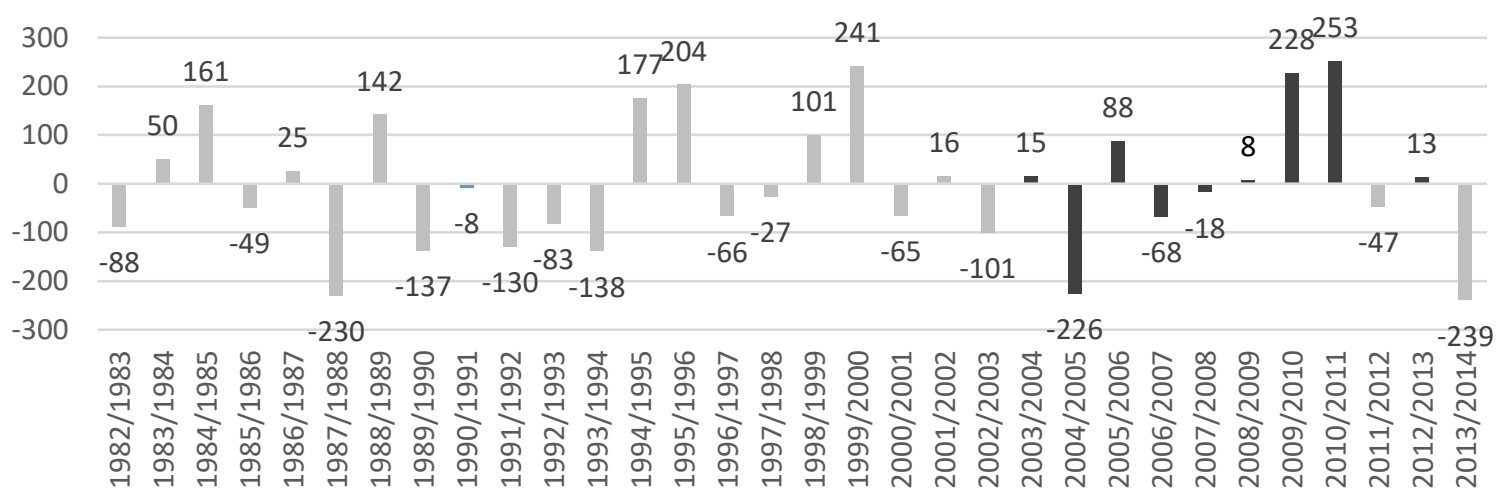

\section{Histograma}

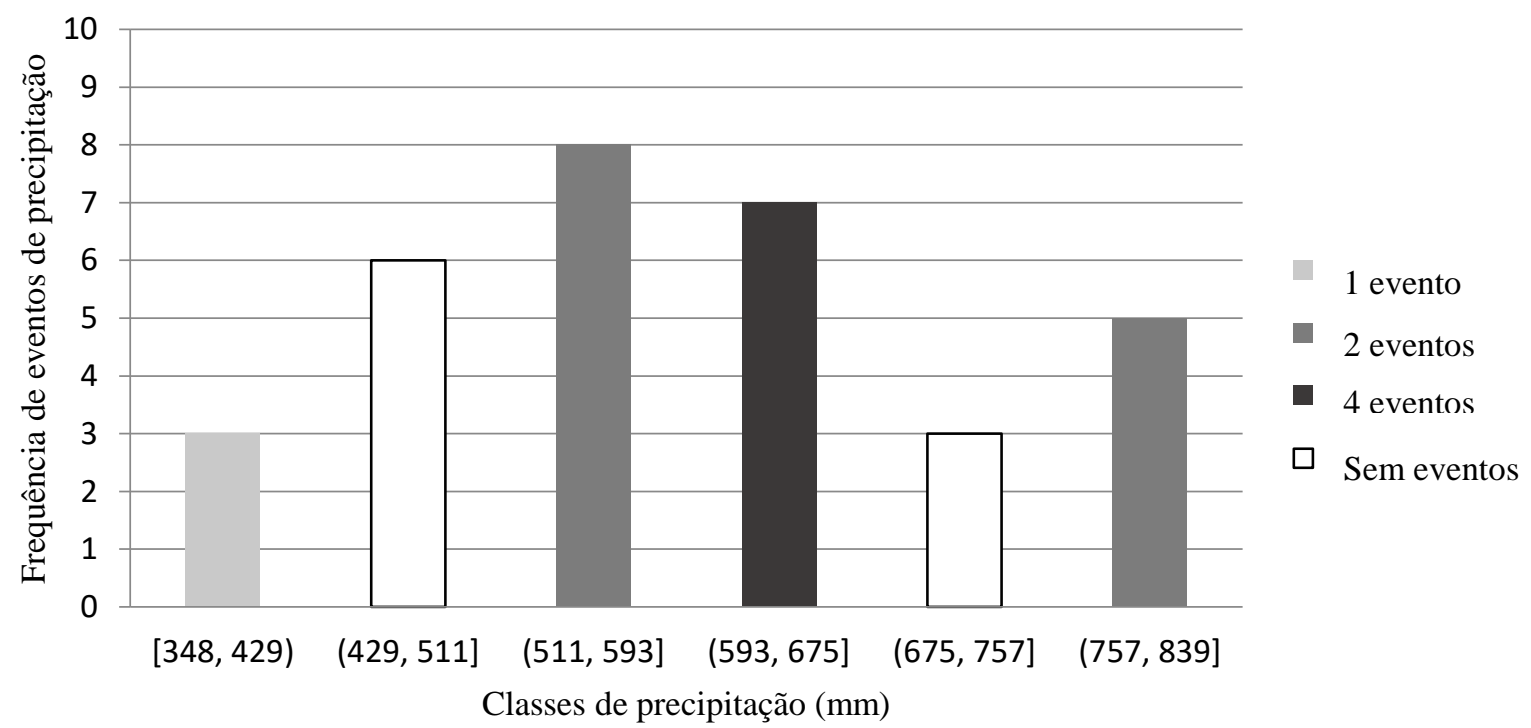




\section{Estação 02345065}

Total acumulado (mm)

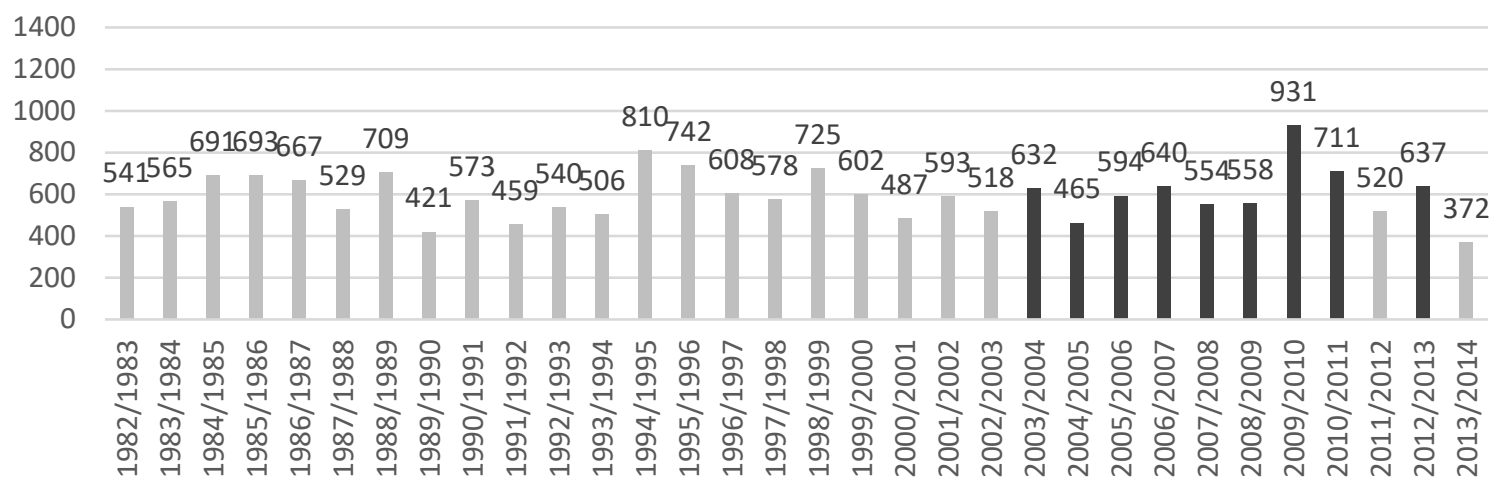

Desvio da média (mm)

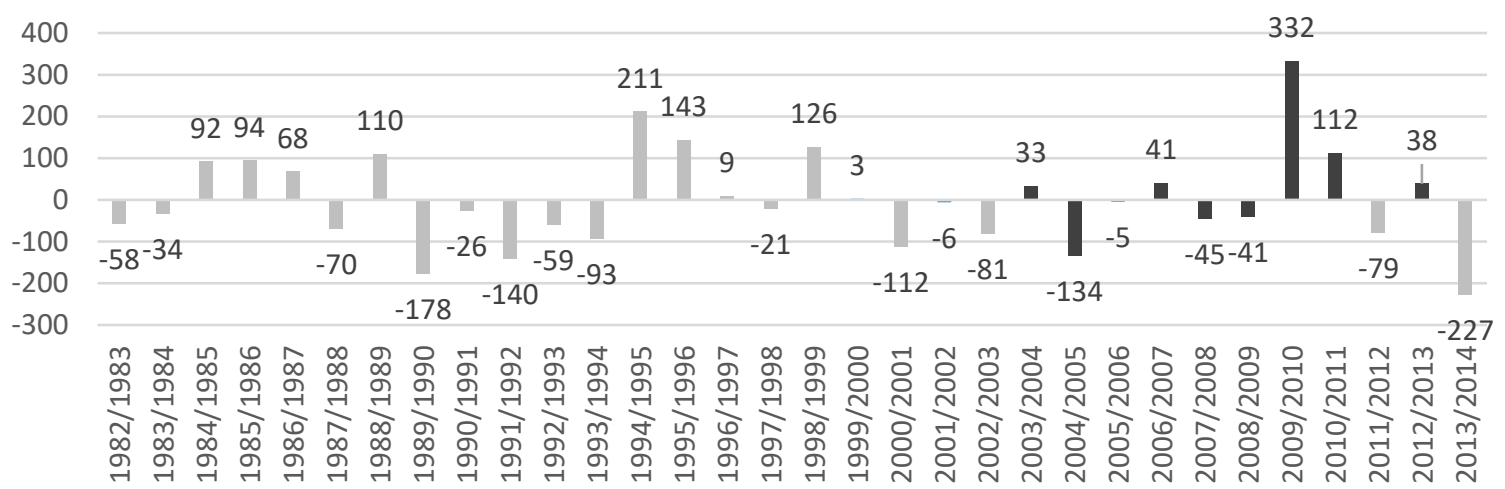

Histograma

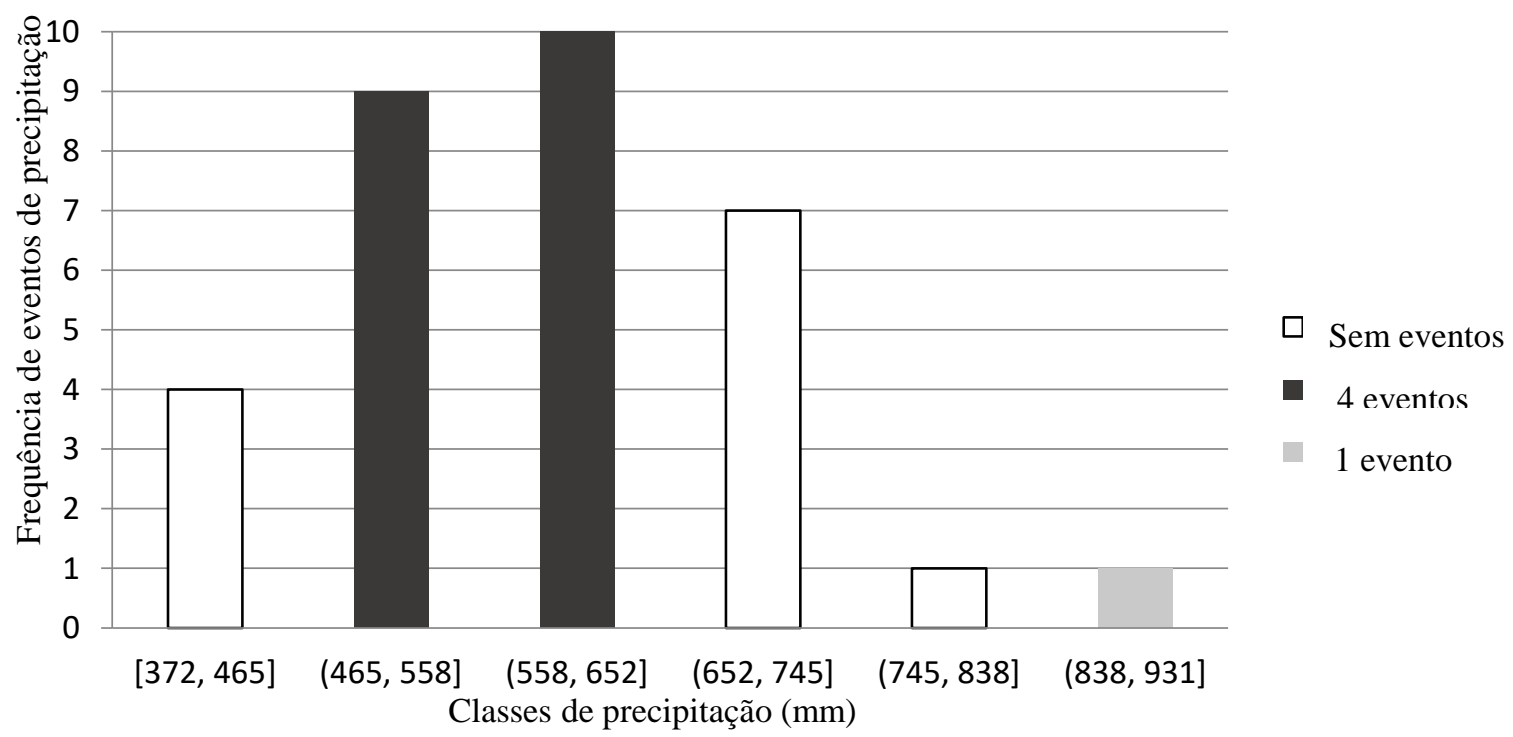




\section{Estação 02345067}

Total Acumulado (mm)

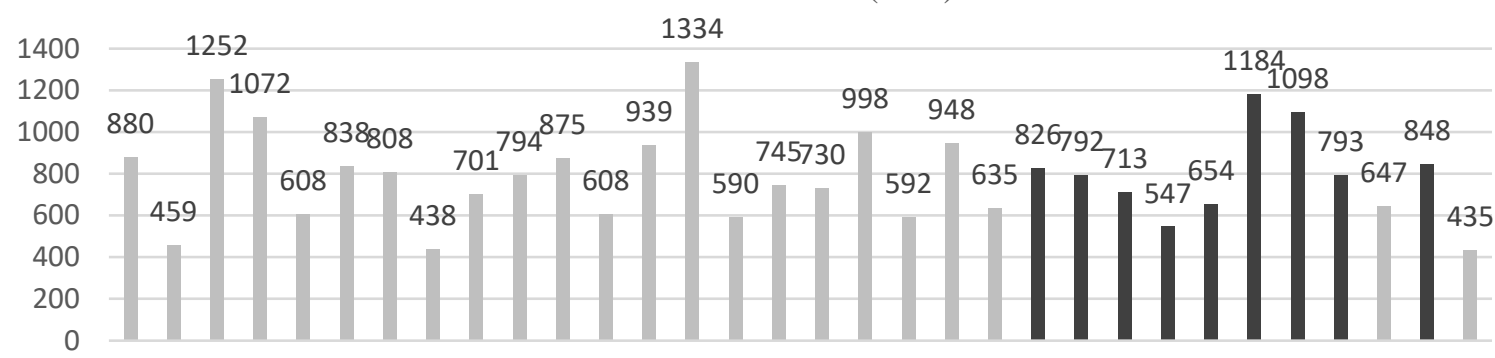

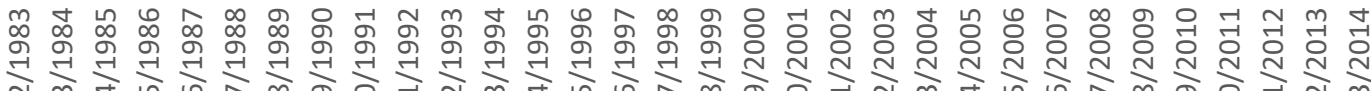
心

Desvio da média ( $\mathrm{mm})$

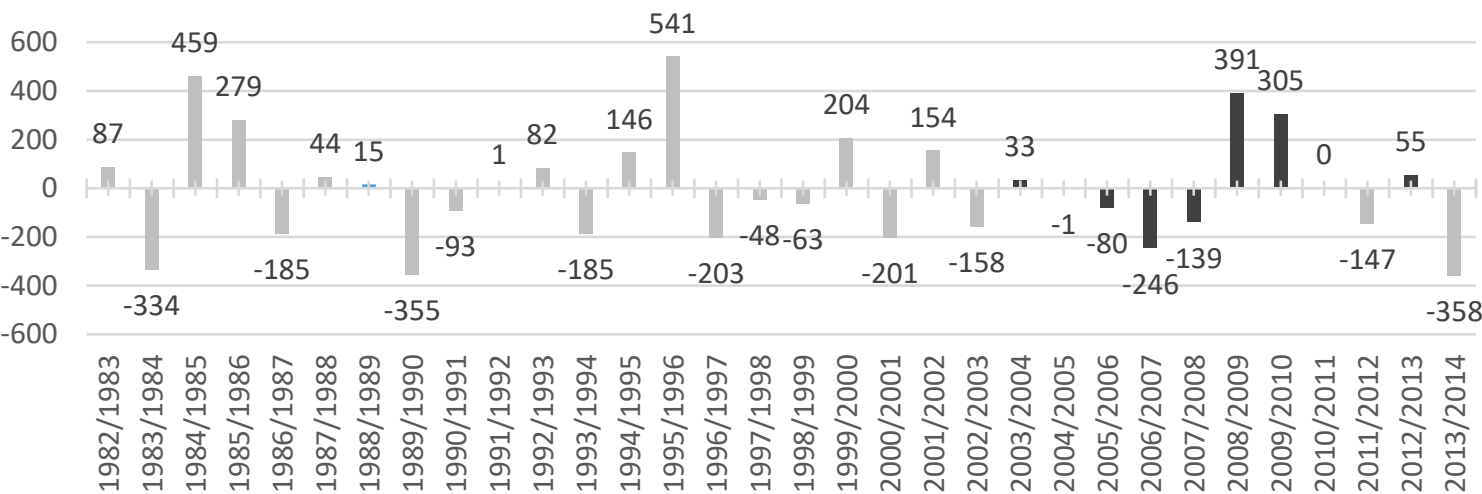

\section{Histograma}

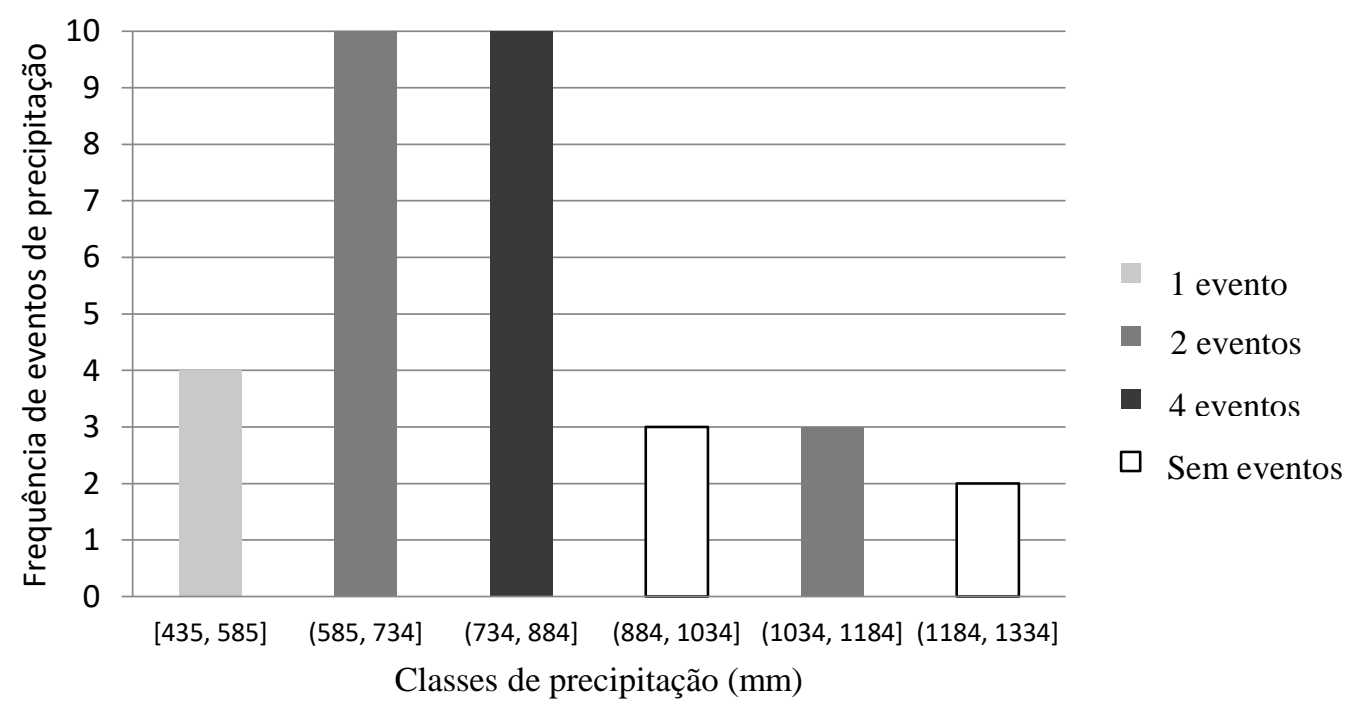




\section{Estação 02345175}

Total Acumulado (mm)

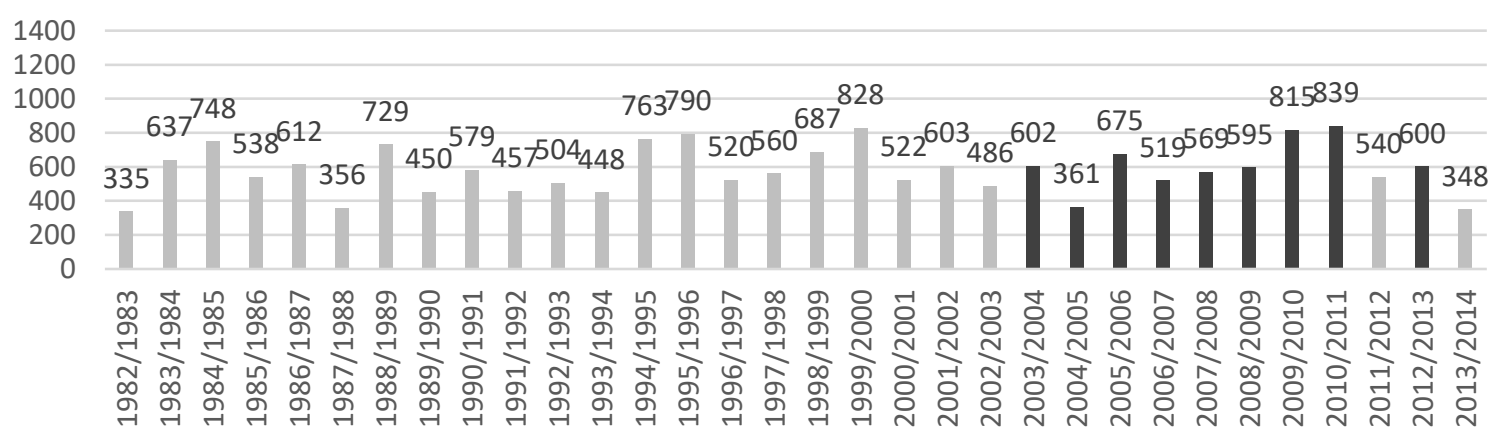

Desvio da média (mm)

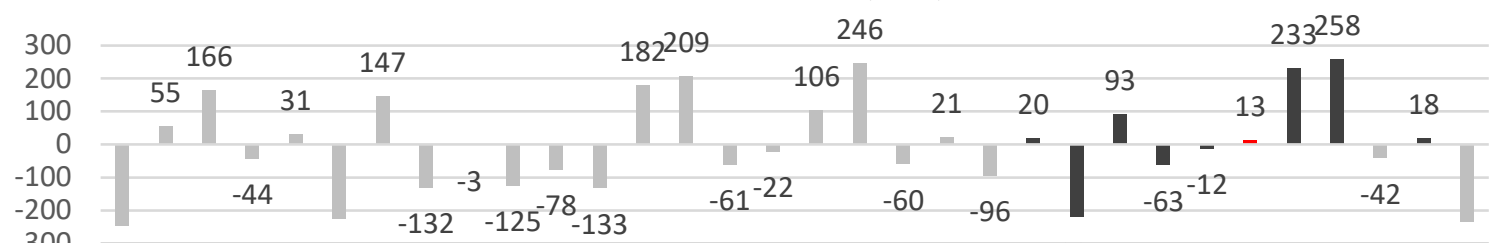

$-300$

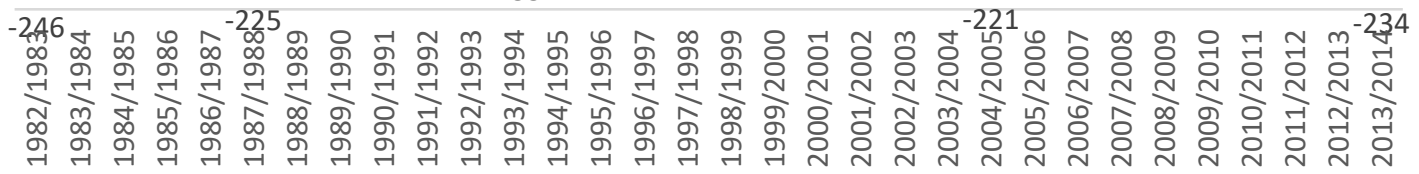

\section{Histograma}

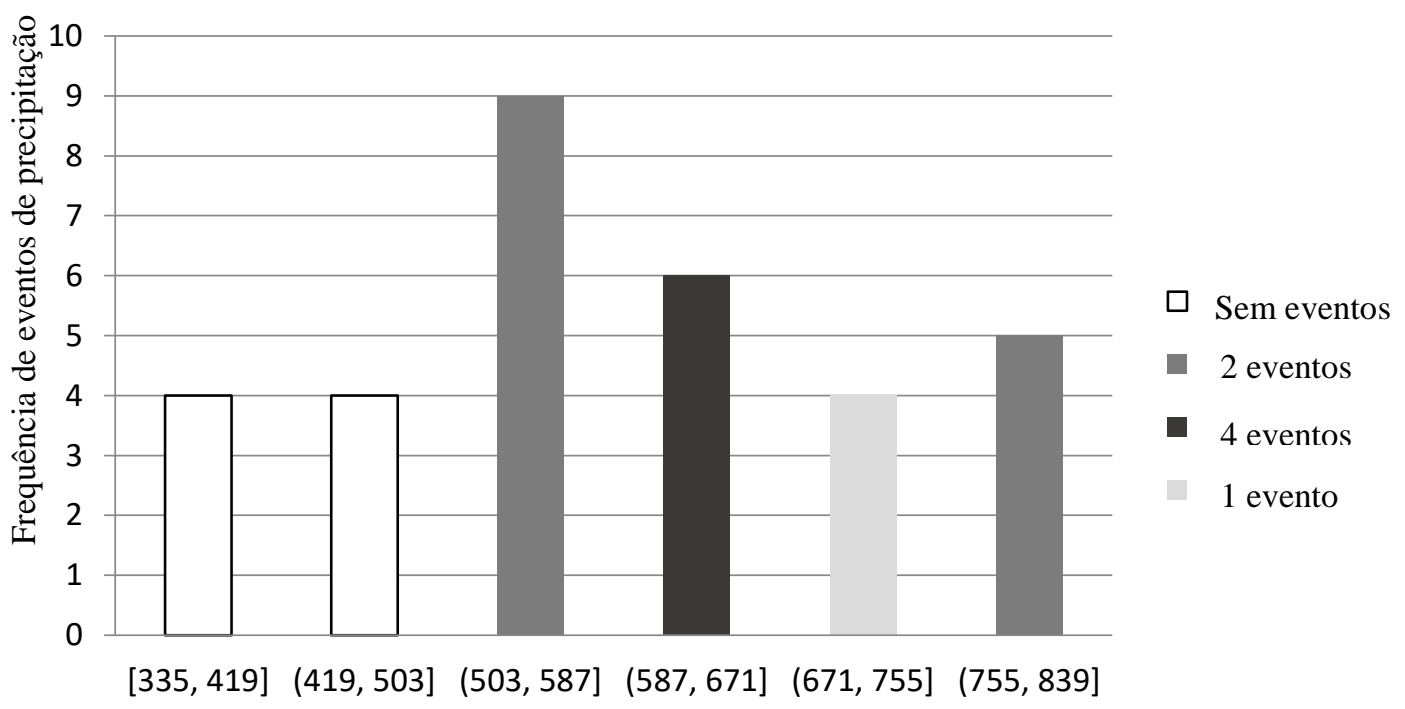

Classes de precipitação (mm) 
Tabela 5. Tipo e frequência de danos na série de impactos analisada.

\begin{tabular}{|l|c|}
\hline \multicolumn{1}{|c|}{ Danos } & $\begin{array}{c}\text { Número de ocorrências nos dias } \\
\text { analisados }\end{array}$ \\
\hline Ferido(s) & 1 \\
\hline Queda de Árvores & 1 \\
\hline Corte no fornecimento de energia e água & 1 \\
\hline Danificação em Pavimentação & 1 \\
\hline Rompimento da Rede de Água e Esgoto & 2 \\
\hline Vítima(s) fatal(is) & 2 \\
\hline Queda de Barreira & 2 \\
\hline Danos em Pontes & 2 \\
\hline Alagamentos & 2 \\
\hline Queda de Muro & 3 \\
\hline Desabrigado(s) & 3 \\
\hline Escorregamento de Encosta & 4 \\
\hline Congestionamento/Interdição de Via Pública & 6 \\
\hline Inundações Graduais & 8 \\
\hline Deslizamento de terra & 9 \\
\hline Desalojado(s) & 10 \\
\hline Transbordamento de Rios e Córregos & 11 \\
\hline Desabamentos/Rachadura/Danos em Imóveis & \\
\hline
\end{tabular}

Fonte: Organizado pela autora (2016).

\section{CONSIDERAÇÕES FINAIS}

As discussões sobre desastres naturais e seus impactos têm avançado tanto na academia, quanto no setor público administrativo e também no setor privado. Grande ganho para o avanço dessa temática é o entendimento de que os impactos não estão relacionados somente com o evento atmosférico em si, mas também com as atividades antrópicas que modificam o ambiente das quais o local está sendo, historicamente, submetido.

A análise aplicada ao município de São Luiz do Paraitinga - SP evidenciou que o município sofre com os impactos pluviais há quase uma década e, destaca-se aqui que, na pesquisa, foram utilizados apenas os impactos registrados pela defesa civil e disponíveis no Banco de 
Dados de Desastres Naturais do IPMet, ou seja o município pode ter sofrido muitos outros impactos mas que não foram registrados no Banco de Dados.

Analisando-se a estatística descritiva dos valores de precipitação na série de impactos pôde-se observar que a maioria dos eventos ocorreu sob precipitação acima da média, porém com valores considerados recorrentes para o recorte temporal analisado (DEZ/JAN/FEV).

Ainda sobre os dados de precipitação vale destacar aqui a necessidade de realizar a manutenção e revisão das estações coletoras dos dados. Para a presente pesquisa, por exemplo, entre as 12 estações localizadas dentro do município de São Luiz do Paraitinga, apenas 4 delas apresentavam quantidade aceitável de dados para uso na pesquisa (32 últimos verões).

Na perspectiva do mecanismo produtor de chuvas, tem-se a predominância da atuação da ZCAS ocasionando chuvas fortes, sua atuação costuma se iniciar em outubro e perdura até março. Em decorrência da importância desse mecanismo atmosférico para a gestão e diminuição dos riscos e desastres é de suma importância a compreensão de sua atuação e aprimoramento de sua previsibilidade.

A consulta ao Banco de Desastres Naturais do IPMet permitiu a compreensão e a quantificação dos danos ocasionados, dessa maneira tem-se que os danos estruturais na cidade apareceram com maior frequiência na iminência do impacto, como por exemplo, o Transbordamento de Rios e Córregos (10 vezes) e Desabamentos/Rachadura/Danos em Imóveis (11 vezes).

No entanto, para que se disponibilize uma amostra maior de eventos de impacto na área estudada faz-se necessário a alimentação contínua do Banco de Dados. Outro ponto importante seria vincular o banco de dados a uma plataforma que calculasse as medidas estatísticas das variáveis climáticas. Tal nível de detalhamento auxiliaria nas ações de prevenção de possíveis impactos e na mitigação daqueles já ocorridos.

Os resultados da pesquisa de uma forma geral mostraram que a partir da análise de impactos pluviais é possível identificar os pontos mais vulneráveis a danos deflagrados pela chuva e então, disponibilizar informações e conhecimento que sirvam de base para a execução de ações que visem o desenvolvimento de municípios mais resilientes a esses eventos atmosféricos. 
Como sugestão para trabalhos futuros, seria importante detalhar numa escala diária os trimestres referentes aos eventos de impactos. Isso porque a escala diária permite mostrar possíveis eventos de chuva extrema e breves. Dados que, quando colocados numa escala trimestral, são mascarados.

\section{REFERÊNCIAS}

AGÊNCIA DA BACIA DO RIO PARAÍBA DO SUL. Comitê do médio Paraíba do Sul. Disponível em:<http://www.cbhmedioparaiba.org.br/regiaohidro.php>. Acesso em: 6 nov. 2015.

AGÊNCIA NACIONAL DE ÁGUAS. Bases de dados georreferenciadas. Rede hidrográfica codificada. Disponível

em:<http://www.ana.gov.br/bibliotecavirtual/solicitacaoBaseDados.asp>. Acesso em: 2 mar. 2016.

Inventário das estações pluviométricas.2.ed.Brasília: ANA; SGH, 2009.

AGÊNCIA NACIONAL DE ÁGUAS. Deliberações CEIVAP. Mapa da bacia. Disponível em:<http://arquivos.ana.gov.br/institucional/sag/CobrancaUso/BaciaPBS/_img/MapaPBS.jpg >. Acesso em: 17 nov. 2015.

AMARAL, R.; GUTJAHR, M.R.Desastres naturais.São Paulo: IG/SMA, 2011.(Série Cadernos de Educação Ambiental, 8).

AMBRIZZI, T.Climatologia 1. São Paulo: IAG/USP; Departamento de Ciências Atmosféricas, 2014.

ANDRÉ, I.R.N.et al. Clima, variabilidade, mudanças climáticas e uma proposta metodológica para mapeamento de danos provenientes de eventos severos.Geografia, v.34, p.595-606, 2009.

ATLAS brasileiro de desastres naturais: 1991 a 2012. 2.ed.rev.ampl. Florianópolis:UFSC/CEPED, 2013.

AYOADE, J.O.Introduçao à climatologia para os trópicos.Tradução de Maria Juraci Zani dos Santos; revisão de Suely Bastos; coordenação editorial de AntonioChristofoletti.14.ed.Rio de Janeiro: Bertrand Brasil, 2010.

BOIN, M.N.; ZAVATTINI, J.A.Climatologia geográfica - teoria e prática de pesquisa.Campinas: Alínea, 2013.

BORSATO, V. A. A Climatologia dinâmica e o ensino da geografia no segundo grau: uma aproximação ao problema. Revista GeoNotas, v.4, n.1, 2000.

BRAIDO, L.M.H.; TOMMASELLI, J.T.G. Caracterização climática e dos anos extemos (chuvoso e seco): seus efeitos na produção de cana-de-açúcar, milho e soja para a região do pontal do Paranapanema - SP. Revista Formação, v.1, n.17, p. 13-34, 2010. 
BRASIL.Lei 12.608, de 10 de abril de 2012. Institui a Política Nacional de Proteção e Defesa Civil - PNPDEC; dispõe sobre o Sistema Nacional de Proteção e Defesa Civil -SINPDEC e o Conselho Nacional de Proteção e Defesa Civil - CONPDEC; autoriza a criação de sistema de informações e monitoramento de desastres; altera as Leis nos 12.340, de 1o de dezembro de 2010, 10.257, de 10 de julho de 2001, 6.766, de 19 de dezembro de 1979, 8.239, de 4 de outubro de 1991, e 9.394, de 20 de dezembro de 1996; e dá outras providências. Diário Oficial da União, Brasília, DF, 11 abr. 2012, Seção 1, p.1.

BRASIL. Ministério da Integração Nacional. Sistema Integrado de Informações sobre Desastres. Disponível em: <https://s2id.mi.gov.br/>. Acesso em: 8 mar. 2017.

BUSCH, S. Quantifying the risk of heavy rain: its contribution to damage in urban areas. In: INTERNATIONAL CONFERENCE ON URBAN DRAINAGE, 11., Edinburgh, 2008. Proceedings... International Conference Centre, 2018.

CASCO, S.L. et al. Inundacion en el Bajo Paraná ¿Se puede articular La gestión social a partir delcomportamiento hidrológico previo? Interciencia [enlinea], v.36, Junio, 2011. Disponivel em: $<$ http://www.redalyc.org/articulo.oa?id=33919418005>. Acesso em: 10 maio 2016.

COELHO, F.C. Computação científica com python: uma introdução à programação para cientistas. Petrópolis: Edição do Autor, 2007.

COLABONE, R.O. Nevoeiro e dinâmica atmosférica: uma contribuição ao estudo sobre ocorrências de nevoeiro no aeródromo da Academia da Força Aérea -

Pirassununga/SP.2011.Tese (Doutorado em Ciências da Engenharia Ambiental) - Escola de Engenharia de São Carlos, Universidade de São Paulo, São Carlos, 2011.Disponível em: <http://www.teses.usp.br/teses/disponiveis/18/18139/tde-19122011-143601/>.Acessoem: 1 nov.2015.

THE COMET PROGRAM.University Corporation for Atmospheric Research.Space and time-scales os dynamical atmospheric process.2016. Disponível em:<https://www.meted.ucar.edu/search/details.php?id=24961>. Acesso em: 7Apr. 2017.

COMO CONSTRUIR cidades mais resilientes: um guia para gestores públicos locais: uma contribuição à campanha global 2010-2015 construindo cidades resilientes - minha cidade está se preparando! Genebra, Nações Unidas, 2012. Cap.2, p.55-56. Disponível em:〈http://www.unisdr.org/files/26462_guiagestorespublicosweb.pdf $>$. Acesso em: 4 maio 2016.

CORSI, A.C.; AZEVEDO, P.B.M.; GRAMANI, M.F.Valoração de danos decorrente da inundação em São Luiz do Paraitinga.Revista de Gestão Ambiental e Sustentabilidade [enlinea], v.1, n.2, 2012. Disponível em:<http://www.redalyc.org/articulo.oa?id=471647097006>. Acesso em: 15 maio 2017.

CUNHA, D.G.F.; VECCHIA, F.As Abordagens clássica e dinâmica de clima: uma revisão bibliográfica aplicada ao tema da compreensão da realidade climática.Ciência e Natura, v.29, p.137-149, 2007. 
DIRETORIA DE HIDROGRAFIA E NAVEGAÇÃO. Centro de Hidrografia da Marinha. Serviço Meteorológico Marinho.Cartassinóticas.Disponível em: $<$ https://www.mar.mil.br/dhn/chm/meteo/prev/cartas/cartas.htm>. Acessoem: 10 out. 2015 .

DOWNEY, A.Thinkp python: how to think like a computer scientist.Needham: Green Tea, 2012.

EM-DAT.The International Disaster Database.Centre for Research on the Epidemiology of Disasters.Disponível em:<http://www.emdat.be/>. Acesso em: 8 Mar. 2017.

FELÍCIO, R.A.ClimatologiaII.Disponível

em: <http://www.fakeclimate.com/arquivos/Apoio/CartasSinopticas.pdf $>$. Acesso em: 10 out. 2015.

Climatologia dinâmica da antártida: ciclones extratropicais que atuaram nos verões e invernos de 2001 a 2006 na região da Península Antártica.2007.Tese (Doutorado em Geografia) - Faculdade de Filosofia, Letras e Ciências Humanas, Universidade de São Paulo, São Paulo, 2007.

FLICKR. Visita à São Luiz do Paraitinga, 2014. Disponível em <https://www.flickr.com/photos/governosp/albums/72157644332851550/with/14035642659/> Acesso em 24 mai 2016.

FORBELLONE, A.L.V.Lógica de programação: a construção de algoritmos e estruturas de dados. 3.ed. São Paulo: Prentice Hall, 2005.

FURTADO, J. et al. Capacitação básica em defesa civil . 3.ed. Florianópolis: UFSC/CEPED, 2013.

GMAPAS. Polígonos dos municípios de São Paulo. Disponível em:<http://www.gmapas.com/poligonos-ibge/poligonos-municipios-ibge-sao-paulo>. Acesso em: 14 jun. 2016.

HIDROWEB: sistemas de informações hidrológicas. Séries históricas. Disponível em: $<$ http://hidroweb.ana.gov.br/HidroWeb.asp?TocItem=1080\&TipoReg=7\&MostraCon=true \& CriaArq=false $\&$ TipoArq=0\&SerieHist=true $>$. Acesso em: 15 out. 2015.

INSTITUTO BRASILEIRO DE GEOGRAFIA E ESTATÍSTICA. Malha dos setores censitários 2010. Disponível em:<ftp://geoftp.ibge.gov.br/recortes_para_fins_estatisticos/malha_de_setores_censitarios/ce nso_2010/base_de_faces_de_logradouros>. Acesso em: 14 set. 2016.

INSTITUTO FlORESTAL. Plano de manejo do Parque Estadual da Serra do Mar. Disponível em:<http://fflorestal.sp.gov.br/planos-de-manejo/planos-de-manejo-planosconcluidos/>. Acessado em: 23 jan. 2017.

INSTITUTO NACIONAL DE METEOROLOGIA.Monitoramento das estações automáticas.Disponível em:<http://www.inmet.gov.br/sonabra/maps/pg_automaticas.php>. Acesso em: 13 out. 2015. 
Rede de Estações. Disponível em <http://www.inmet.gov.br/html/rede_obs.php> Acesso em 13 out 2015.

INSTITUTO NACIONAL DE PESQUISAS ESPACIAIS. Centro de Previsão de tempo e Estudos Climáticos. Análise sinótica. Disponível

em: $<$ http://www.cptec.inpe.br/noticias/faces/noticias.jsp?idConsulta=\&idQuadros=142>. Acesso em: 10 out. 2015.

Centro de Previsão de tempo e Estudos Climáticos. Evolução mensal e sazonal das chuvas. Disponível em: $<$ http://clima1.cptec.inpe.br/evolucao/pt $>$. Acessoem: 8 abr. 2017.

LIN, J.W.B. A Hands-on introduction to using python in the atmospheric and oceanic sciences. San Francisco, CA, 2012. Disponível em:<http://www.johnny-lin.com/pyintro >. Acesso em: 07mar 2016.

MARCELINO, E.V.Desastres naturais e geotecnologias: conceitos básicos.São José dos Campos: INPE, 2008.

MARCHEZINI, V. et al. Desenvolvimento, desastres e reconstrução: o caso de São Luiz do Paraitinga/SP, Brasil.Revista Brasileira de Gestão e Desenvolvimento Regional, v.3, n.2, p.202-226, maio/ago. 2017.

MARTINELLI, M.Clima do Estado de São Paulo. Confins: revista franco-brasileira de geografia(Online), v.8, n.8, 2010. Disponível em: $\langle$ https://confins.revues.org/?lang=pt $>$. Acesso em:05 jun 2016

MATHER, J.R. Climatology: fundamentals and applications. New Yor: McGraw-Hill Book, 1974.

MATTEDI, M.A.; BUTZKE, I.C.A Relação entre o social e o natural nas abordagens de hazards e de desastres.Ambiente\& Sociedade, ano4, n.9, 2 sem.,2001. Disponível em<http://www.scielo.br/pdf/asoc/n9/16877.pdf >. Acesso em:04 abr 2017.

MELLO, R.Y.; KOHLS, W.; OLIVEIRA, T. M. N., Uso de diferentes métodos para o preenchimento de falhas em estações pluviométricas. Bol. geogr., Maringá, v. 35, n. 1, p. 112-121, 2017. DOI: http://dx.doi.org/10.4025/bolgeogr.v35i1.30893.

MENDES, J.M. et al. Risco, vulnerabilidade social e estratégias de planeamento - uma abordagem integrada. Coimbra: Universidade de Coimbra, Centros de Estudos Sociais, 2011. (Relatório FCOMP-01-0124-FEDER-007558).

MODENESI-GAUTTIERI, M.C. et al.A Obra de Aziz NacibAb'Sáber. São Paulo: BecaBALL, 2010.

MONTEIRO, C.A.F.Dinâmica climática e as chuvas no Estado de São Paulo: estudo geográfico sob forma de atlas. São Paulo: Universidade de São Paulo/Instituto de Geografia, 1973. 
. Clima e excepcionalismo - conjecturas sobre o desempenho da atmosfera como fenômeno geográfico. Florianópolis: Ed.UFSC, 1991.

MOURA, C.A.; JIMENEZ-RUEDA, J.R.; MARTINS COELHO, J.O. O Processo pedogenético no domínio tropical atlântico - o exemplo do Vale do Paraíba do Sul/SP.In: SIMPÓSIO NACIONAL DE GEOMORFOLOGIA / REGIONAL CONFERENCE ON GEOMORPHOLOGY, 4.,Goiânia, 2006. Anais...Meghalaya: International Association of Geomorphologists, 2006.

NUNES, L.H.Compreensões e ações frente aos padrões espaciais e temporais de riscos e desastres.Territorium, v.16, n.1, p.181-189, 2009.

PELLEGRINA,G.J. Proposta de um procedimento metodológico para o estudo de problemas geoambientais com base em banco dedados de eventos atmosféricos severos. 2011. Dissertação (Mestrado)-Faculdade de Engenharia, Universidade Estadual Paulista Bauru, 2011.

PLANO DIRETOR PARTICIPATIVO DO MUNÍCIPIO DA ESTÂNCIA TURÍSTICA DE SÃO LUIS DO PARAITINGA. Mapa do Macrozoneamento Urbano. FUNDUNESP. Disponível em <http://www.saoluizdoparaitinga.sp.gov.br/site/wpcontent/uploads/plano_diretor/SAO\%20LUIS\%20-\%20MACROZONEMENTO\%20\%202011.pdf> Acesso em 01 jun 2016.

QUADRO, M.F.L.: PEZZI, L.P.; ROSA, E.B.O Climanálise e o monitoramento da ZCAS nos últimos 30 anos.RevistaClimanálise, ano 3, n.1, 2006. Disponível em: <http://climanalise.cptec.inpe.br/ rclimanl/revista/pdf/30anos/quadroetal.pdf $>$. Acesso em: 6 jun. 2017.

REPORTER BRASIL.Eucalipto avança em São Luiz do Paraitinga e gera reações. Disponível em:<http://reporterbrasil.org.br/2009/07/eucalipto-avanca-em-sao-luiz-doparaitinga-e-gera-reacoes/>. Acesso em: 19 abr. 2016.

RUIZ, L.L.São Luiz do Paraitinga sofre com as chuvas do início de ano.Foto.Disponível em: <http://vejasp.abril.com.br/materia/sao-luiz-do-paraitinga-sofre-com-as-chuvas-do-iniciode-ano/>. Acesso em: 2 out. 2015.

SANTOS, C.M.P.Desorganizando e reorganizando o território: o turismo e o desenvolvimento local em São Luiz do Paraitinga/SP.Revista Eletrônica de Turismo Cultural. 2007. Disponível em: $<$ http://www.eca.usp.br/turismocultural/carlos.pdf $>$. Acesso em: 20 jul. 2017.

SANTOS, M.A Urbanização brasileira. 5.ed.São Paulo: EDUSP, 2005.

SÃO PAULO (Estado). Coordenadoria de Planejamento Ambiental. Secretaria do Meio Ambiente. Mapa de uso e cobertura da terra UGRHI 5 PCJ. Disponível em:<http://www.ambiente.sp.gov.br/cpla/mapa-de-uso-e-ocupacao-da-terra-ugrhi-5-pcj/ >. Acesso em: 27 set. 2015.

SCHIAVETTI, A.; CAMARGO, M.F.A.Conceitos de bacias hidrográficas - teorias e aplicações. Ilhéus: Ed.UESC, 2002. 
SORIANO, E. et al. Identificação e análise da comunicação dorisco de desastres naturais em municípios do estado de São Saulo (Brasil).Revista da ANPEGE, v.12, n.19, p.390-408, jul./dez. 2016.

THOMPSON, R.; PERRY, A.Appliedclimatology: principlesandpractice.New York: Routledge, 1997.

TUCCI, E.M.C.Hidrologia:ciência e aplicação. Porto Alegre: Ed.UFRGS; ABRH, 2002. Avaliação ambiental integrada de bacia hidrográfica. Brasília: MMA,2006.

UNIVERSIDADE ESTADUAL PAULISTA “JULIO DE MESQUITA FILHO”. IPMet Faculdade de Ciências. Banco de dados de desastres naturais. 2016. Disponível em: $\langle$ http://www.ipmet.unesp.br/index2.php?menu_esq1=\&abre=ipmet_html/defesa_civil/index.php $>$. Acesso em:30 mar 2015.

VALENCIO, N.F.L.S. etal.Implicações éticas e sociopolíticas das práticas de Defesa Civil diante das chuvas: reflexões sobre grupos vulneráveis e cidadania participativa.São Paulo em Perspectiva, v.20, n.1, p.96-108, jan./mar. 2006. 


\section{APÊNDICE 1}

$\underline{\text { Rotina em python para estatística descritiva }}$

\#Script para análise estatística

\#Pandas para ler a planilha

\#Numpy para Estatística

\#Matplotlib para plotar os gráficos

importpandasaspd

importnumpyasnp

importmatplotlib.pyplot as plt

\#importa os dados de uma planilha excel

dados

pd.read_excel(r'C:IUsers\IsabelalDropbox\PESQUISAIDADOS_SCRIPT\TESTE_SCRIPT.x1

sx')

dados.columns $=$ ['Estacao', 'Verao', 'Data', 'Total']

\#deleta uma coluna

del dados['Estacao']

\#calcula o Total acumulado por Verao

dados2=dados.groupby('Verao').sum()

dados2.columns $=[$ 'Total' $]$

\#plota a coluna "Total"

dados2.Total.plot()

\#calcula a media do Total acumulado dos verões

media $=$ np.mean $($ dados $2 \cdot$ Total $)$

dados2['Media']=media

\#plota Media

dados2.Media.plot()

\#calcula o desvio da media

dados2['Desvio']=dados2.Total-dados2.Media

\#plota o Desvio

dados2.Desvio.plot()

\#calcula e plota o histograma

res $=$ plt.hist $\left(\right.$ dados 2. Total,bins $=6$,range $\left.=\left[X_{\min }, X_{\max }\right]\right)$

\#Salva o arquivo em csv

dados2.to_csv(r"C:IUsers\IsabelalDropbox \PESQUISAIDADOS_SCRIPT\dados2.txt", ";") 
APÊNDICE 2

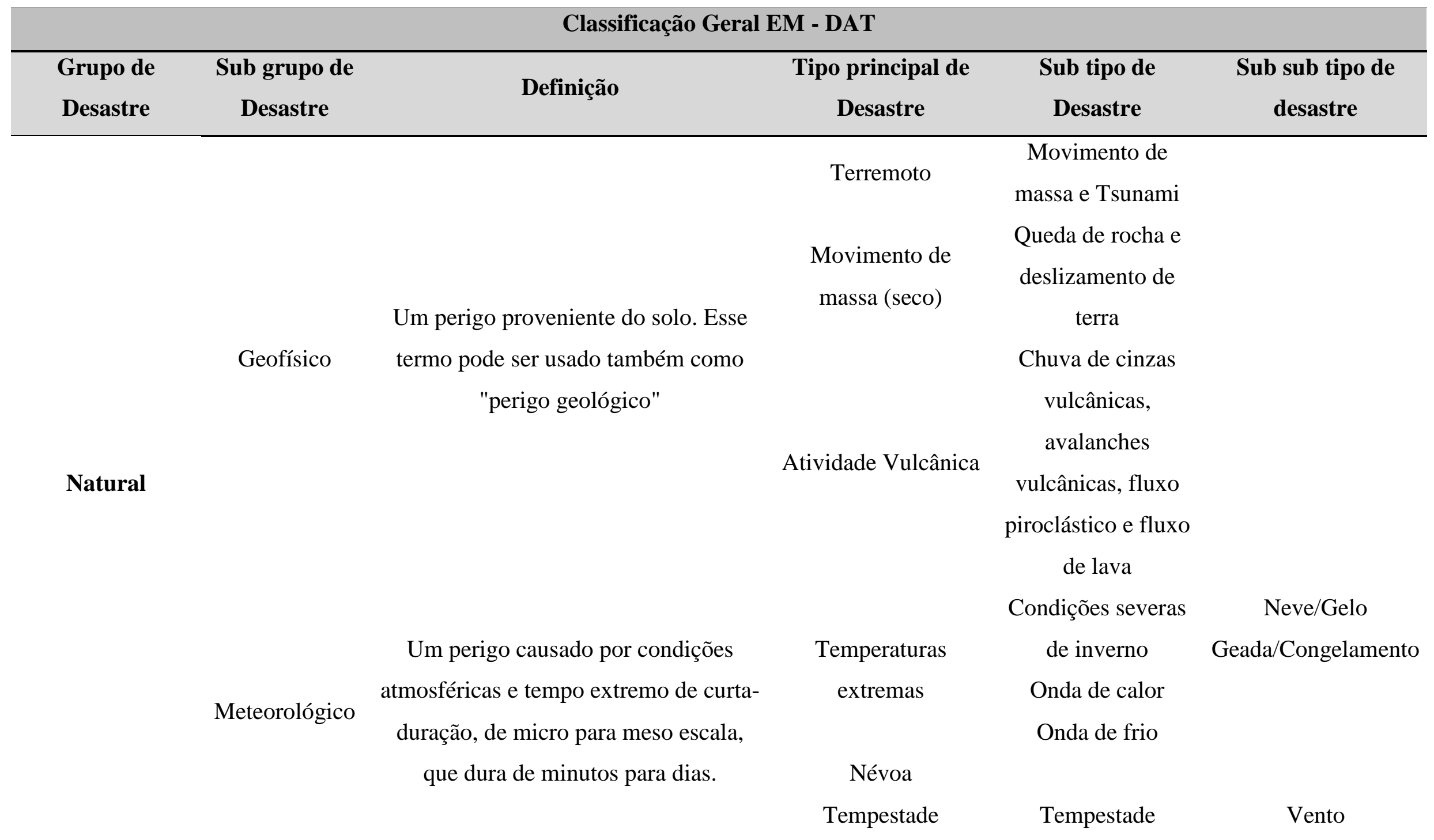




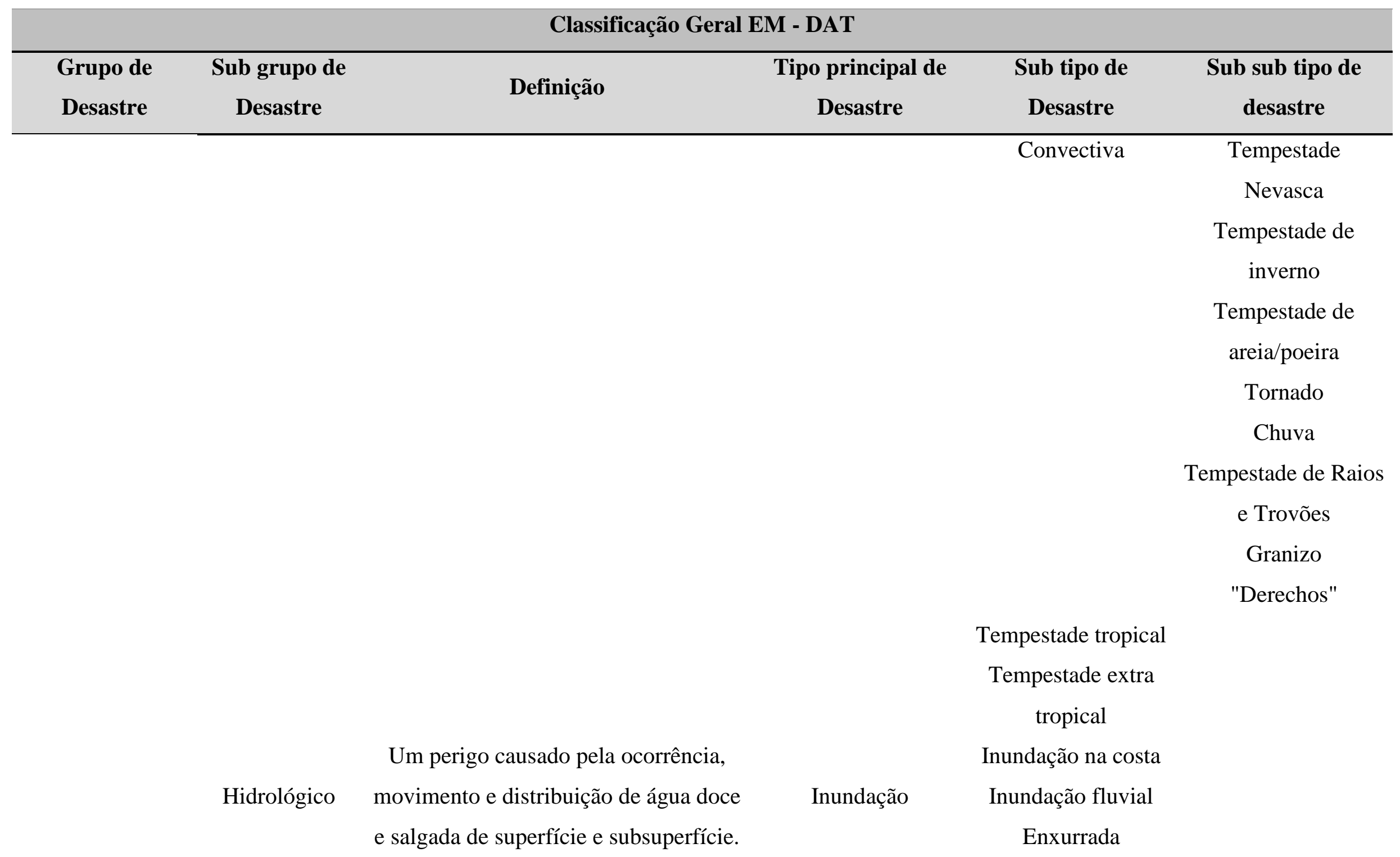




\section{Classificação Geral EM - DAT}

\begin{tabular}{cccccc}
\hline Grupo de & Sub grupo de & \multirow{2}{*}{ Definição } & Tipo principal de & Sub tipo de & Sub sub tipo de \\
Desastre & Desastre & & Desastre & Desastre & desastre
\end{tabular}

Inundação causada

por barreira de gelo

Avalanche (neves,

detritos, fluxo de

Deslizamento de

terra

lama,

desmoronamento de rochas)

Ação das ondas

Ondas em lagos

Ondas gigantes

\section{Seca}

Um perigo causado por processos atmosféricos de longa duração, da meso

Climatológico

para a macro escala, numa variabilidade

climática intra-sazonal para multi-

\section{decadal.}

Biológico
Um perigo causado pela exposição a organismos vivos e suas substâncias

\section{Derretimento de}

lagos glaciais

Incêndios em áreas

cultivadas

Incêndios na

floresta

Epidemias
Doença de Prião

Doença de Fungos 


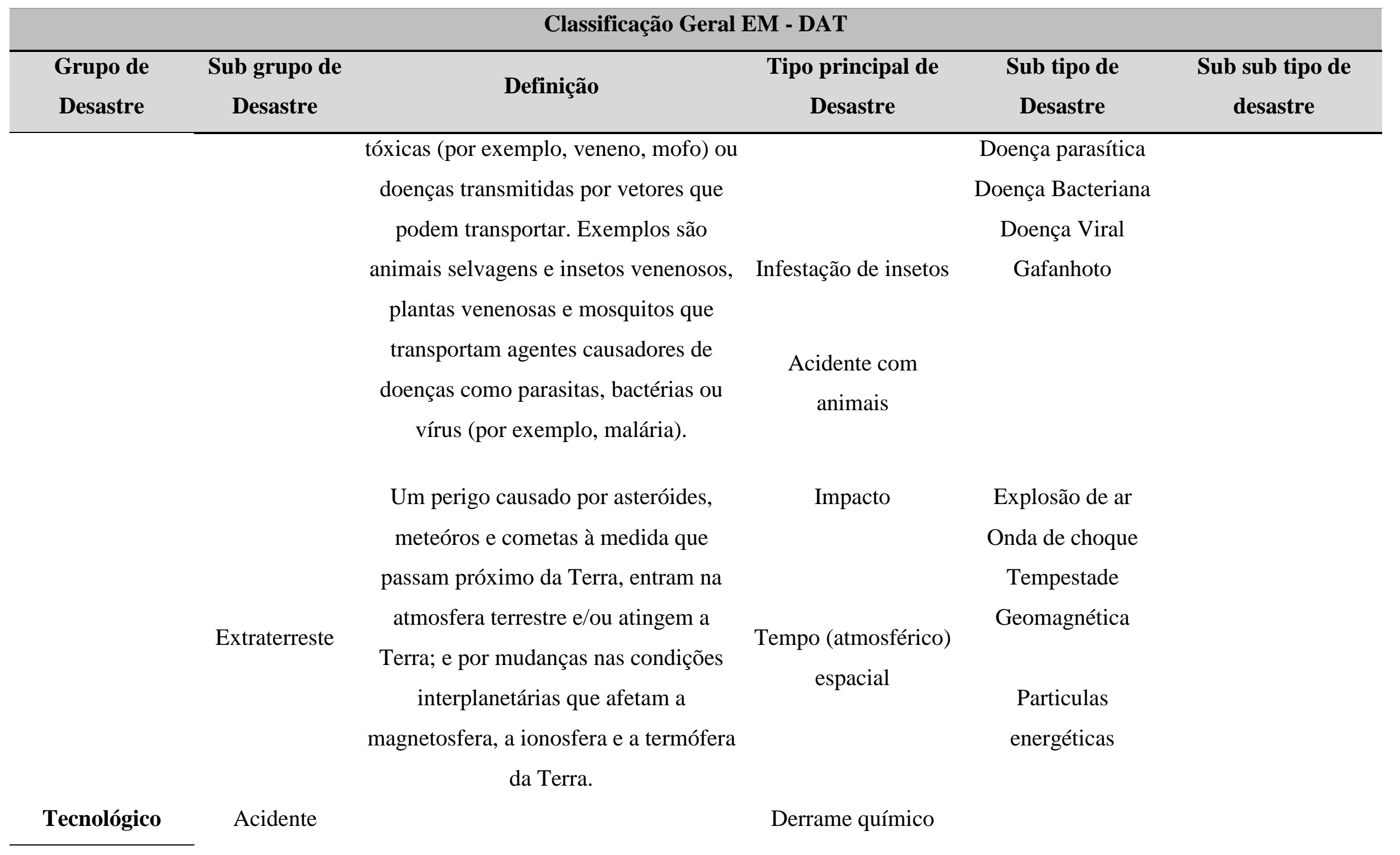




\section{Classificação Geral EM - DAT}

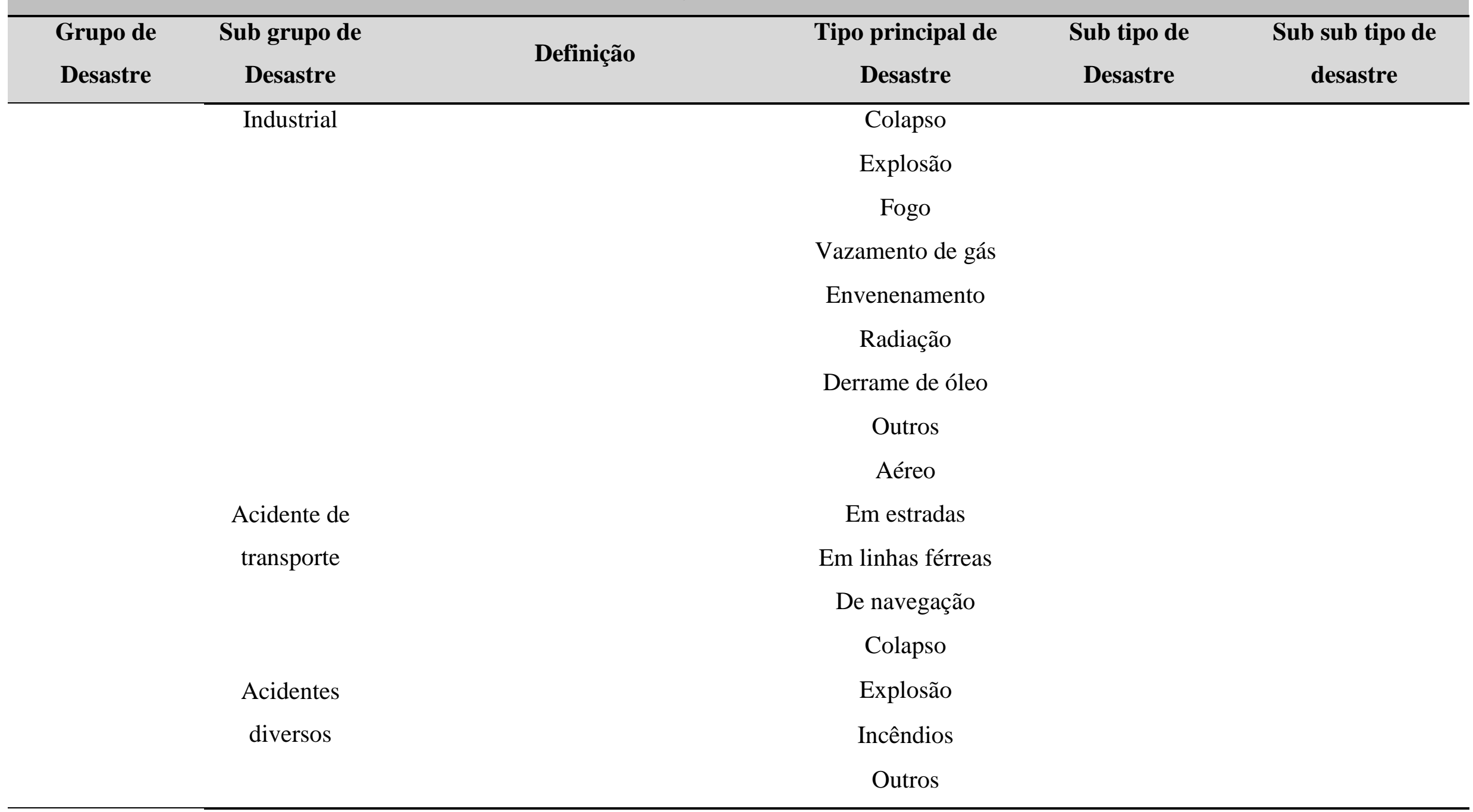




\section{ANEXO}

Quadro resumo com a classificação e a respectiva Codificação Brasileira de Desastres (COBRADE).

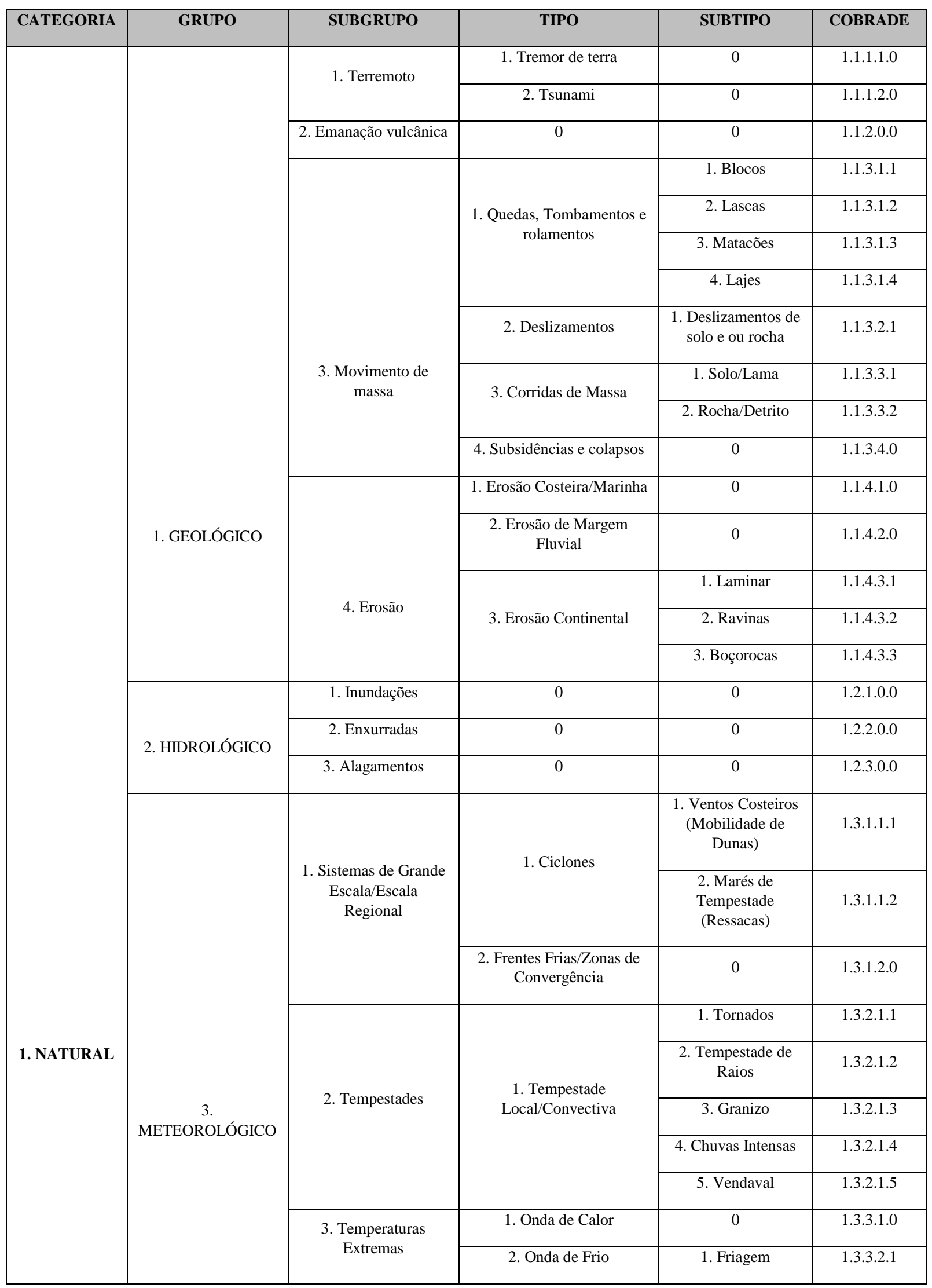




\begin{tabular}{|c|c|c|c|c|}
\hline & & & 2. Geadas & 1.3 .3 .2 .2 \\
\hline \multirow{5}{*}{$\begin{array}{c}4 . \\
\text { CLIMATOLÓGICO }\end{array}$} & \multirow{5}{*}{ 1. Seca } & 1. Estiagem & 0 & 1.4.1.1.0 \\
\hline & & 2. Seca & 0 & 1.4 .1 .2 .0 \\
\hline & & & $\begin{array}{c}\text { 1. Incêndios em } \\
\text { Parques, Áreas de } \\
\text { Proteção Ambiental } \\
\text { e Áreas de } \\
\text { Preservação } \\
\text { Permanente } \\
\text { Nacionais, } \\
\text { Estaduais ou } \\
\text { Municipais }\end{array}$ & 1.4.1.3.1 \\
\hline & & 3. Incêndio Florestal & $\begin{array}{l}\text { 2. Incêndios em } \\
\text { áreas não } \\
\text { protegidas, com } \\
\text { reflexos na } \\
\text { qualidade do ar }\end{array}$ & 1.4.1.3.2 \\
\hline & & 4. Baixa Humidade do Ar & 0 & 1.4.1.4.0 \\
\hline \multirow{8}{*}{ 5. BIOLÓGICO } & \multirow{4}{*}{ 1. Epidemias } & $\begin{array}{l}\text { 1. Doenças infecciosas } \\
\text { virais }\end{array}$ & 0 & 1.5.1.1.0 \\
\hline & & $\begin{array}{c}\text { 2. Doenças infecciosas } \\
\text { bacterianas }\end{array}$ & 0 & 1.5.1.2.0 \\
\hline & & $\begin{array}{l}\text { 3. Doenças infecciosas } \\
\text { parasíticas }\end{array}$ & 0 & 1.5.1.3.0 \\
\hline & & $\begin{array}{l}\text { 4. Doenças infecciosas } \\
\text { fúngicas }\end{array}$ & 0 & 1.5.1.4.0 \\
\hline & \multirow{4}{*}{ 2. Infestações/Pragas } & 1. Infestações de animais & 0 & 1.5 .2 .1 .0 \\
\hline & & \multirow{2}{*}{ 2. Infestações de algas } & 1. Marés vermelhas & 1.5 .2 .2 .1 \\
\hline & & & $\begin{array}{l}\text { 2. Ciano bactérias } \\
\text { em reservatórios }\end{array}$ & 1.5.2.2.2 \\
\hline & & 3. Outras Infestações & 0 & 1.5.2.3.0 \\
\hline
\end{tabular}

